\title{
The birds of Korup National Park and Korup Project Area, Southwest Province, Cameroon
}

\author{
PAUL G. RODEWALD, PIERRE-ANDRE DEJAIFVE and \\ ARTHUR A. GREEN
}

\section{Summary}

A total of 390 bird species are known to occur in the Korup National Park (KNP) and the surrounding Korup Project Area (KPA). Although the avifauna of KNP is incompletely known, it is already among the most ornithologically diverse lowland forest sites in Africa. The avian diversity of the KPA is increased by the montane forest bird species of the Rumpi Hills Forest Reserve (RHFR) and the Nta Ali Forest Reserve (NAFR). The lowland and montane forests of the KNP/KPA are very important to the conservation of African forest birds. Four species found in the Korup area are considered globally threatened, and four are considered near-threatened. In addition, 40 species were considered for threatened status, some of which are likely future additions to the threatened list. Twelve of Korup's 36 montane forest bird species are endemic to the montane areas of western Cameroon, eastern Nigeria, and Bioko (Fernando Po). The RHFR is especially important as a refuge for montane birds because much of the montane forest elsewhere in western Cameroon has been cleared for agriculture. Breeding phenology data are provided for many lowland forest species. Additionally, this report provides information on many rarely recorded species for western Cameroon, including several species not previously documented in the region. Kemp's Longbill Macrosphenus kempi was recorded for the first time in Cameroon. Because it is sympatric with the Yellow Longbill $M$. flavicans in Korup, additional evidence now exists for the contention that M. kempi and M. flavicans are separate species. The Yellow-chested Apalis Apalis flavida was also documented for the first time in Cameroon.

Un total de 390 espèces d'oiseaux existent dans le Parc National de Korup (KNP) et aux alentours de la Zone du Projet de Korup (KPA). Malgré le fait que l'avifaune dans KNP ne soit pas entièrement connue, ce parc est déjà l'un des sites forestiers de basse altitude ornithologiquement les plus diversifiés en Afrique. La diversité aviane de la KPA est encore augmentée par les espèces d'oiseaux des forêts de haute altitude dans la Réserve Forestière des Montagnes Rumpi (RHFR) et dans la Réserve Forestière Nta Ali (NAFR). Les forêts de basse et haute altitude du KNP et de la KPA sont très importantes pour la conservation des oiseaux forestiers africains. Quatres espèces trouvées dans la zone Korup sont considérées par BirdLife International (anciennement ICBP) et par l'Union Internationale pour la Conservation de la Nature (UICN) comme étant menacées au niveau mondial, et quatre autres espèces sont considérées comme étant quasi-menacées. De plus, le statut d'espèce menacée est envisagé pour 40 autres: certaines d'entre elles viendront probablement s'ajouter à la liste des espèces menacées. Douze (entre 36) espèces de la forêt de haute altitude Korup sont menacées sont endémiques aux zones forestières de l'ouest du Cameroun, de l'est du Nigéria, et de Bioko (Fernando Po). La RHFR est particulièrement importante comme refuge pour les oiseaux des montagnes, car la majeure partie des forêts de haute altitude à l'ouest du Cameroun a été détruite pour laisser place à l'agriculture. Des donnés sur la phénologie de la reproduction des 
oiseaux existent pour beaucoup d'espèces forestières de basse altitude. De plus, le rapport apporte des informations sur beaucoup d'espèces rarement observées dans l'ouest du Cameroun, y compris plusiers espèces qui n'avaient jamais été observées auparavant dans la région. Macrosphenus kempi a été observé pour la première fois au Cameroun. Etant donné que cette espèce est sympatrique avec $M$. flavicans dans la région du Korup, des preuves supplémentaires existent maintenant soutenant la thèse que $M$. kempi et $M$. flavicans sont deux espèces distinctes. L'espèce Apalis flavida a également été observée pour la première fois au Cameroun.

\section{Introduction}

The Korup National Park (KNP) is an area of lowland tropical forest in the Southwest Province of Cameroon which was created in 1986 by the government of Cameroon (Figure 1). Covering 124,000 ha, it is undoubtedly one of the most biologically significant forests in the whole of Africa. KNP is surrounded by the larger Korup Project Area (KPA), which extends south to the edge of mangrove forest bordering the Atlantic Ocean, and includes montane forest of the Rumpi Hills to the south-east of KNP (Figure 2). The Korup area contains an exceptional diversity of life, including a very high tree species diversity and 17 species of primates (Gartlan 1984) as well as 390 species of bird (this study).

This study spans a 36-month period from December 1990 to November 1993. The majority of the bird inventory work was conducted in KNP, but data are also provided from survey work in Rumpi Hills Forest Reserve (RHFR), and Nta Ali Forest Reserve (NAFR) within the surrounding KPA. These forest reserves were censused specifically to assess montane forest bird populations in KPA. Neither of these reserves had previously been surveyed by ornithologists. Many observations from the towns of Nguti and Mundemba are included. Bird species recorded by previous researchers in Korup, especially those of Thomas (1991, in press) and Agland (in Gartlan 1984) are provided.

Additional data from a mist-netting study of forest understorey birds conducted by P.A.D. and P.R. are included in this report. Valuable information was collected on breeding phenology and relative abundances of secretive understorey species. Breeding phenology data are presented with data summarized from Serle (1950, 1954, 1965, 1981). These data are significant in piecing together the natural histories of poorly known African forest birds.

The authors of this report worked in different parts of the KNP/KPA. P.R. researched Korup's birds from February 1991 through October 1992, focusing on the IRS in north of KNP. P.R. also conducted bird surveys in RHFR, NAFR, the south of KNP, and in the vicinities of the towns of Baro and Nguti. P.A.D.'s research was conducted from December 1990 to April 1991 and focused on the IRS and the north of KNP. He also worked extensively in the Baro area, and spent time in the south of KNP, near Mundemba. A.G.G. has been stationed in Mundemba since mid-1991 and has contributed observations from the south of KNP and KPA, including Mundemba.

In this report the following abbreviations are used: KNP, Korup National Park or "Park"; KPA, Korup Project Area or "Project Area" or "Korup area"; RHFR, Rumpi Hills Forest Reserve; NAFR, Nta Ali Forest Reserve; IRS, Ikenge Research Station; WCS, Wildlife Conservation Society; IUCN, International 


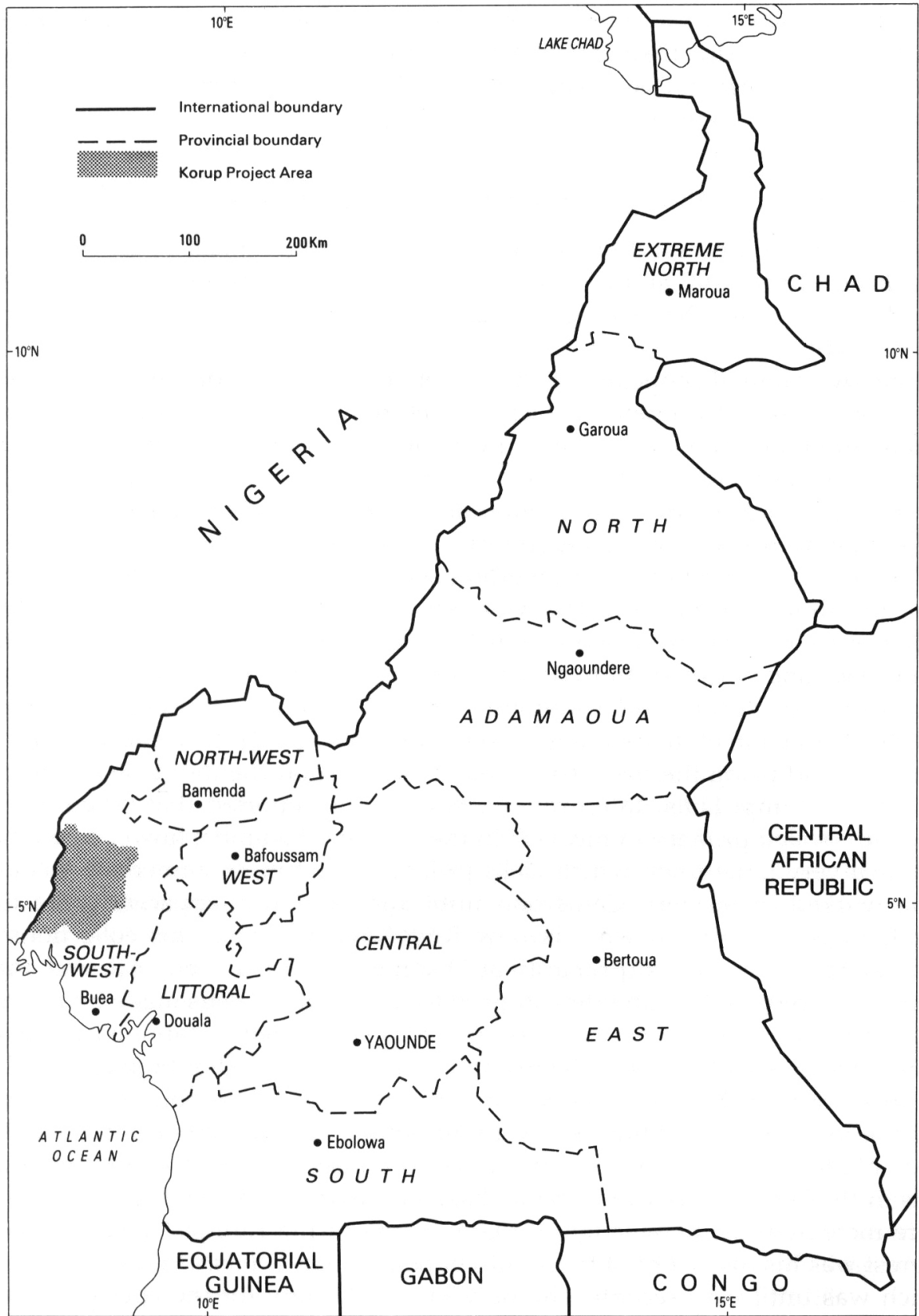

Figure 1. Provinces of Cameroon. (From Ministry of Plan and Regional Development, 1989.)

Union for Conservation of Nature and Natural Resources (the World Conservation Union); ICBP, International Council for Bird Preservation (now BirdLife International); WWF, World Wide Fund for Nature; RDB, Red Data Book (i.e. Collar and Stuart 1985). 
Observers have their names abbreviated as follows: P.A., Phil Agland; P.A.D., Pierre-André Dejaifve; A.A.G., Arthur A. Green; T.G., Tom Gullick; E.L., Evelyne Laurent; P.R., Paul G. Rodewald; P.S., Paul Smith; S.N.S., Simon Stuart; J.T., Jane Thomas.

\section{Brief history of ornithological research in the Korup area}

Although the Southwest Province of Cameroon (Figure 1) has a long ornithological history, the KNP and KPA have received little attention. In fact, the area of what is now the KNP was not visited by an ornithologist until the late 1950 s (Serle 1959).

As early as 1861 European ornithologists began visiting the southern part of Cameroon with Mt Cameroon, Limbe (Victoria) and Douala receiving a great deal of attention. The work of such explorers as Burton, Crossley, Preuss, Sjöstedt and Reichenow resulted in the discovery of several new bird species and subspecies. An extensive list of publications from these collections and other ornithological research in Cameroon can be found in Louette (1981a).

The Southwest Province of Cameroon seems to have received less attention from ornithologists in the early twentieth century until 1947, when William Serle began his extensive work which covered much of western Cameroon (Southwest and Northwest Provinces). Serle was based in Kumba and Bamenda (at least in part) and, among numerous contributions to African ornithology, had the distinction of discovering the endemic Mt Kupe Bush-shrike Malaconotus kupeensis, and being the first ornithologist to report on the montane forest species of the Rumpi Hills. Interestingly, Serle (1950) reported that "there is still much unspoiled primary rainforest" in the vicinity of Kumba; however, Kumba is now a very large town which lacks primary forest in its immediate vicinity. Serle worked in western Cameroon until 1957 and was apparently the first ornithologist to work in what is now KNP/KPA. He made his collections of birds in the Rumpi Hills (primarily at Dikome Balue) between 1949 and 1951. Serle (1959) reported on an interesting collection of birds' eggs made by Alastair Macdonald who between 1943 and 1956 was occasionally stationed at Ndian village, located south of Mundemba and adjacent to the KNP boundary.

Martin Eisentraut made a series of expeditions to Cameroon between 1938 and the late 1960s, resulting in several important detailed contributions to the study of montane fauna in western Cameroon. Eisentraut worked in the Rumpi Hills in the late 1960s and, like Serle, based himself in Dikome Balue. His work there increased our knowledge of the avifauna of the Rumpi Hills. Of special interest was his discovery of the White-naped Pigeon Columba albinucha in 1967, which was until very recently the only known locality for the species west of its range in eastern Zaire and western Uganda (Urban et al. 1986). It has now been observed at nearby Mt Kupe by Chris and Elizabeth Bowden (in litt. 1993).

In 1978 Jane Thomas began ornithological research in the southern part of what is now KNP. She reported on observations and mist-netting activities carried out between 1978 and 1989 (Thomas 1991) and compiled a list of 128 species that she documented inside KNP. In addition, she conducted surveys during boat trips made through the Rio del Rey, south of KNP and KPA (Thomas in press). 
In the 1980s Phil Agland, while working on a film of the flora and fauna of Korup entitled "Korup: an African rainforest", compiled a list of bird species encountered during his fieldwork in KNP. Gartlan (1984) published a bird species list for Korup which included Agland's records, and a few additional records not attributable to any particular observer. Nearly all records in this list were confirmed in our study, but a few questionable or unconfirmed records are not included here.

Other ornithologists visited the southern part of KNP for brief periods in the 1980s. Most notable was an ICBP team in 1984 which produced some valuable information (Stuart 1986). This team also visited Dikome Balue in the Rumpi Hills. Species lists for the park have subsequently been provided by Gullick (1987), Addison et al. (1988), Project Raleigh (Anon. 1989) and Smith et al. (1989).

\section{Study areas/survey locations}

Study areas were in the lowland and montane forests of KNP and KPA in the Southwest Province of Cameroon (Figure 1). Most research was conducted at Ikenge Research Station (IRS) in the northern part of KNP (Figure 2). The IRS is located approximately $3 \mathrm{~km}$ due east of the village of Ikenge on the east side of the Miri or Libangenie River $\left(5^{\circ} 16^{\prime} \mathrm{N} 9^{\circ} \mathrm{O} 7^{\prime} \mathrm{E}\right)$, at an elevation of approximately $240 \mathrm{~m}$. This river forms the western border of the primary research area of IRS $\left(\right.$ c. $14 \mathrm{~km}^{2}$ ). The area is bordered to the east by the Marube River, and extends roughly $2 \mathrm{~km}$ to the north and south of the research station.

The following other areas in the north of KNP were surveyed: selectively logged forest near Baro, farm/forest edge habitats of Baro and Ikenge villages, and forest between the IRS and KNP boundary at Baro. In addition, a one-week trip was made to the extreme north of KNP around the abandoned village of Bakumba, approximately $6 \mathrm{~km}$ north-west of Ikenge, and an area of primary forest approximately $5 \mathrm{~km}$ south-east of Esukutang.

Outside KNP in the north of KPA, village farms and logged forest around Nguti were surveyed. A three-day survey of NAFR was conducted in April 1992.

Forests of the southern part of KNP were surveyed, as were oil-palm plantations, village farms and logged forests in the vicinity of KNP and Mundemba. Additional observations were made on boat trips down the Ndian River from Mundemba.

In the south of the KPA outside KNP, three weeks were spent in November 1991 and March 1992 censusing birds in the Rumpi Hills. This work focused on the mountains of RHFR near Dikome Balue, and along the road leading north from Dikome Balue towards Madie-3, on the western border of RHFR.

A gazetteer giving coordinates and elevations for sites mentioned in the text is provided in Appendix 1.

\section{Topography of the study area}

The KNP and KPA encompass a varied topography which ranges from near sea-level in the extreme south of KPA to $1,768 \mathrm{~m}$ at the peak of Mt Rata in the Rumpi Hills. Much of KNP consists of rolling lowland forest, but in the centre 


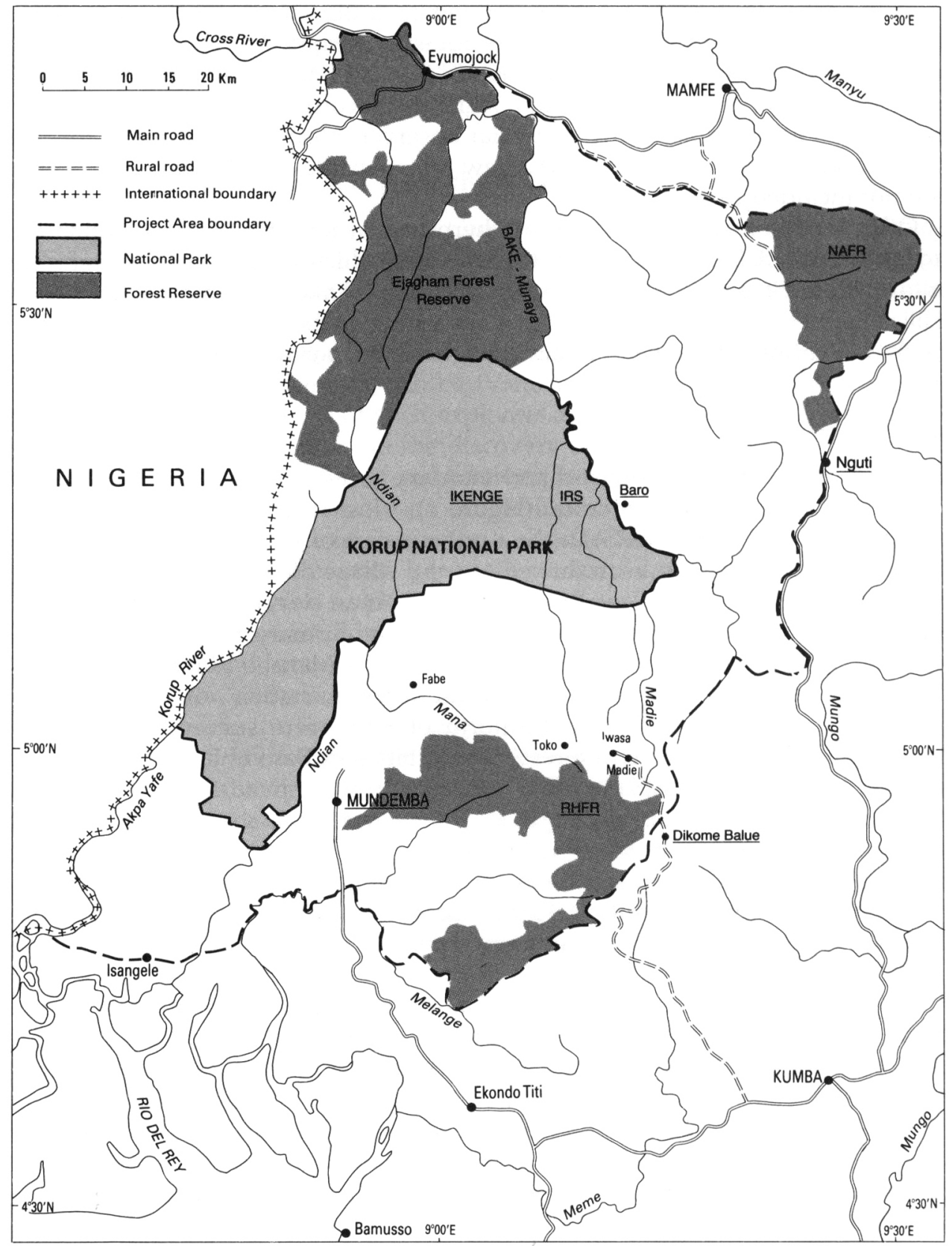

Figure 2. Korup National Park and Project Area. (From Ministry of Plan and Regional Development, 1989.)

near Ekundu Kundu and in the north-west around Bera and Esukutang the terrain is much steeper. The high point within KNP is Mt Yuhan, which rises to $1,079 \mathrm{~m}$. The Ministry of Plan and Regional Development (1989) states that $17 \%$ of KNP (21,000 ha) lies between sea level and $120 \mathrm{~m}, 40 \%(60,300 \mathrm{ha})$ is 
between 120 and $360 \mathrm{~m}, 33 \%(40,600 \mathrm{ha})$ is between $360 \mathrm{~m}$ and $850 \mathrm{~m}$, and $1 \%$ is between $850 \mathrm{~m}$ and $1,079 \mathrm{~m}$.

Much of the land in KPA is of similar nature to KNP, but a much greater proportion of this area is being used for agricultural purposes, and logging of forests has occurred in several locations. In the south of KPA the landscape is dominated by the Rumpi Hills, which lie about $50 \mathrm{~km}$ north of Mount Cameroon and cover an area roughly $50 \times 50 \mathrm{~km}$, part of which is contained in RHFR. The relief is very undulating with a number of peaks over $1,000 \mathrm{~m}$ and nine above $1,500 \mathrm{~m}$. Mount Rata is the highest peak at $1,768 \mathrm{~m}$, but it lies just outside the RHFR/KPA boundary near the village of Dikome Balue. The forest at the peaks support mainly lowland tree species, but several montane species such as Xylopia africana are found (Thomas 1986). In the north of KPA the major area of relief is the Nkwende Hills, between Nguti and Mamfe, which average from 400 to $700 \mathrm{~m}$, but include Mt Nta Ali at $1,266 \mathrm{~m}$. The NAFR is centred around this mountain, which lies in the north-east of KPA. The Ejagham Forest Reserve consists of lowland forest similar to KNP

The north-east of KNP and much of the northern half of KPA are drained by the Bake-Munaya River, which flows northward to the Cross River (Figure 2). The headwaters of this system extend southward to the north-eastern part of the Rumpi Hills. The Ndian River drains the central region of KNP and the western slopes of the Rumpi Hills and flows south to the Atlantic Ocean. The south-western region of KNP drains into the Korup River, which also flows south to the Atlantic. This river forms the western border of KNP and part of Cameroon's border with Nigeria.

\section{Climate of the study area}

The climate of Korup is characterized by a wet season lasting from March through November with the months at the extremes being somewhat variable in their amount of rainfall. The dry season typically runs from December to February, but brief storms can occur in any month. In addition, the dry season seems to end earlier in the south of Korup than in the north.

Mean monthly rainfall amounts within KPA ranged from a low of $5 \mathrm{~mm}$ in January at IRS to a high of $952 \mathrm{~mm}$ at Ndian (Table 1). Total annual rainfall decreased with increasing latitude in KPA (Ministry of Plan and Regional Development 1989, WCS unpublished data). Additionally, mean annual rainfall over a two-year period differed by approximately $1,500 \mathrm{~mm}$ between the IRS and Nguti, despite the two sites being separated by only $33 \mathrm{~km}$.

At IRS the mean annual temperatures ranged between $21.7^{\circ} \mathrm{C}$ and $27.7^{\circ} \mathrm{C}$ during 1990 and 1991. In Nguti mean annual minimum and maximum temperatures ranged from $23.0^{\circ} \mathrm{C}$ to $32.6^{\circ} \mathrm{C}$ respectively, from September 1991 to August 1992. Although these data represent a brief period of time, the large difference in the annual average temperatures for Nguti and IRS is evident. The relatively cooler temperatures at IRS demonstrate the cooling effect of the primary forest. Temperature data collected in a 27 -month period at IRS showed a mean monthly low temperature of $17.5^{\circ} \mathrm{C}$ in January 1992 and a high of $33.2{ }^{\circ} \mathrm{C}$ in March 1992. In 14 years of data from Ndian, the lowest mean monthly temperature occurred in January $1983\left(20.0^{\circ} \mathrm{C}\right)$ while the highest was in March 1983 
Table 1. Mean monthly and annual rainfall $(\mathrm{mm})$ at selected locations in the Southwest Province of Cameroon

\begin{tabular}{lrrrrrr}
\hline & Ndian & Kumba & $\begin{array}{c}\text { Dikome } \\
\text { Balue }\end{array}$ & Rio del Rey & Nguti & $\begin{array}{c}\text { Ikenge } \\
\text { Research } \\
\text { Station }\end{array}$ \\
\hline January & 40 & 17 & 11 & 90 & 30 & 5 \\
February & 127 & 70 & 196 & 134 & 90 & 20 \\
March & 258 & 197 & 374 & 93 & 120 & 90 \\
April & 300 & 206 & 342 & 261 & 395 & 245 \\
May & 395 & 194 & 307 & 358 & 380 & 225 \\
June & 715 & 225 & 397 & 523 & 415 & 190 \\
July & 887 & 276 & 757 & 1,032 & 620 & 310 \\
August & 952 & 335 & 975 & 951 & 560 & 280 \\
September & 752 & 390 & 801 & 712 & 525 & 340 \\
October & 544 & 264 & 380 & 531 & 390 & 360 \\
November & 319 & 78 & 231 & 160 & 170 & 140 \\
December & 93 & 46 & 60 & 52 & 30 & 15 \\
Total mm & 5,382 & 2,298 & 4,933 & 4,896 & 3,725 & 2,220 \\
Years & 14 & 7 & 2 & $?$ & 2 & 2 \\
\hline
\end{tabular}

Sources: Ministry of Plan and Regional Development 1989 (Ndian, Kumba and Dikome Balue); Suchel (1972) (Rio del Rey); WCS-Korup (unpublished data) (Nguti and Ikenge Research Station).

$\left(34.7^{\circ} \mathrm{C}\right)$. Additional information on the climate of the KPA can be found in the Korup Project Master Plan (Ministry of Plan and Regional Development 1989).

\section{Methods}

Owing to the difficulty in censusing birds effectively in tropical forests (for a review see Karr 1981), conventional bird survey techniques were not used in this study. Instead, surveys involved simply recording numbers of each bird species observed and/or heard each day spent in the field. These surveys were conducted between December 1990 and October 1992 by P.A.D. and P.R. Forest understorey species were censused with mist-nets. Many casual observations were made and these are included in this report. In addition, some bird vocalizations were tape-recorded for later analysis. We believe the combination of these methods was fairly accurate in assessing the relative abundances of bird species.

To detect secretive ground-dwelling and understorey birds, mist-nets measuring $12 \times 2.5 \mathrm{~m}$ were placed at ground height. Birds were mist-netted in most locations surveyed (Figure 2), including the IRS, two locations north of IRS, two locations near Baro, Nguti, RHFR, and the south of KNP at the tourist camp closest to the KNP entrance. At IRS a grid system of transects measuring $2 \times 1.5 \mathrm{~km}$ was used for mist-netting activities and surveys. A total of approximately 5,200 net hours were accumulated during a 21-month period. Complete biometrics and information on breeding status were taken. Only birds with active brood-patches were considered to be breeding. Birds captured at IRS and at two sites near Baro were banded with aluminium leg bands or plastic colour bands. Over 700 were banded at IRS and 200 at the Baro locations.

Elevational ranges were recorded for bird species surveyed in RHFR and NAFR. Estimates of altitude for sightings were determined with an altimeter 
and a topographic map. All observations in RHFR were made between 1,000 and $1,768 \mathrm{~m}$ in altitude; NAFR observations were made between the base of the reserve near Nfainchang $(240 \mathrm{~m})$ and the $1,266 \mathrm{~m}$ summit of $\mathrm{Mt} \mathrm{Nta}$ Ali.

The taxonomy and sequence of families and species for non-passerine birds through the majority of the Turdinae (thrushes) is based on Birds of Africa (Brown et al. 1982, Urban et al. 1986, Fry et al. 1988, Keith et al. 1992). For the remainder of the passerine birds, taxonomy follows that of Louette (1981a), a slightly revised form of White (1960, 1962a, 1962b, 1963) and Morony et al. (1975). Subspecies are mentioned in the species accounts when appropriate.

Finally, it is necessary to clarify the area which we consider "KNP" for listing purposes. By an arbitrary decision, all bird species recorded within a $5 \mathrm{~km}$ band around KNP are counted below as KNP species, but this is not judged to have raised the total number of species in the park, merely to have provided a more accurate indication of that number. Birds mentioned as occurring in "KNP/KPA" have been recorded in both KNP and KPA. In addition, when the terms "Korup" or "Korup area" are used they refer specifically to KNP/KPA. When "park" is used it refers to KNP.

\section{Codes and notes for the annotated list of species}

A compilation of species accounts of birds recorded in KNP and KPA follows. For a number of species, especially rarely recorded ones, few data are reported except for location and habitat information regarding the sighting. The first set of accounts covers species of birds known from KNP. These accounts also include information on the species' abundance elsewhere in the KPA. Next, accounts of species recorded in KPA (e.g. RHFR, NAFR), but which are (as yet) unknown from KNP, are provided. A list of hypothetical species for KNP and $\mathrm{KPA}$ is given in Appendix 2.

A system of codes is used to describe the status, abundance and location of sightings within KNP/KPA. After the common and scientific names for a species, codes for status, abundance and location respectively, are given; these refer only to the status and distribution of species in KNP, and are explained as follows.

Habitat:

* lowland forest specialist

$+\quad$ montane forest specialist

Status:

RS resident (species is non-migratory)

PM Palearctic migrant (species migrates to the tropics for the boreal winter)

AM intra-African migrant (species makes major migrations within Africa)

LM local migrant (species migrates or moves locally)

? status of the species is unknown or uncertain

Abundance:

$r \quad$ rare (few records)

u uncommon (seen infrequently)

f frequent (seen often, but not every day)

c common (1-10 seen/heard daily) 
a abundant (10-100 seen/heard daily)

v very abundant (more than too seen/heard daily)

d abundance debatable

Location:

(N) northern Korup National Park

(S) southern Korup National Park (including Mundemba)

Many species do not fall neatly into the above categories. For some, there is simply not enough known about migratory patterns, making it difficult to assign a status code. In such cases two status codes or a "?" are given. It is important to note that abundance codes refer to the frequency a species was recorded during the study and not necessarily to its actual abundance. For example, a species which has only been recorded a few times would be listed as "rare" even though it may not actually be rare in the area. Finally, the abundance code refers to the abundance of a species in its favoured habitat.

The names of observers are listed chronologically or nearly so for each species. In cases where a species has been recorded by more than five observers or groups, individual observers are not listed; but observers are listed for all KNP species. In general, records from credible observers of species which are expected to occur in Korup have been accepted. However, for certain species it would be desirable to have further documentation of their occurrence in Korup. These species are noted in the species accounts.

Breeding phenology data are given for birds of KNP/KPA, most notably the passerines. These data come primarily from mist-netting studies conducted at IRS and near Baro in the north of KNP. To supplement our findings, data from Southwest Province, Cameroon, provided by Serle $(1950,1954,1965,1981)$ and Dejaifve (1991) have also been included. A few breeding records are provided from work conducted in the montane forests of RHFR and NAFR. However, data for lowland species breeding in montane areas are not compared with breeding records from lowland sites. Tye (1992) has shown that there is a reversal in the breeding season for lowland birds breeding in Cameroon montane forests.

\section{Bird species from Korup National Park and Project Area}

Little Grebe Tachybaptus ruficollis: RS/LM, $r(N), u(S)$. There is one record of this unobtrusive species from the north of KNP (T. Hart in Dejaifve 1991), and Thomas (1991) states that it was seen on occasion in forest pools in the south of KNP, where it is probably commoner. It favours slow-moving or still waters. P.R. recorded it in RHFR. Serle (1981) implied that it moves locally in the dry season, as it can be found in unlikely breeding localities during this period. Observers: J.T., T. Hart, P.R.

Long-tailed Cormorant Phalacrocorax africanus: RS/LM, $f(S)$. This species is found on larger, more open rivers in the south of KNP/KPA. It has yet to be recorded in the north of the KPA, but probably occurs in small numbers. In Nigeria Elgood (1982) considered it to undergo local movements in response to changing river water levels, and this is probably the case in the Korup area as well. In 
Korup it is seen primarily in the dry season, but it was recorded throughout the year in western Cameroon (Northwest and Southwest Provinces) by Serle (1965). Observers: P.A., P.S. and co-workers, P.A.D., A.A.G., P.R.

Darter Anhinga melanogaster: RS/LM, r(S). Currently known only from the south of KNP. It is found along the larger rivers of the area such as the Ndian, where it is uncommon. Thomas (in press) recorded it on six of nine boat trips through the mangroves just south of KNP/KPA. It probably makes local movements in response to changing river water levels. Observer: P.A., A.A.G.

Dwarf Bittern Ixobrychus sturmii: RS, $\mathrm{r}(\mathrm{S})$. The only record of this species for KNP/KPA was on 9 December 1991 in the south of KNP near Mundemba. As this is a secretive species it is possible that it is simply overlooked. Observer: A.A.G.

White-crested Tiger-heron Tigriornis leucolophus*: RS, r(N), u(S); RDB candidate. A species of forested streams and rivers, swampy areas, and mangroves. Owing to its secretive nature it may be more frequent in the north than indicated. P.A.D. found that it is commonest in the mangroves near the southern periphery of the KPA. Observers: many.

Black-crowned Night-heron Nycticorax nycticorax: PM, r(S). A Palearctic migrant which has been reported by only one observer in KNP. Future work may prove it to be more regular during the dry season when it is present in Cameroon. Observer: P.A.

Squacco Heron Ardeola ralloides: PM, f(S). A Palearctic migrant which is present in Cameroon from October through April (Louette 1981a). Only known in the Korup area from November through April, and all records so far are from the south of KNP/KPA. Observers: P.A., P.S. and co-workers, P.A.D., A.A.G., P.R.

Cattle Egret Bubulcus ibis: AM, $\mathrm{u}(\mathrm{N}), \mathrm{c} / \mathrm{a}(\mathrm{S})$. This intra-African migrant is known from agricultural areas and villages throughout KNP/KPA, primarily from October to May. A.A.G. recorded seven birds near Mundemba on 5 June 1992, and a lone bird on 6 September 1992 in the same location. Although these were probably late and early migrants respectively, Serle (1965) recorded birds on occasion throughout the rainy season at Limbe, and A.A.G. found flocks there in July and August 1993. During the peak of the wet season the species breeds in the Sahel (Louette 1981a). Observers: many.

Green-backed Heron Butorides striatus ${ }^{*}: R S, r / u(N), u(S)$. Not often encountered in the north of KNP/KPA, and Dejaifve (1991) found it to be commoner in the south. It is probably commonest in the mangroves just south of the KPA, but it can also be found along rivers and in swamps. Observers: many.

Little Egret Egretta garzetta: RS/PM, f(S). Recorded so far only from the south of KNP/KPA, though it should occur in the north. A.A.G. found it to be frequent throughout the year in oil-palm plantations near Mundemba, along the Mana 
River and in the mangroves. Hence at least part of the population in this area is resident. It is not known how significant the influx of Palearctic migrants is in the dry season. Observers: P.A., P.A.D., P.R., A.A.G.

Great Egret Egretta alba: RS, $\mathrm{f}(\mathrm{S})$. A species known only in the south of KNP/KPA, although it should occur in the north of the KPA outside KNP. A.A.G. finds it frequent near Mundemba in oil-palm plantations, and along the Mana and Ndian Rivers in all months except September and October, when it is absent. Observers: P.A., P.R., A.A.G.

Purple Heron Ardea purpurea: PM, r(N), r(S). There are currently very few records of this Palearctic migrant species in KNP/KPA. P.A.D. recorded it in KNP in March 1991 and A.A.G. found it there in December 1991, March and April 1993 and November 1993 near Mundemba. Thomas (in press) recorded it in December and April of 1978 in the Rio del Rey south of KNP/KPA. Serle (1965) had only one sight record from the Southwest Province. Observers: P.A., P.A.D., A.A.G.

Grey Heron Ardea cinerea: RS/PM, $r(N), f(S)$. In the south of KNP/KPA this species is frequent throughout the year and is commoner during the rainy season. There are few records in the north of KNP/KPA, but it is probably more widespread than records suggest. Observers: P.A., P.S. and co-workers, P.A.D., A.A.G., P.R.

Black-headed Heron Ardea melanocephala: AM, r(N), u(S). An intra-African migrant for which there are few records in the north of KNP/KPA, more in the south, although A.A.G. still considers it uncommon in the south. Serle (1965) recorded the species in western Cameroon (Southwest and Northwest Provinces) from October to April. Observers: P.A., P.A.D., A.A.G., P.R.

Hamerkop Scopus umbretta: RS, $f(S)$. This species is fairly common along rivers in the southern part of KNP/KPA, where A.A.G. found it throughout the year. This is contrary to Louette (1981a), who states that the subspecies S. u. minor found in the south-west of Cameroon is present from January to June and then leaves Cameroon towards the west. P.R. recorded it only once in the north of the KPA at Nguti. Observers: P.A., J.T., P.A.D., A.A.G., P.R.

Yellow-billed Stork Mycteria ibis: AM, r(S). There are few records of this intraAfrican migrant in KNP/KPA. P.A. recorded it soaring over forest in the south of KNP. It should be looked for in the wet season when it is present in the south of Cameroon; it breeds during the dry season in the north of the country (Louette 1981a). Observer: P.A.

African Open-bill Stork Anastomus lamelligerus: AM, r(S). This intra-African migrant was recorded by P.A. soaring above forest in the south of Korup. Serle (1950) reported only one sighting of five individuals on a lake near Kumba and concluded that the species is rare within the forest zone. However, it is commoner in mangroves and estuaries at the coast (Louette 1981a). Thomas (in 
press) recorded the species in the Rio del Rey, just south of the KPA. Observer: P.A.

Woolly-necked Stork Ciconia episcopus: RS/AM, r(N), f(S). Louette (1981a) states that this species leaves the south of Cameroon after the dry season to breed north of $12^{\circ} \mathrm{N}$. However, Serle (1965) reported the species throughout the year at a number of localities in the Southwest Province, including Ndian. The data from A.A.G. in the south of KNP also support this finding. Records from the north of the KPA are few. Additional records of the species come from the Rumpi Hills (Stuart 1986). Observers: P.A., J.T., P.A.D., A.A.G., P.R.

Hadada Bostrychia hagedash*: RS, r(N), u/f(S). A.A.G. has observed the species along the Mana, Korup, and Oweyé Rivers in the south of KNP/KPA and considers it uncommon there. It has so far been recorded primarily in the southern part of KNP/KPA along larger rivers. Observers: J.T., P.A., P.A.D., A.A.G., P.R.

Spot-breasted Ibis Bostrychia rara*: RS, u(N), r(S); RDB candidate. P.A.D. considered this ibis uncommon and encountered it more frequently than $B$. hagedash. It is found in swamp forest. Observers: P.A., P.A.D.

Sacred Ibis Threskiornis aethiopica: AM, $\mathrm{r}(\mathrm{S})$. Observed by P.A. soaring over primary forest in the south of KNP, and recorded several times in the dry seasons of 1978-1979 by Thomas (in press) in the Rio del Rey just south of KNP/KPA. Observer: P.A.

Hartlaub's Duck Pteronetta hartlaubii*: RS, u/f(N), u(S). This forest species is found on slow-moving rivers, streams and backwaters in KNP/KPA. It can be regularly observed in its proper habitat, but this is limited in some areas. Observers: J.T., P.A., P.A.D., A.A.G., P.R.

Osprey Pandion haliaetus: $\mathrm{PM}, \mathrm{r}(\mathrm{S})$. This migratory raptor breeds in the Palearctic and is typically present in Cameroon from September to March (Louette 1981a). However, there are both wet and dry season breeding records for south-western Cameroon. The wet season records are from Cape Debundscha on 26 June 1957 and Limbe on 3 July 1957 (Serle 1965). Breeding reports are of an Osprey carrying nest material on 16 December 1947 at Ndian (KNP boundary), and another bird seen at a nest on an island in Ambas Bay near Limbe on 28 June 1948 (Serle 1965); but Brown et al. (1982) reject breeding records south of $14^{\circ} \mathrm{N}$. In KNP/KPA it has been recorded on the Ndian River which borders the southern part of KNP. It will probably be discovered elsewhere in the KPA along larger rivers and perhaps at Ejagham Lake. Observers: J.T., Macdonald (in Serle 1965).

Cuckoo Falcon Aviceda cuculoides*: RS, u(N), r(S). Observed rather infrequently in KNP/KPA, known from RHFR, the north of KNP (near Baro and around Ikenge village), and the south of KNP. In May and June 1992 P.R. observed a pair regularly bringing food to a nest in a large, mainly leafless tree in logged forest near Baro village. Observers: P.A., P.A.D., P.R. 
European Honey-buzzard Pernis apivorus: PM, r(N), r(S). Louette (1981a) states that this species is present in the forest of Cameroon from November to March, but there are few records within KNP/KPA to date. P.A. noted it in the canopy of forest in the south of KNP on roughly six occasions. P.A.D. saw an individual several times in farms near Ikenge village in January 1991. Serle (1954) recorded it in forest clearings around Kumba during the dry season, but not annually. Observers: P.A., P.A.D.

Bat Hawk Machaerhamphus alcinus*: RS, $r(N)$. The only record for KNP/KPA was from IRS on 17 November 1991 where one individual was circling over a small clearing in primary forest. The species may have been overlooked, given its crepuscular habits. P.A.D. recorded it near Limbe in early April 1991. Observer: P.R.

Black-shouldered Kite Elanus caeruleus: RS/LM, r(S). Only one observation has been made for KNP. A bird was observed on 29 September 1992 circling over forest edge near Mundemba. It has not been recorded elsewhere in the KPA, but should occur in open habitats outside the forest. Observer: P.R.

Black Kite Milvus migrans: AM, c(N), c/a(S), September-June. A common to abundant species around villages, towns and other open areas. P.R. observed it flying high above primary forest, as did Thomas (1991). It breeds in the Korup area during the dry season and then migrates northward before the peak of the rains (Louette 1981a). P.A.D. witnessed a copulation in mid-January and nest-building in mid-March. Observers: many.

African Fish-eagle Haliaeetus vocifer: $\mathrm{RS}, \mathrm{u}(\mathrm{S})$. Few records from KNP/KPA exist. Thomas (in press) recorded it on several boat trips through the Rio del Rey estuary in 1979. A.A.G. recorded birds at least twice during April and May 1991 along the Mana River near Mundemba. It is also found at Lake Ejagham in the extreme north of the KPA (F. Nkongho in litt. 1992). Observer: P.A., J.T., A.A.G.

Palm-nut Vulture Gypohierax angolensis*: RS, $f(N), c(S)$. A common species in the southern part of KNP/KPA in oil-palm plantations, farms, along rivers and, less commonly, in primary forest. In the north of KNP/KPA and in RHFR above $1,000 \mathrm{~m}$ it is much less common. Observers: many.

Congo Serpent-eagle Dryotriorchis spectabilis*: RS, r(N); RDB candidate. This lowland forest species was observed in the village of Baro in July 1992, currently the only record for KNP/KPA, and one of very few for western Cameroon. Observer: P.R.

African Harrier-hawk Polyboroides typus*: RS, c(N), c(S). A common raptor throughout KNP/KPA especially in farm-bush, villages, plantations and edge habitats. Observers: many. 
Marsh Harrier Circus aeruginosus: PM, r(S). There are a few dry season records of this Palearctic migrant raptor from the south of KNP/KPA. An individual was observed on 21 March 1991 in a cut-over palm plantation near Mundemba by P.A.D., P.R. and E.L. A.A.G. observed a bird near the Mana River bridge (southern KNP entrance) on 6 January 1993, an adult male near Ekondo Titi (outside the KPA) in late January 1992, and a male in the plantation near Mundemba on 20 March 1993. Observers: P.A.D., A.A.G., P.R.

African Goshawk Accipiter tachiro*: RS, $\mathrm{u}(\mathrm{S}) \mathrm{u}(\mathrm{N})$. This forest hawk is found in forest edge and primary forest and is known from both the north and south of KNP/KPA. Louette (1981a) suggests that there could be a broad belt of intermediates in Cameroon, but only $A$. $t$. macroscelides has been recorded with certainty in Korup. Observers: P.A., A.A.G., P.R.

Chestnut-flanked Goshawk Accipiter castanilius*: RS, r(N), r(S). Rarely recorded in KNP/KPA, the species may be overlooked given the difficulty in observing accipiters in the forest. One flew into a mist-net in the south of KNP in March 1991 (P.A.D., P.R. and E.L.). A.A.G. observed the species outside KNP, south of Mundemba, on 26 August 1992. Ash et al. (1989) recorded it once in the Ikpan block of Cross River National Park, Nigeria, adjacent to Korup. Observers: P.A., P.A.D., E.L., P.R., A.A.G.

Red-thighed Sparrowhawk Accipiter erythropus*: RS, r(N), r(S). A rarely reported forest accipiter in KNP/KPA. P.A.D. and P.R. each recorded the species in the vicinity of Baro in the north of the KNP, and P.R. recorded it once at Nguti. Observers: P.A., P.A.D., P.R.

Great Sparrowhawk Accipiter melanoleucus*: RS, $\mathrm{u}(\mathrm{N}), \mathrm{u}(\mathrm{S})$. There are several reports for KNP/KPA. P.R. recorded it six times during 1992 in the north of KNP/KPA at NAFR, Baro, Nguti, and IRS. A.A.G. has recorded it on three occasions in the Mundemba area. Observers: A.A.G., P.R.

Long-tailed Hawk Urotriorchis macrourus*: RS, r/u(N), r/u(S); RDB candidate. A rare to uncommon raptor in primary and secondary forest of the Korup area. There are observations from the north and south of the KNP and also from the Nguti area. Observers: J.T., P.A., A.A.G., P.R.

Lizard Buzzard Kaupifalco monogrammicus: $R S, u / f(N), u / f(S)$. A raptor found in forest edge, villages and other open areas in KNP/KPA which is absent from primary forest. Recorded at Nguti, Baro, RHFR and Mundemba. Observers: P.A., P.A.D., A.A.G., P.R.

Red-necked Buzzard Buteo auguralis: AM, $\mathrm{r}(\mathrm{N})$. The one record of this migratory raptor in KNP comes from Baro where P.R. observed it in March 1992. Records from the KPA, outside KNP, come from Dikome Balue in the Rumpi Hills, and Nguti where it is uncommon to frequent. Serle (1965) reports that the species is absent in western Cameroon from mid-June to mid-September. Nesting in the Korup area is possible, as Serle (1950) observed three cliff nests near Mt 
Manenguba in March 1948 some $30 \mathrm{~km}$ east of the KPA. The species is found in open habitats, outside primary forest. Observer: P.R.

Long-crested Eagle Lophaetus occipitalis: RS, $\mathrm{u}(\mathrm{N}), \mathrm{u}(\mathrm{S})$. This species is often seen perched on large dead trees in open areas. It has been recorded in a number of places in KNP/KPA, including RHFR, Nguti and both the north and south of KNP. Observers: P.S. and co-workers, P.A.D., A.A.G., P.R.

Cassin's Hawk-eagle Spizaetus africanus*: RS, r(S); RDB candidate. This forest species is known only from the south of KNP and from RHFR. It has not been observed in the north of KNP/KPA, although it should occur. Observers: P.A., T.G., P.S. and co-workers, A.A.G., P.R.

Crowned Hawk-eagle Stephanoaetus coronatus*: RS, $u(N), u(S)$. A forest species which was also seen flying over secondary habitats. It has been recorded in the north and south of KNP/KPA, and in RHFR. Observers: many.

Black Guineafowl Agelastes niger*: RS, $\mathbf{u} / \mathrm{f}(\mathrm{N}), \mathrm{u} / \mathrm{f}(\mathrm{S}) ; \mathrm{RDB}$ candidate. Found in primary forest and selectively logged forests near Baro village. Although fairly common, it can be difficult to observe. It may be commoner in the south of KNP, as Thomas (1991) reported seeing birds up to three times in one week. Observers: J.T., P.A., P.A.D., A.A.G., P.R.

Crested Guineafowl Guttera pucherani*: RS, $u / f(N), u / f(S)$. A bird of primary and logged forest in KNP/KPA which has been noted in the north and south of KNP and at Baro village. Observers: P.A., P.A.D., A.A.G., P.R.

Latham's Forest Francolin Francolinus lathami*: RS, $f(N), f(S)$. A fairly common, but discreet, forest species of the north and south of KNP. P.R. captured one member of a small covey in a mist-net south-east of Esukutang in the north of KNP. Observers: P.A., T.G., P.A.D., A.A.G., P.R.

Scaly Francolin Francolinus squamatus*: RS, $f(N), f(S)$. A common species throughout $\mathrm{KNP} / \mathrm{KPA}$ in farms and around villages, but absent from primary forest. P.A.D. did not record it around Ikenge village, perhaps owing to the small size of the village and its isolation within primary forest. P.A.D. and P.R. observed a group with at least two juveniles in early April 1991 near Kumba. Observers: P.A., P.A.D., A.A.G., P.R.

Nkulengu Rail Himantornis haematopus*: RS, $\mathrm{u} / \mathrm{f}(\mathrm{N}), \mathrm{f}(\mathrm{S})$. This species seems somewhat thinly distributed in KNP/KPA, but it is regularly heard where present. It is found along streams in lowland forest. Observers: many.

Grey-throated Rail Canirallus oculeus*: RS, r(S). Serle (1959) described the nest and eggs of this forest rail, which were found near Ndian at the border of the southern part of KNP. This record, along with those in Bannerman (1931) and Eisentraut (1963) from the Mt Cameroon area, are apparently the only for Southwest Province. It is possible that the species is more frequent in seasonally 
flooded forests along rivers in the south of KNP/KPA (F. Dowsett-Lemaire in litt. 1993). Observer: Macdonald (in Serle 1959).

White-spotted Flufftail Sarothrura pulchra*: RS, c(N), c(S). In KNP/KPA this species is widespread and common in primary, secondary and logged forests, and village farms. It seems to have a preference for forest streams and swampy areas, but was found regularly in upland habitats. Its year-round song is among the most commonly heard vocalizations in Korup. In RHFR the species was recorded by P.R. up to $1,500 \mathrm{~m}$. Observers: many.

African Crake Crex egregia: RS/AM, $r(N), u / f(S)$. This species has been recorded in KNP/KPA in almost every month of the year, and it seems that some birds must be resident. However, birds probably move locally in response to water availability. In June, when the species seems commonest, A.A.G. has observed up to 12 birds in an $8 \mathrm{~km}$ passage through replanted oil-palm stands near Mundemba. These crakes are least common near Mundemba during December-April. It is probable that many leave the area during the dry season for other, damper areas. Observers: P.S. and co-workers, A.A.G., P.R.

Black Crake Amaurornis flavirostris: RS, r(S). Three individuals were observed on 30 September 1992 foraging in a marshy area of a cut-over palm plantation near Ndian village, approximately $200 \mathrm{~m}$ from the KNP boundary. One was seen in a stream in an oil-palm plantation near Mundemba on 9 November 1993. Observers: P.R., A.A.G.

African Finfoot Podica senegalensis*: RS, $r(N), u(S)$. This species seems much more regular in the south of KNP/KPA than the north. However, it may be found at Lake Ejagham in the north of KPA, where appropriate habitat exists. A.A.G. has seen the species in the south near Mundemba on the Mana, Ndian and Akwayafé Rivers, and on streams in oil-palm plantations. It can be found on rivers, streams and still waters both in forest and out. It is also found in the mangroves just south of KPA (Serle 1965). Observers: J.T., P.A., P.A.D., A.A.G.

African Jacana Actophilornis africana: RS, u(S). A.A.G. finds this species uncommon along the Mana River in the south of KNP and common on the Moko River, south of Mundemba, on the southern boundary of KPA. It has not been recorded from the north of KNP/KPA. It is found on rivers, streams and small ponds. Observers: P.A., P.R., P.A.D., A.A.G.

Senegal Thick-knee Burhinus senegalensis: LM, r/u(S). Few records exist in $\mathrm{KNP} / \mathrm{KPA}$ and all but one have come from the south. P.R. recorded it in the north of the KPA just south of Manyemen. Its movements within the area are uncertain as records are few, but it is probable that it moves locally in response to fluctuating water levels on the larger rivers it frequents (Louette 1981a). Observers: J.T., P.A., P.R.

Rock Pratincole Glareola nuchalis*: RS, $r(N), f(S)$. Frequently seen on large rocks in the Mana River in the southern part of KNP/KPA. In the north of KNP/KPA 
it has rarely been recorded, but it may be overlooked. Dejaifve (1991) saw one juvenile of the species in mid-March on the Mana River near Mundemba. Observers: many.

Little Ringed Plover Charadrius dubius: PM, r(S). P.A. observed this species on a few occasions on the Mana River in the south of KNP, the only records for the park. It is abundant on mudflats in the Rio del Rey, just south of Korup. Observer: P.A.

Forbes's Plover Charadrius forbesi: LM/AM, r(N), r(S). There are few records for Korup. Dejaifve (1991) noted it during the dry season at Baro, the only observation for the north of KNP. Observers: P.A., P.A.D.

White-fronted Plover Charadrius marginatus: RS/LM, r(S). Only known from the south of KNP. It was also recorded by Thomas (in press) in the Rio del Rey just south of KNP/KPA. Observer: P.A.

White-headed Lapwing Vanellus albiceps: RS/LM, u/f(S). This species undergoes local movements in response to fluctuating water levels on large rivers (Louette 1981a). So far it is known only from the south of KNP/KPA where there is more suitable habitat, but should be found on large rivers in the north. A.A.G. has found it frequent on the Moko River, outside KNP and just south of Mundemba, and also on the Ndian River. Observers: P.A., P.A.D., A.A.G., P.R.

Marsh Sandpiper Tringa stagnatilis: $\mathrm{PM}, \mathrm{r}(\mathrm{S})$. The sole record of this species for KNP/KPA comes from the area south of Mundemba on 6 September 1992. Additional records from larger rivers and wetlands are expected. In the Rio del Rey, just south of KNP, it is certainly more frequent (Thomas in press). Observer: A.A.G.

Common Greenshank Tringa nebularia: PM, $\mathrm{u}(\mathrm{S})$. There are few records in $\mathrm{KNP} / \mathrm{KPA}$, although Thomas (in press) reported it in numbers in the nearby Rio del Rey between December 1978 and February 1979. In 1992 it was seen near Mundemba by A.A.G. on 23 February and 19 August, and by P.R. on 3 October. Observers: P.A., A.A.G., P.R.

Wood Sandpiper Tringa glareola: $\mathrm{PM}, \mathrm{r}(\mathrm{N}), \mathrm{u}(\mathrm{S})$. There are few records for the north of KNP/KPA. A.A.G. found it on the Korup River in Erat, and five birds in a wet field near Mundemba on 19 August 1992, with further records near Mundemba on 28 October and 9 December 1992 and 17 and 24 November 1993. Observers: P.A.D., A.A.G., P.R.

Common Sandpiper Actitis hypoleucos: PM, c(N), c(S). The commonest wintering shorebird in KNP/KPA. It is found along forested rivers, and almost anywhere near water (except on small forest streams) from July to May. Although most individuals arrive in August, P.R. observed a possible early migrant on 1 July 1992 near Nguti and A.A.G. had one on 17 July 1993 at Mundemba. However, 
Brosset and Erard (1986) have recorded summering immatures in Gabon, so it is possible that these birds were lingerers. Observers: many.

African Green-pigeon Treron calva*: RS, $f / c / a(N), f / c / a(S)$. A species of primary and secondary habitats whose presence is often correlated with fruiting trees. At times when fruits such as Musanga are plentiful, it can be abundant in farms and secondary forest. It seems less common in primary forest. P.A.D. observed nest-building in late January into February 1991, and P.R. observed building in May 1991. Observers: many.

Blue-headed Wood-dove Turtur brehmeri*: RS, $c(N), c(S)$. This species is found in primary and older secondary forest in the north and south of KNP/KPA. Although its song is commonly heard year round, it is not easily seen in the forest. Observers: many.

Tambourine Dove Turtur tympanistria*: RS, u(N), u(S). An infrequently observed species of KNP/KPA which may have been partially overlooked owing to its discreet nature. It is found in farms and secondary forests, but was not recorded in primary forest. P.A.D. noted a recently fledged juvenile in early April 1991 near Kumba. Observers: P.A., P.A.D., A.A.G., P.R.

Red-billed Wood-dove Turtur afer: RS, c(N), a(S). This is a common species throughout KNP/KPA in villages and farms, but is absent from primary forest. Observers: many.

Western Bronze-naped Pigeon Columba iriditorques*: RS, r(S); RDB candidate. There are few reports of this species in KNP/KPA. P.A. noted it on several occasions in the forest canopy in the south of KNP, where an individual was captured by a Project Raleigh team (Anon. 1989). These records represent the first in Cameroon north of the Sanaga River (Louette 1981a). Observers: P.A., Project Raleigh.

Grey Wood-pigeon Columba unicincta*: RS, $\mathrm{u} / \mathrm{f}(\mathrm{N}), \mathrm{f}(\mathrm{S})$. Commoner in the south of KNP/KPA than in the north, where it was recorded infrequently. The reasons for this apparent difference are uncertain, but the presence of oil-palm plantations may be important, as Grey Parrots are seen daily in them, where they are believed to feed on the nuts. The pigeon is found in primary and secondary forest, and on farms at forest edge. Observers: many.

Lemon Dove Columba larvatat: RS, $\mathrm{r}(\mathrm{S})$. This montane species was recorded by P.A. in the south of KNP at Mt Yuhan, near Ekundu Kundu. P.R. found it uncommon in RHFR where records were between 1,200 and $1,450 \mathrm{~m}$ in primary and secondary forest. However, the species's abundance may have been underestimated given that it tends to call only infrequently (Eisentraut 1956). Observer: P.A.

Red-eyed Dove Streptopelia semitorquata: RS/LM, f/c(S). A species known only from the south of KNP/KPA, though it should occur in the north. It was 
recorded in oil-palm plantations, towns and open secondary habitats. It is said to be especially abundant in the coastal mangroves of the Southwest Province (Serle 1965). In the south of Korup A.A.G. found it absent in July-September 1991 but present during this period in 1992 and 1993, perhaps indicating local movement in the area. Urban et al. (1986) also mention that the species moves locally in Cameroon. P.A.D. observed a bird carrying nest material in midMarch. Observers: P.A., P.A.D., A.A.G., P.R.

Grey Parrot Psittacus erithacus ${ }^{*}$ RS, c/a(N), a/v(S). Flocks of this species are commonly seen in the morning and evening, especially in oil-palm plantations near Mundemba where large numbers occur (e.g. P.R. and P.A.D. observed over 500 birds there in mid-March 1991). However, large concentrations have been recorded in the north, especially in farms when Dacryodes ("plum tree") is fruiting. The species is found in both primary and secondary habitats, but is uncommon in the Rumpi Hills above 1,00o m. In the Korup area there was little evidence of an active trade in the species, though occasional reports of parrot collectors travelling from village to village were noted. Observers: many.

Red-fronted Parrot Poicephalus gulielmi*: RS, u(N), u(S). Although Louette (1981a) stated that this species is possibly absent from western Cameroon, Serle (1954) reported its occurrence at Kumba and Mbonge (near Ekondo Titi). In the KNP it has been recorded in primary and logged forests. Observers: P.A., P.S. and co-workers, P.A.D., P.R.

Great Blue Turaco Corythaeola cristata*: RS, $c(N), c(S)$. A common species of the lowland primary and secondary forests and farms in KNP/KPA. Although Serle (1950) reported observing the species at altitudes of up to 2,130 m in western Cameroon, P.R. recorded it very infrequently in RHFR, and never above 1,200 m. Observers: many.

Green Turaco Tauraco persa* ${ }^{*}$ RS, $r / d(N), r / d(S)$. The abundance of this species in KNP/KPA is uncertain. Although few individuals have been observed there, it is possible that it is overlooked given that its vocalizations are similar to those of the commoner T. macrorhynchus. Observers: P.A.D., A.A.G., P.R.

Yellow-billed Turaco Tauraco macrorhynchus*: RS, c/a(N), a(S). In KNP/KPA this is a widespread and common bird of both primary and secondary forest. It is also known from RHFR and NAFR. Observers: many.

African Striped Cuckoo Oxylophus levaillantii*: AM, $r(N)$. There are three dry season records of this intra-African migrant in the Korup area. P.A.D. noted it at Baro in January and February 1991 and P.R. found it in farms at Nguti in December 1991. Observers: P.A.D., P.R.

Red-chested Cuckoo Cuculus solitarius*: RS, c(N), c(S). This cuckoo is common in the middle strata and canopy of lowland primary and secondary forests in $\mathrm{KNP} / \mathrm{KPA}$. In RHFR and NAFR it was less frequently recorded. It was not heard during the dry season. Observers: P.A., P.A.D., A.A.G., P.R. 
Black Cuckoo Cuculus clamosus*: RS, $c(N), c(S)$. Common in the middle strata and canopy of primary and secondary forests of KNP/KPA. Less frequently heard than $C$. solitarius, but heard throughout the year. The subspecies $C$. $c$. gabonensis is resident in the Korup area, but it is possible that the migratory subspecies C. c. clamosus from southern Africa could occur given that it has been recorded in the montane district of western Cameroon (Bannerman 1930). Observers: S.N.S. and co-workers, P.A.D., P.R.

Dusky Long-tailed Cuckoo Cercococcyx mechowi*: RS, r(N), r(S). There are very few records in KNP/KPA. P.R. heard two birds counter-singing in logged forest near Baro on 7 April 1992, and a third was heard near Nguti in mid-April of the same month. Although Louette (1981a) states that $C$. mechowi is common in the forests of the southern half of Cameroon, it is certainly not common in the Korup area. Observers: P.A., P.R.

Olive Long-tailed Cuckoo Cercococcyx olivinus*: RS, $\mathrm{f}(\mathrm{N}), \mathrm{u}(\mathrm{S})$. This species is fairly common in the middle strata and canopy of primary and logged forests of KNP/KPA. P.R. recorded it in the Rumpi Hills, as did Stuart (1986). Observers: J.T., P.R.

African Emerald Cuckoo Chrysococcyx cupreus*: RS, c(N), c(S). A common species of primary and secondary forests, farms and villages in KNP/KPA. P.R. noted it up to 1,600 $\mathrm{m}$ in RHFR and NAFR. Heard singing throughout the year. Observers: many.

Yellow-throated Cuckoo Chrysococcyx flavigularis ${ }^{*}$ : RS, $r(S)$. Recorded once in the south of the KNP. Records from elsewhere in the Southwest Province are very few. Observers: P.S. and co-workers.

Klaas's Cuckoo Chrysococcyx klaas*: RS, $\mathrm{f}(\mathrm{N}), \mathrm{f}(\mathrm{S})$. This cuckoo frequents the canopy of primary and secondary forests, and tall trees in farms of KNP/KPA. P.R. recorded it in RHFR and NAFR, and noted it singing year-round. Observers: J.T., P.A., S.N.S. and co-workers, P.A.D., P.R.

Dideric Cuckoo Chrysococcyx caprius: $\mathrm{RS}, \mathrm{u}(\mathrm{N}), \mathrm{u} / \mathrm{f}(\mathrm{S})$. This species is found in farms and villages in KNP/KPA, and its song is heard at all seasons. Observers: P.A., T.G., P.A.D., P.R.

Yellowbill Ceuthmochares aereus*: RS, $c(\mathrm{~N}), \mathrm{c}(\mathrm{S})$. This species is present in mixedspecies foraging flocks in the middle strata of primary and secondary forests and farms. It is widespread in KNP/KPA, but was not recorded above $1,300 \mathrm{~m}$ in RHFR and NAFR. Its call was heard throughout the year. Observers: many.

Black-throated Coucal Centropus leucogaster*: RS, $f(N), f(S)$. A species of the understorey and middle strata of primary and secondary forests, recorded by P.R. up to $1,500 \mathrm{~m}$ in RHFR. Observers: many. 
Senegal Coucal Centropus senegalensis: RS, d(S). A species of secondary growth and farms in KNP/KPA. It is known from the south of KNP/KPA in large plantations near Mundemba, but should occur in the north. Although difficult to distinguish from $C$. monachus, it seems much less common. Stuart (1986) reported it at Dikome Balue in the Rumpi Hills. Its status in Korup is uncertain. Observers: P.A., P.A.D., A.A.G., P.R.

Blue-headed Coucal Centropus monachus*: RS, $\mathrm{f} / \mathrm{c}(\mathrm{N}), \mathrm{f} / \mathrm{c}(\mathrm{S})$. Although there are difficulties in distinguishing between this species and $C$. senegalensis, it is apparent that $C$. monachus is the common Centropus of village farms and forest clearings in KNP/KPA. Observers: P.A., P.R., A.A.G.

Barn Owl Tyto alba: RS, $\mathrm{r}(\mathrm{S})$. Probably rare in KNP/KPA. Although two Tyto owls seen by P.R. at Dikome Balue $(1,200 \mathrm{~m})$ in the Rumpi Hills were most likely $T$. alba, the possibility that they were African Grass Owls $T$. capensis should not be ruled out. T. capensis is known primarily from southern Africa, but has an isolated population occurring in montane areas of western Cameroon. There are three records from Mt Manenguba, approximately $50 \mathrm{~km}$ east of the Rumpi Hills (Fry et al. 1988). Observer: P.A.

White-faced Scops-owl Otus leucotis: RS, r(S). A.A.G. reported three adults roosting in a tall tree near Mundemba from December 1991 to February 1992. At Nguti several flightless juvenile birds were raised by a local resident. The only other record of this species in the Southwest Province comes from Serle (1950), who recorded it on Mt Manenguba. Observers: A.A.G., P.R.

Maned Owl Jubula lettii*: RS, r(S); RDB candidate. This species has been recorded rarely in KNP/KPA. Its habitat in south-western Congo is permanently and seasonally flooded forest (Dowsett-Lemaire 1992), so it is possible that it is commoner in the south of KNP/KPA, where this habitat is more prevalent. Observers: P.A., S. Bearder, P. Honess.

Fraser's Eagle-owl Bubo poensis*: RS, $\mathrm{u}(\mathrm{N}), \mathrm{u}(\mathrm{S})$. This species is uncommon, but has been regularly recorded in KNP/KPA. Observers: P.A.D., S. Bearder, P. Honess, P.R.

Akun Eagle-owl Bubo leucostictus*: RS, r(S); RDB candidate. Little is known of this species in Korup. Observer: P.A.

Vermiculated Fishing-owl Scotopelia bouvieri*: RS, r(N), u(S); RDB candidate. Recorded more frequently in the south of KNP than the north, but may be commoner in the north. Observers: S.N.S. and co-workers, P.A.D., S. Bearder, P. Honess, P.R.

Chestnut-backed Owlet Glaucidium sjostedti*: RS, $f(N), f(S)$; RDB candidate. A primary forest species which is known from the north and south of KNP and RHFR. Observers: many. 
African Wood-owl Strix woodfordi*: RS, c(N), c(S). This owl is known from locations throughout KNP/KPA, including the highest peak of the Rumpi Hills $(1,768 \mathrm{~m})$. It is found in primary and secondary forest, and forest edge. Observers: many.

Bates's Nightjar Caprimulgus batesi*: RS, r(N), r(S); RDB candidate. A forest species which in Cameroon is known from only two specimens (Louette 1981a). P.A.D. observed it on three occasions in KNP and felt it was rare but widespread. Records from Korup represent the westernmost for the species and are apparently the first anywhere outside the South and East Provinces of Cameroon (Fry et al. 1988). Observers: P.A., P.S. and co-workers, P.A.D.

Brown Nightjar Caprimulgus binotatus*: RS, r(S); RDB candidate. There is currently only one record of this forest species for KNP and this comes from the vicinity of Mundemba. It is rare and local, being known from only a few locations in Cameroon (Louette 1981a). In addition, this record seems to represent the first in Cameroon outside the South Province (Fry et al. 1988). Observers: P.S. and co-workers.

Long-tailed Nightjar Caprimulgus climacurus: $A M, d(N), f(S)$. Records have come only during the dry season. Hence it is likely that it is the migratory subspecies C. c. climacurus, which breeds in the Sahel during the wet season (Fry et al. 1988), that is found in the Korup area. In fact, Serle (1965) reported collecting this race at Kumba, where he considered it fairly common in forest clearings. Observers: P.S. and co-workers, P.A.D., A.A.G.

Standard-winged Nightjar Macrodipteryx longipennis: AM, r(S). The species has been recorded only once, in the south of KNP/KPA in March 1991, but it may occur regularly, since it is present in the forests of Cameroon during the dry season, migrating north to breed (Louette 1981a). Observer: P.A.D.

Pennant-winged Nightjar Macrodipteryx vexillaria: $\mathrm{AM}, \mathrm{r}(\mathrm{S})$. The only record in KNP/KPA comes from Mundemba where A.A.G. observed an individual on 18 August 1992. This was probably a migrant from the north on its way to breeding areas in southern Africa. Observer: A.A.G.

Sabine's Spinetail Rhaphidura sabini*: RS, c(N), c(S). The commonest spinetail in the Korup area. Records come from throughout KNP/KPA, including NAFR and RHFR. P.R. observed it in groups of up to 40 over forest and secondary habitats. Observers: many.

Black Spinetail Telacanthura melanopygia*: RS, r(N); RDB candidate. Fry et al. (1988) mention only three records for Cameroon (Sangmélima, South Province). Hence recent records from Mt Kupe (C. Bowden verbally 1992), Limbe (C. Bowden, E. Bowden and P.R. in June 1992) and KNP/KPA represent the first for the Southwest Province and suggest that the species is not as rare as previously believed. Within KNP/KPA it is known from Baro (two sightings of 1-3 birds in the wet season of 1992), Nguti (4 or 5 birds in July 1992), and 
Osirayib (east of Baro), where two birds were observed in June 1992 (C. Bowden and P.R.). It has been recorded over farms and forest and in both single-species and mixed-species flocks. Observers: P.R., C. Bowden, E. Bowden.

Mottled Spinetail Telacanthura ussheri*: RS, $u(N)$. Few records exist in KNP/KPA, but it is possible that it has been overlooked. Dejaifve (1991) believed it was uncommon above forest clearings, fields and villages. Interestingly, Serle (1950) considered it the most widespread of the spinetails in the Kumba subdivision. Observers: P.A.D., P.R.

Cassin's Spinetail Neafrapus cassini*: RS, $\mathbf{u} / \mathrm{f}(\mathrm{N}), \mathrm{u} / \mathrm{f}(\mathrm{S})$. This species is widespread in KNP/KPA, but seems fairly uncommon where it occurs, being greatly outnumbered by Rhaphidura sabini in spinetail foraging flocks. Recorded above primary and secondary forest and farm-bush. A.A.G. reported a flock of 24 birds near Mundemba. Observers: P.A., T.G., P.A.D., A.A.G., P.R.

African Palm Swift Cypsiurus parvus: RS, u(N), a(S). A widespread species in $\mathrm{KNP} / \mathrm{KPA}$ which frequents villages, farms and plantations. Observers: many.

African Black Swift Apus barbatus: RS, $\mathrm{u} / \mathrm{d}(\mathrm{N}), \mathrm{u} / \mathrm{d}(\mathrm{S})$. The abundance of this swift in KNP/KPA is uncertain given the difficulties in positively identifying certain Apus swifts, but it has been recorded in both the north and south of KNP. A flock of 50 was observed by A.A.G. at the Mana River bridge near Mundemba on 22 June 1991. Observers: A.A.G., P.R.

European Swift Apus apus: PM, a(N), a(S). Present from November to May in the Korup area. It can be seen flying in large flocks over any habitat type, including primary forest. Observers: P.A., T.G., P.A.D., A.A.G., P.R.

Bates's Swift Apus batesi*: RS, r(N), r(S); RDB candidate. There are few reports from KNP/KPA. P.S. recorded two birds in the south of KNP, A.A.G. observed an individual on 18 June 1992 near Mundemba, and P.R. found the species once at Baro and once in Nguti. Elsewhere in the KPA Stuart (1986) had small numbers at Dikome Balue in the Rumpi Hills. This swift has probably been overlooked owing to problems in identifying Apus swifts. Observers: P.S. and coworkers, A.A.G., P.R.

Little Swift Apus affinis: RS, u(N), c(S). Found in open habitats of KNP/KPA, but not observed in smaller villages within the forest. Although common in towns of the Southwest Province like Mundemba, it is fairly uncommon and local in the Korup area overall. Observers: P.A.D., A.A.G., P.R.

Alpine Swift Tachymarptis melba: PM, r(S). A.A.G. observed 10 individuals with European Swifts Apus apus on Mt Yuhan in the south of KNP on 10 January 1992, providing only the second record of this Palearctic migrant for Cameroon; the first was by Stuart (1986) at Mt Cameroon, apparently overlooked by Fry et al. (1988). Observers: A.A.G. 
Bare-cheeked Trogon Apaloderma aequatoriale*: RS, f/c(N), u/f(S); RDB candidate. This species is fairly common in KNP/KPA, though it is usually heard and not seen. P.R. and P.A.D. captured it only once at IRS. It was recorded in primary forest, but also in logged forests where the canopy was relatively intact. Observers: J.T., P.A.D., P.R.

Chocolate-backed Kingfisher Halcyon badia*: RS, u(N), u(S). A species which frequents the middle forest strata and canopy, though it is sometimes captured in mist-nets placed in the understorey. It seems less common than $H$. malimbica. Observers: J.T., P.A., S.N.S. and co-workers, P.A.D., P.R.

Grey-headed Kingfisher Halcyon leucocephala: $A M, r(N), u(S)$. Few records of this intra-African migrant exist for KNP. P.A.D. observed it at Ikenge village in the north of KNP in mid-January 1991, and A.A.G. noted several birds in Mundemba in December 1992 and January 1993, and saw others there on 18 and 24 November 1993. Serle (1965) recorded it from November to April in forest clearings of western Cameroon and once observed "a rush of migrants" in early December at Kumba. Observers: P.A.D., A.A.G.

Blue-breasted Kingfisher Halcyon malimbica*: RS, $f(N), f(S)$. A species of primary and secondary forests, rivers and mangroves. In forest it is often heard in the canopy, but it also attends driver ant columns and is occasionally captured in understorey mist-nets. It was recorded widely in KNP/KPA, but seemed absent above $1,100 \mathrm{~m}$ in RHFR. On 16 August 1991 a 2-3 week old juvenile was seen with an adult at IRS. Observers: many.

Woodland Kingfisher Halcyon senegalensis: RS, $f(N), c(S)$. This species is found in farms and villages. It was recorded throughout KNP/KPA, including small villages like Ikenge and Baro, but it was not observed by P.R. in RHFR above 1,000 m. Observers: many.

African Dwarf Kingfisher Ceyx lecontei*: RS, $f(N), f(S)$. This species was captured regularly in understorey mist-nets at IRS, though less commonly than Corythornis leucogaster. It was observed in the understorey of primary and logged forests within KNP/KPA and once at a height of $15 \mathrm{~m}$ at the edge of a treefall gap. Two birds were captured with brood-patches in March and April 1991 at IRS. Observers: P.A., T.G., P.R.

African Pygmy Kingfisher Ceyx picta*: RS, u(N), c/a(S). A bird of farms, villages and towns in the Korup area. It is found in forest, but is less common in this habitat. At present, it seems commoner in forests of southern KNP than in the north. A.A.G. has found it abundant in palm plantations near Mundemba. P.R. observed a bird excavating a nest tunnel in a riverbank at Nguti in midSeptember 1992. Observers: many.

White-bellied Kingfisher Corythornis leucogaster*: RS, c(N), c(S). Among the commonest understorey birds of primary and logged forests in KNP/KPA. Although it is infrequently observed, it was commonly captured in mist-nets at IRS. Four 
birds with brood-patches were noted in August 1991 and 1992. This species is insectivorous and not necessarily associated with water. Observers: J.T., P.A., A.A.G., P.R.

Malachite Kingfisher Corythornis cristata: RS, $r(N), u(S)$. This kingfisher is uncommon in the Korup area. It is found on slow or still waters outside the forest. Most reports come from the south of KNP, but there are records from the north. P.R. observed the species at Nguti. Observers: Serle (1950), J.T., P.A.D., P.R.

Shining-blue Kingfisher Alcedo quadribrachys*: RS, $f(N), f(S)$. Found along rivers and forest streams in the Korup area. Dejaifve (1991) considered it commonest near the mangroves in the southern part of the Park. Observers: many.

African Giant Kingfisher Megaceryle maxima*: RS, $f(N), f(S)$. Found along rivers and even small forest streams of $\mathrm{KNP} / \mathrm{KPA}$. For several days in the dry season of 1992 P.R. observed a bird fishing at a small forest pool in a dry streambed. Louette (1981a) states that the subspecies $M . m$. gigantea is present in Cameroon from the Adamawa Plateau southward and that $M . m$. maxima is found in the northern part of Cameroon. However, Serle (1965) reported collecting both the forest and savanna forms at Kumba: of four $M$. maxima collected by him at Kumba, three were $M . m$. gigantea and one was $M$. m. maxima. Observers: many.

Pied Kingfisher Ceryle rudis: RS, $r(N), u(S)$. Most observations are from the south of KNP/KPA. However, the species was also recorded in the dry season on several occasions at Nguti where it is uncommon. Observers: many.

Blue-headed Bee-eater Merops muelleri*: RS, $\mathrm{u}(\mathrm{N}), \mathrm{u}(\mathrm{S})$. Found in small clearings of primary forest, treefall gaps and along forested streams and rivers. A female captured in late February at IRS had a well-developed brood-patch and Serle (1954) captured a female at a nest on 12 January. Observers: J.T., P.A., S.N.S. and co-workers, P.R.

Black Bee-eater Merops gularis*: RS, u(N), u(S). An uncommon bird in KNP/KPA. Gartshore (1984) found a nest on 4 March 1984 in the south of KNP. P.R. observed it in RHFR and NAFR as high as 1,250 m. Observers: many.

White-throated Bee-eater Merops albicollis: AM, c(N), a(S). A sometimes abundant species in forest clearings and farms which is found in KNP/KPA during the dry season from October through April. It has also been recorded from RHFR and NAFR. In NAFR P.R. recorded a flock of probable migrants flying northward over primary forest at $1,250 \mathrm{~m}$ on 22 April 1992. Observers: J.T., P.A., P.A.D., A.A.G., P.R.

European Bee-eater Merops apiaster: PM, $r(\mathcal{S})$. There are few records in KNP/KPA. P.A. occasionally saw flocks flying above the forest canopy in the south of KNP. In March 1984 Stuart (1986) noted small numbers at Dikome Balue near RHFR. Observer: P.A. 
European Roller Coracias garrulus: PM, r(S). There are few records of this Palearctic migrant in Cameroon (Louette 1981a); three of them are from the south of KNP from January through March. Observers: S.N.S. and co-workers, A.A.G., P.A.D., E.L., P.R.

Broad-billed Roller Eurystomus glaucurus: AM, r(s). A dry season visitor to the forests of Cameroon (Louette 1981a). At least one individual was seen in a group of seven rollers in KNP along the Ndian River on 28 November 1993. Observers: C. Bowden, B. Quantrill, R. Quantrill, A.A.G.

Blue-throated Roller Eurystomus gularis*: RS, $f(N), f(S)$. Seen singly or in small groups in primary and logged forests and forest edge. Records are from the north and south of KNP, NAFR and RHFR, where it was observed up to $1,200 \mathrm{~m}$. Serle (1965) collected two birds at Eyumojock and one at Ndoi $(25 \mathrm{~km}$ north of Kumba), all three of which were E. g. neglectus. Louette (1981a) states that there is a hybrid zone between the subspecies, so it is possible that both could occur in the Korup area. P.R. observed a bird carrying food in late September 1992. Serle $(1965,1981)$ mentions evidence of breeding in the months of March and August. Observers: many.

White-crested Hornbill Tockus albocristatus*: RS, $u / f(N), u / f(S)$. Uncommon in the understorey and middle strata of the forest. Recorded in primary forest and logged forest near Baro in the north of KNP. In Korup it associates with groups of foraging arboreal monkeys, as reported by Brosset and Erard (1986) in Gabon. Observers: many.

Black Dwarf Hornbill Tockus hartlaubi*: RS, $\mathrm{u}(\mathrm{N}), \mathrm{u} / \mathrm{f}(\mathrm{S})$. This species has been recorded more frequently in the south of KNP than in the north. It is found in primary and logged forests. Serle (1954) considered it rare at Kumba. Observers: many.

Red-billed Dwarf Hornbill Tockus camurus*: RS, $c(N), c(S)$. This bird is found in small groups often in mixed-species bird flocks. It typically occurs in the lower and middle strata of primary forest and forest edge, but has also been recorded in logged forest near Baro. It was not recorded in RHFR or NAFR above $900 \mathrm{~m}$. Observers: many.

African Pied Hornbill Tockus fasciatus*: RS, c/a(N), c/a(S). The commonest hornbill of primary and secondary forests and farms in the Korup area. It is uncommon in areas above $1,200 \mathrm{~m}$ in RHFR. Observers: many.

Piping Hornbill Ceratogymna fistulator*: RS, c(N), c(S). A common species of KNP/KPA which is seen in groups in primary and secondary forests and farms. Absent above 1,100 $\mathrm{m}$ in RHFR and NAFR. Observers: many.

Black-and-white-casqued Hornbill Ceratogymna subcylindricus*: RS, $\mathrm{r}(\mathrm{S})$. The only observations of this species in Korup are by P.S., who observed birds on two consecutive days in the south of KNP. There are to our knowledge no other 
records for this species in western Cameroon. Observers: P.S. and co-workers.

Brown-cheeked Hornbill Ceratogymna cylindricus*: RS, $c(N), f(S)$; RDB candidate. This hornbill is found in small groups in the canopy and sub-canopy of primary and logged forest. It was not recorded in areas over $1,000 \mathrm{~m}$ in NAFR or RHFR. Observers: P.A., P.S. and co-workers, P.A.D., A.A.G., P.R.

Black-casqued Wattled Hornbill Ceratogymna atrata*: RS, c(N), c(S). Commonly seen in groups in the canopy of primary and logged forest, such as those near Baro. P.R. did not observe it above $1,000 \mathrm{~m}$ in RHFR. Observers: many.

Yellow-casqued Wattled Hornbill Ceratogymna elata*: RS, f/c(N), f/c(S); RDB candidate. This species was found throughout the KPA/KNP, but was not recorded in RHFR above $1,000 \mathrm{~m}$. It was noted in primary forest and in logged forests around Baro. It appears slightly less common than C. atrata in the Korup area. Observers: many.

Bristle-nosed Barbet Gymnobucco peli*: RS, f/c/a(N), f/d(S). Louette (1981a) states that this species is found throughout the Cameroon forest district, but is absent from montane areas. This agrees with observations by P.R. in RHFR, where it was recorded only once $(1,100 \mathrm{~m})$. It seems commonest in secondary growth, especially in farms where it can be seen in large numbers at fruiting trees. In early June 1991 near Baro P.R. observed adults feeding a juvenile on fruit of Musanga. At a large colony in a dead tree near Baro on 22 July 1992 at least 100 cavities were occupied by Gymnobucco barbets. Approximately 80\% of these birds were G. peli and $20 \%$ were G. calvus. Many adults were bringing food to nestlings near fledging, while some adults were excavating nest cavities. Observers: P.A., T.G., P.A.D., A.A.G., P.R.

Naked-faced Barbet Gymnobucco calvus*: RS, $\mathrm{f} / \mathrm{c} / \mathrm{a}(\mathrm{N}), \mathrm{f} / \mathrm{c}(\mathrm{S})$. This species is found in primary forest, but seems commonest in farms and second growth where it can be abundant at fruiting trees, especially Musanga. In RHFR it was found up to $1,700 \mathrm{~m}$ and greatly outnumbered $\mathrm{G}$. peli. However, the relative abundance of these two species in lowland forest in Korup is still uncertain: despite the predominance of peli at a colony near Baro on 22 July 1992 (see preceding entry), on other occasions near Baro P.R. noted calvus as commoner than peli. P.R. observed nesting near Dikome Balue at 1,200 $\mathrm{m}$ in November 1991, and near Mundemba in September 1992. Observers: P.S. and co-workers, P.A.D., A.A.G., P.R.

Speckled Tinkerbird Pogoniulus scolopaceus*: RS, c(N), c(S). A common species in forest edge and farms of KNP/KPA which is absent from primary forest. It was uncommon above 1,000 $\mathrm{m}$ in RHFR. Observers: many.

Red-rumped Tinkerbird Pogoniulus atroflavus*: RS, c(N), c(S). A common and widespread species in primary forest, forest edge and village farms. It was not seen by P.R. above $1,400 \mathrm{~m}$ in RHFR. In Korup it is slightly less common than $P$. subsulphureus. Observers: many. 
Yellow-throated Tinkerbird Pogoniulus subsulphureus*: RS,c(N),c(S). A species of primary forest and forest edge in KNP/KPA. It was not observed above $1,100 \mathrm{~m}$ in RHFR. A juvenile was seen at Nguti in August 1992 which P.R. estimated to be less than one month from fledging. Observers: P.A., S.N.S. and co-workers, P.A.D., A.A.G., P.R.

Yellow-rumped Tinkerbird Pogoniulus bilineatus*: RS, u(N), u/d(S). Found in farms and open habitats of KNP/KPA. In most places it was far outnumbered by $P$. subsulphureus. In the south of KNP/KPA it is probably also uncommon, but further information is needed. Stuart (1986) recorded the species up to 1,700 $\mathrm{m}$ in the Rumpi Hills. Observers: many.

Yellow-spotted Barbet Buccanodon duchaillui*: RS, c(N), c(S). Common throughout KNP/KPA in primary and logged forest, and village farms, but not seen above $1,300 \mathrm{~m}$ in RHFR. In primary forest it usually stays in the middle strata, but was occasionally captured in mist-nets at IRS. One female there had a broodpatch in early March 1991. Observers: many.

Hairy-breasted Barbet Tricholaema hirsuta ${ }^{*}: \mathrm{RS}, \mathrm{c}(\mathrm{N}), \mathrm{c}(\mathrm{S})$. Common throughout KNP/KPA. P.R. found it fairly common in RHFR, as did Stuart (1986). It is found in the middle strata of both primary and secondary habitats. Observers: J.T., P.A., T.G., P.A.D., P.R.

Yellow-billed Barbet Trachyphonus purpuratus*: RS, $f(N), f(S)$. A species of forest edge and farms, and also primary forest in KNP/KPA. In RHFR it was recorded up to $1,250 \mathrm{~m}$. Observers: P.A.D., A.A.G., P.R.

Cassin's Honeybird Prodotiscus insignis*: RS, $\mathbf{u}(\mathrm{N}), \mathbf{u}(\mathrm{S})$. There are few records in Korup, but it is possible that it has been overlooked by observers. P.R. and C. Bowden observed the species in logged forest near Baro, and P.R. noted it at Nguti on two occasions, and near Mundemba in the south of KNP. Observers: P.A., C. Bowden, P.R.

Lyre-tailed Honeyguide Melichneutes robustus*: RS, r(N); RDB candidate. P.R. heard this bird's display flight near Baro in early September 1992, the only record for KNP. He also recorded the species in RHFR on 9 March 1992. Observer: P.R.

Spotted Honeyguide Indicator maculatus*: RS, r/u(N), r/u(S). Few records exist in KNP/KPA. P.A.D. observed it at Baro and it was twice captured in mist-nets at IRS. Thomas (1991) captured it three times in the south of KNP. It has been recorded in primary and secondary forest, and up to 1,200 $\mathrm{m}$ in RHFR. Observers: J.T., P.A., P.A.D., P.R.

Least Honeyguide Indicator exilis*: RS, r(N). Very few records exist in KNP/KPA, though the species is probably not rare. P.A.D. recorded it near Ikenge in the north of KNP. Observers: P.A., P.A.D. 
African Piculet Sasia africana*: RS, $\mathrm{u} / \mathrm{f}(\mathrm{N}), \mathrm{u} / \mathrm{f}(\mathrm{S})$. Found in the lower strata of primary and secondary forests in KNP/KPA. It was mist-netted twice at IRS and a female with a brood-patch was noted in early March 1991. Observers: P.A., P.S. and co-workers, P.A.D., P.R.

Buff-spotted Woodpecker Campethera nivosa*: RS, $f(N), f(S)$. A common bird of the middle and lower strata of primary lowland forest in the Korup area. It was found in all localities surveyed, but only once in $\operatorname{RHFR}(1,000 \mathrm{~m})$. A male and female caught together at IRS in April 1991 both had brood-patches. A third female with a brood-patch was netted later in the same month. Observers: many.

Brown-eared Woodpecker Campethera caroli*: RS, $r(N)$. A rare species in $\mathrm{KNP} / \mathrm{KPA}$, known from primary forest and forest edge. P.A.D. observed it at IRS and at Ikenge. P.R. observed 1 or 2 individuals in RHFR in March 1992. Elgood (1982) mentions only two records for Nigeria. Observers: P.A., P.A.D., P.R.

Gabon Woodpecker Dendropicos gabonensis*: RS, $\mathrm{u}(\mathrm{N}), \mathrm{u}(\mathrm{S})$. Rather uncommon in secondary forest and farms. A.A.G. found it in primary forest where it is probably less common. P.R. recorded it at Nguti and at Baro, where it was observed excavating a nest cavity in late May 1992. Observers: P.A., T.G., P.A.D., A.A.G., P.R.

Yellow-crested Woodpecker Dendropicos xantholophus*: RS, $\mathrm{f}(\mathrm{N}), \mathrm{f}(\mathrm{S})$. A species of primary and logged forests and farms in KNP/KPA. It has been recorded in RHFR up to $1,300 \mathrm{~m}$. P.R. observed a pair copulating in November in RHFR at 1,200 m. Observers: J.T., P.A., P.A.D., A.A.G., P.R.

Rufous-sided Broadbill Smithornis rufolateralis*: RS, $\mathrm{f}(\mathrm{N}), \mathrm{c}(\mathrm{S})$. Fairly common in the lower strata of primary and logged forests. Serle (1950) collected a female with a brood-patch in late October, and a female with a brood-patch was netted at IRS in early March 1991. Observers: J.T., P.A., P.S. and co-workers P.R., A.A.G.

African Pitta Pitta angolensis*: RS, r(N), r(S). There are only three records from KNP. The earliest was at Ndian village on the boundary of the KNP by MacDonald (in Serle 1950). Doyle McKey (verbally 1991) found a window-killed bird in Mundemba, and P.A.D. recorded the species once in farms at Ikenge. Dejaifve (1991) felt it might not be rare in KNP after receiving reports of the species from local inhabitants. The nominate subspecies was reported by Serle (1950, 1959) at Ndian on the south edge of KNP. Observers: W. Serle, D. McKey, P.A.D.

Square-tailed Saw-wing Psalidoprocne nitens*: RS, c/a(N), c/a(S). In the north of $\mathrm{KNP} / \mathrm{KPA}$ this swallow can be seen in groups of 30 or more, especially at dusk, flying above primary forest, forest clearings and near villages. It is known from RHFR and NAFR. Observers: many. 
Black Saw-wing Psalidoprocne prisoptera: RS/LM?, $\mathrm{r}(\mathrm{S})$. Common in villages of RHFR. In lowland areas of KNP/KPA it is rare and so far known only from Mundemba, where A.A.G. noted it in April 1991 and 1992 (perhaps these birds are post-breeding dispersers from the Rumpi Hills). The resident race in the Korup area is $P$. $p$. petiti, but interestingly there is one specimen of $P$. $p$. chalybea collected nearby at Limbe (Louette 1981a). Observers: P.A., A.A.G.

Fanti Saw-wing Psalidoprocne obscura: LM, r(S). There are very few records, and only from the south of KNP. Serle (1950) collected it at Kumba once. Observer: P.A.

Banded Martin Riparia cincta: AM, r(S). The one record in KNP was on 17 March 1991 near Mundemba. The subspecies of this bird was not noted, but both $R$. c. cincta and $R$. c. paroula are possible. According to Louette (1981a), nominate cincta is said to occur as a migrant in Cameroon from May to August, while paroula is resident. However, Keith et al. (1992) indicate that both are present in Cameroon as migrants during the non-breeding season. Observers: P.A.D., P.R.

Grey-rumped Swallow Pseudhirundo griseopyga: AM?, r(S). There are very few records in KNP/KPA and its status is uncertain. A.A.G. observed it at Mundemba on 27 July 1992, saw 26 in an oil-palm plantation there on 29 July 1993, and had four around his house in Mundemba during July and August 1993. Apparently the only other record for the Southwest Province was at Mt Manenguba (Stuart 1986). Observers: P.A., A.A.G.

Red-breasted Swallow Hirundo semirufa: $R S / A M /$ ?, $f(N), f / c / a(S)$. The migratory status of this species in KNP/KPA is not well understood. In Mundemba, A.A.G. has found it abundant from March to July, then far less common or absent, August to October, and irregular from November to February; however, in 1993 rainfall was much lower than normal, and these swallows remained in the Mundemba area until mid-September. Serle $(1965,1981)$ recorded nesting in western Cameroon from late January through to July. P.R. found a pair building on 22 May 1992 at Nguti and P.A.D. observed nest building near Mundemba in March 1991. Observers: P.S. and co-workers, P.A.D., A.A.G., P.R.

Mosque Swallow Hirundo senegalensis: LM/AM, $f(S)$. A swallow of open habitats, fields and plantations, thus far only observed in the south of KNP/KPA and present in Korup from at least March to May. Observer: P.S. and co-workers P.A.D., A.A.G., P.R.

Lesser Striped Swallow Hirundo abyssinica: RS/LM, f(S). A species of villages and open areas which has not been recorded in the north of KNP. It is more widely distributed in the KPA. Its migratory status in KNP/KPA is uncertain. A.A.G. observed it at Mundemba from January to June, and in October and November. P.R. recorded it year-round at Nguti where in September 1992 some birds were nest building, while some juveniles were seen flying with adults. Serle (1950) 
noted nesting at Kumba from February to May. Observers: P.A.D., A.A.G., P.R.

Forest Swallow Hirundo fuliginosa*: RS, r(S); RDB candidate. Recorded only rarely in lowland forest of KNP/KPA, but more regular in the Rumpi Hills where P.R. and Stuart (1986) noted it. Observers: P.A., P.R.

Wire-tailed Swallow Hirundo smithii: RS?, f(S). A.A.G. recorded this species occasionally at Mundemba from May through November 1991-1993 as well as during January and February 1993. A pair built a nest in his shed at Mundemba in July, fledging two young on 5 September 1993. P.R. also recorded this swallow at Nguti, and A.A.G. found it at Osirayib in June and July 1993. Observers: A.A.G., P.R.

White-throated Blue Swallow Hirundo nigrita*: RS, $c(N), c(S)$. A riverine species which seems commoner in the south of KNP/KPA than in the north. A dry season breeder according to Serle (1981). Young birds were observed by P.A.D. in March and early April. Observers: many.

Barn Swallow Hirundo rustica: PM, c/a(N), a/v(S). Common to very abundant in open habitats from late September through April, with occasional birds lingering to May. It is commonest in larger towns, but also found in small villages within forest. Observers: many.

Yellow Wagtail Motacilla flava: PM, $\mathrm{f}(\mathrm{N}), \mathrm{c} / \mathrm{a}(\mathrm{S})$. A dry season migrant to the Korup area, in open habitats such as villages and along roads. The first individuals are seen in October and the last in April. Observers: P.A., P.S. and co-workers, P.A.D., A.A.G., P.R.

Mountain Wagtail Motacilla clara: $R S, f / c(N), f / c(S)$. Widespread in lowland forest along rivers and streams in KNP/KPA. P.R. also noted it on streams at 1,200 m in RHFR. In March 1991 at IRS three juveniles were captured with unossified skulls. Observers: J.T., P.A., S.N.S. and co-workers, P.A.D., P.R.

African Pied Wagtail Motacilla aguimp: LM, $\mathrm{f}(\mathrm{S})$. This species has been observed in Korup from November to August, but there are no records for September and October. It is probable that it leaves the area periodically as Keith et al. (1992) mention that it wanders locally. It is found in open habitats near villages. All KNP records come from the Mundemba area. Serle (1965) had the species at Bakebe in the north of the KPA. Observers: P.A., P.S. and co-workers, P.A.D., A.A.G., P.R.

Richard's Pipit Anthus novaeseelandiae: RS/LM?, u/f(S). This pipit frequents grassy areas and roadsides and has been noted at Mundemba, Nguti and in RHFR. It has been recorded in Korup during almost every month of the year, but A.A.G. found it scarce from mid-December to March. The subspecies $A$. $n$. cameroonensis is expected within KNP/KPA. Observers: P.S. and co-workers, A.A.G., P.R. 
Blue Cuckoo-shrike Coracina azurea*: RS, c(N), c(S). Common in the middle strata and canopy of primary and logged forests. Records come from many localities in KNP/KPA, but it was not recorded at either RHFR or NAFR above $900 \mathrm{~m}$. Observers: many.

Little Greenbul Andropadus virens*: RS, c/a(N), c/a(S). A very common species of thick undergrowth in primary and secondary forest and farms. It is found in all parts of KNP/KPA, but was not recorded above 1,600 m in RHFR. Females with brood-patches were recorded by P.A.D. and P.R. in July and August at IRS, and Serle (1965) mentions breeding at lowland forest localities in March, May and June. It does not usually attend mixed-species bird flocks in the forest, except at fruiting trees. Observers: J.T., P.A., P.A.D., A.A.G., P.R.

Little Grey Greenbul Andropadus gracilis*: RS, d(N), d(S). The abundance of this species in Korup is uncertain at present. It seems commoner in farms and edge habitats, often at fruiting trees. Stuart (1986) recorded small numbers in primary forest in the south of KNP and in the Rumpi Hills up to 1,200 m, where P.R. also recorded it. Serle $(1950,1954,1964)$ reported collecting far fewer $A$. gracilis overall than $A$. curvirostris or $A$. ansorgei in the Southwest Province. Observers: P.A., S.N.S. and co-workers, P.S. and co-workers, P.A.D., P.R.

Ansorge's Greenbul Andropadus ansorgei*: RS, c(N), c(S). Found in primary forest, forest clearings and farms, but very difficult to distinguish from other Andropadus greenbuls. Its status was determined by the frequency with which its distinctive Brown-headed Cowbird-like call (Molothrus ater) was heard (Zimmerman 1972). It is common and widespread in KNP/KPA. Serle (1950, 1965, 1981) collected $21 A$. ansorgei in the Southwest Province, mostly from Kumba. Observers: P.A., P.R.

Plain Greenbul Andropadus curvirostris*: RS, c(N), c(S). P.R. observed and taperecorded this species in the north and south of KNP/KPA, where it is believed to be fairly common. Thomas (1991) mist-netted it in the south of KNP, and Serle (1965) considered it abundant in the Southwest Province. He collected at least 71 individuals in the area, primarily at Limbe and Kumba. In KNP/KPA it has been documented in primary and logged forests and forest edge. Observers: J.T., P.A., P.R.

Slender-billed Greenbul Andropadus gracilirostris*: $R S, f(N), f(S)$. Fairly common in primary and logged forests and farms throughout KNP/KPA. In forest it is seen in the middle and upper strata, but much lower in clearings. It has been found up to $1,250 \mathrm{~m}$ in RHFR. At Nguti in early September 1992 P.R. saw a family group with 2-3 juveniles estimated to have fledged in mid-August. Observers: P.A., T.G., P.A.D., P.R.

Yellow-whiskered Greenbul Andropadus latirostris*: RS, c(N), c(S). Common throughout KNP/KPA in the middle and lower strata of primary and secondary forest, and farms. In RHFR it was not seen above $1,300 \mathrm{~m}$. It was rarely observed in mixed-species flocks, except at fruiting trees like Musanga. At IRS 22 records 
of females in breeding condition came during the months of March (2), May (2), July (10), August (7) and September (1). Observers: many.

Golden Greenbul Calyptocichla serina*: RS, $f(N), f(S)$. Widespread in KNP/KPA, but found in small numbers. A bird of primary and secondary forest and forest clearings, in forest it stays in the upper strata but can be seen lower in clearings. It was recorded at RHFR and NAFR up to $c$. 1,250 m. Observers: P.A., T.G., P.A.D., P.R.

Honeyguide Greenbul Baeopogon indicator*: RS, $\mathrm{f} / \mathrm{c}(\mathrm{N})$. A species of primary and logged forests and forest edge in KNP/KPA. P.R. noted it at Baro, Nfainchang (NAFR) and commonly around Nguti. Observer: P.R.

Sjöstedt's Honeyguide Greenbul Baeopogon clamans*: RS,f(N), u/f(S); RDB candidate. Widespread in KNP/KPA, occurring in small numbers. It was not found in RHFR or NAFR. It frequents the middle forest strata, but was occasionally captured in mist-nets placed near the ground at IRS. In late November 1991 at IRS a pair built a nest $10 \mathrm{~m}$ high in a $20 \mathrm{~m}$ understorey tree. The cup-like nest was covered with dead leaves on the outside, and in structure and placement was very much like that described by Erard (1977). On 10 December one bird was seen on the nest, presumably incubating eggs, but the following day the pair had abandoned it. Observers: J.T., P.A., S.N.S. and co-workers, P.A.D., P.R.

Spotted Greenbul lxonotus guttatus*: RS, c(N), c(S). A species of primary and logged forests and forest edge in KNP/KPA. Although typically a canopy species, it was observed much lower at forest edge. In RHFR and NAFR it was absent above 1,000 m. Observers: many.

Simple Greenbul Chlorocichla simplex*: RS, $f(N), f(S)$. Found in forest clearings and farms in all areas surveyed in KNP/KPA. Observers: P.A., P.A.D., A.A.G., P.R.

Swamp Palm Bulbul Thescelocichla leucopleura*: RS, $u(N), u(S)$. Found in forest, forest edge and farms, often associated with Raphia palms. It has been recorded in the north and south of KNP and in RHFR and NAFR. At Nguti P.R. observed a pair carrying nest material in mid-September 1992. Serle (1981) reported birds in reproductive condition from May through July. Observers: A.A.G., P.R.

Icterine Greenbul Phyllastrephus icterinus*: RS, a(N), a(S). Perhaps the most abundant bird in the lowland forests of KNP/KPA. In NAFR it was recorded by P.R. up to $1,266 \mathrm{~m}$, but in RHFR it was not seen above $950 \mathrm{~m}$. P. icterinus is difficult to separate from the sympatric Xavier's Greenbul P. xavieri, but biometrics taken at IRS show that around $70 \%$ of icterinus/xavieri greenbuls in Korup are icterinus. Females with brood-patches were captured in June (1), July (5), and August (3) at IRS. Serle (1950, 1965, 1981) provided breeding records during June, September, November and December. Observers: J.T., P.A., S.N.S. and co-workers, P.A.D., P.R. 
Xavier's Greenbul Phyllastrephus xavieri*: RS, u(N), u(S). An apparently uncommon species in the primary and secondary forests of KNP/KPA. Fortunately, through mist-netting it is possible to identify male $P$. xavieri and female $P$. icterinus using wing-chord measurements given in Serle (1950, 1965) (male xavieri $>82 \mathrm{~mm}$ and female icterinus $<70 \mathrm{~mm}$ ). Approximately $30 \%$ of icterinus/ xavieri greenbuls netted at IRS $(n=94)$ are xavieri. A female with a brood-patch was captured in August 1992 at IRS. This species is not mentioned by Elgood (1982) for Nigeria and is at the westernmost extreme of its range in Korup. Observers: J.T., P.A., S.N.S. and co-workers, P.A.D., P.R.

White-throated Greenbul Phyllastrephus albigularis*: RS, r(S). This species seems rare in KNP/KPA and Louette (1981a) considers it rare in Cameroon. P.A. made only a few sightings of small groups in the south of KNP. Six individuals were seen in the Ikpan block of the Cross River National Park, Nigeria (adjacent to the KNP) by Ash et al. (1989). Bannerman (1936) mentions it as occurring in the vicinity of Mt Cameroon. Observer: P.A.

Red-tailed Bristlebill Bleda syndactyla*: RS, c(N), c(S). A common forest understorey species of KNP/KPA which is often a member of bird parties attending driver ant swarms. It was not encountered above $900 \mathrm{~m}$ in RHFR, and was uncommon at the peak of NAFR $(1,266 \mathrm{~m})$. Females in breeding condition (7) were documented at IRS in March (1), July (4) and August (2). Observers: many.

Green-tailed Bristlebill Bleda eximia*: RS, $c(N), c(S)$. A species of primary and secondary forest understorey throughout $\mathrm{KNP} / \mathrm{KPA}$. It was recorded in both RHFR and NAFR up to about $1,100 \mathrm{~m}$. The species is often found in mixedspecies bird parties at ant swarms. At IRS females in breeding condition (12) were netted in July (6), August (5) and September (1). Serle (1965) recorded a breeding female in May. Observers: many.

Eastern Bearded Greenbul Criniger chloronatus*: RS, $f(N), f(S)$. A species of the lower strata of primary and secondary forest and forest edge. It was not recorded above 1,000 $\mathrm{m}$ in RHFR and NAFR. In the lowlands it is widespread, but thinly distributed in the north of KNP/KPA. At IRS a female in breeding condition was netted in August 1991. Observers: many.

Red-tailed Greenbul Criniger calurus*: RS, d(N), d(S). A species of primary and logged forest and forest edge. Because it is extremely difficult to distinguish from C. ndussumensis, its abundance in Korup is uncertain. C. Chappuis (in litt. 1993) identified vocalizations of this species recorded by P.R. in Korup. Observers: many.

White-bearded Greenbul Criniger ndussumensis*: RS, d(N). C. Chappuis (in litt. 1993) identified vocalizations of this species recorded by P.R. in Korup, but its status there remains uncertain given the difficulty in separation from $C$. calurus in the field. Observer: P.R. 
Common Bulbul Pynonotus barbatus: RS, c(N), a(S). A very common species of farms and villages. Records come from throughout KNP/KPA, including RHFR where it was observed at up to $1,650 \mathrm{~m}$. Observers: many.

Red-billed Shrike Prionops caniceps*: RS, $r(N)$. There are only two records of this shrike for the Korup area. P.A.D. observed it as did P.R. near Baro in the north of KNP, in logged forest and farms. As Louette (1981a) did not list the species for western Cameroon, these are the first records for the area. Interestingly, the species seems commoner in south-eastern Nigeria: Mackenzie (1979) considered it frequent at Calabar, and Ash et al. (1989) noted four individuals in Ikpan block of Cross River National Park, adjacent to Korup. Observers: P.A.D., P.R.

Sabine's Puffback Dryoscopus sabini*: RS, $r(N)$, u(S). P.A. recorded this species in the canopy in the south of KNP, finding it uncommon. It is fairly common in RHFR between 900 and $1,200 \mathrm{~m}$ in secondary forest and farms. P.R. observed it near Wone, south of Manyemen. Observers: J.T., P.A., P.A.D., P.R.

Many-coloured Bush-shrike Malaconotus multicolor*: RS, $r(N)$. Currently known from Baro and Nguti in the north of KNP/KPA, and RHFR $(1,250 \mathrm{~m})$ in the south of the KPA. Only at Nguti was it regularly recorded. It was observed in primary and logged forests and farms at forest edge. Observer: P.R.

West African Nicator Nicator chloris*: RS, $c(N), c(S)$. A species of primary and logged forests in the Korup area, not observed in RHFR above 1,000 m, but up to $1,100 \mathrm{~m}$ in NAFR. P.R. noted a band of yellow on the throats of two juveniles captured at IRS; given their large size, however, there was no chance that these birds were $N$. vireo. Observers: many.

Forest Robin Stiphromis erythrothorax*: RS, a(N), a(S). Very common in the understorey of primary and logged forests, though less common in the latter. Absent above 1,000 $\mathrm{m}$ in RHFR, but found to 1,100 $\mathrm{m}$ in NAFR. Often seen at driver ant swarms. At IRS 14 females with brood-patches were captured in May (4), July (6), and August (4). Observers: many.

Blue-shouldered Robin-chat Cossypha cyanocampter*: RS, r(N). Observed in primary forest in the north of KNP by A.A.G., and at IRS by P.A.D. Although Louette (1981a) considers this a common forest bird in Cameroon, it seems rare in Korup. Serle $(1954,1965)$ collected four individuals near Limbe and three at Kumba, commenting that the habitat is thick second growth in forest clearings. Observers: P.A.D., A.A.G.

Fire-crested Alethe Alethe diademata*: RS, c/a(N), c/a(S). A common lowland forest understorey species which is strongly associated with driver ant swarms. It can also be found in logged forest and forest clearings. It was not found above $1,200 \mathrm{~m}$ in RHFR. At IRS 10 females with brood-patches were captured in July (5) and August (5). Serle (1950, 1965) mentions breeding at lowland sites in May, August and October. Observers: many. 
Brown-chested Alethe Alethe poliocephala*: RS, c(N), c(S). A common understorey bird in Korup, often attending ant swarms, and found in primary and secondary forests. In RHFR it was captured at 1,700 m. At IRS eight females with brood-patches were mist-netted from May through September with a slight peak in July, and a juvenile was netted in July. Observers: many.

White-tailed Ant-thrush Neocossyphus poensis*: RS, $\mathrm{f} / \mathrm{c}(\mathrm{N}), \mathrm{f} / \mathrm{c}(\mathrm{S})$. A species of lowland primary and logged forests. In RHFR it was not found above 1,200 m. At IRS four breeding-condition females were netted in July (3) and August (1). A dependent juvenile with an adult female was captured in July. Observers: many.

Rufous Flycatcher-thrush Neocossyphus fraseri*: RS, c(N), c(S). This species frequents the middle strata of primary and logged forests in KNP/KPA. P.R. observed two spotted juveniles in NAFR at 1,250 $\mathrm{m}$ in late April 1992. At IRS in March 1991 a female with a brood-patch and a juvenile with an unossified skull were captured. Observers: J.T., P.A., S.N.S. and co-workers, P.A.D., P.R.

Whinchat Saxicola rubetra: PM, u(S). Recorded at Mundemba and Nguti. Korup records have not been sufficient to develop a clear picture of the species's abundance and dates of occurrence. Found in open habitats, such as farms and villages. Observers: P.A.D., A.A.G., P.R.

Northern Wheatear Oenanthe oenanthe: PM, r(S). There is one record from the south of KNP in palm plantations approximately $1 \mathrm{~km}$ from the Mana River. There are apparently few records from the forested parts of Cameroon. Observers: C. Bowden, R. Leslie, B. Quantrill.

African Thrush Turdus pelios: $R S, f(S)$. Found in the vicinity of larger villages and towns, such as Mundemba, Nguti and in the Rumpi Hills. It was absent in smaller villages in the interior of KNP. Observers: A.A.G., P.R.

Black-eared Ground-thrush Zoothera camaronensis*: RS, u(N), r(S); RDB candidate. Louette (1981a) mentions only five localities in Cameroon for this species. In KNP it is not rare, but extremely discreet. Recorded in the understorey of primary forest and once in logged forest near Baro. Nine birds were captured in the north of KNP, and breeding females were captured at IRS in July 1991 and at Baro in July 1992. Thomas (1991) reported capturing the species twice in the south of KNP. Observers: Serle, J.T., P.A., P.S. and co-workers, P.A.D., P.R.

Grey Ground-thrush Zoothera princei*: RS, u(N), r(S); RDB candidate. This bird of primary forest understorey is rare to very uncommon in KNP. It was captured five times at IRS while $Z$. camaronensis was captured nine times, so it may be slightly less common. There is one record for the south of KNP (Thomas 1991). Females with brood-patches were captured at IRS in March and April 1991. Observers: J.T., P.A.D., P.R. 
Brown Illadopsis Malacocincla fulvescens*: RS, $f(N), f(S)$. A species of thickets and vine tangles in lowland primary and secondary forest. It was also recorded in RHFR where an adult and a fledgling were seen at $1,300 \mathrm{~m}$ on 6 March 1992. The subspecies iboensis occurs in Korup. A female with a brood-patch was mistnetted at IRS in May 1991. Observers: S.N.S. and co-workers, P.A.D., P.R.

Pale-breasted Illadopsis Malacocincla rufipennis*: RS, c(N), c(S). Among the commonest understorey birds in primary and secondary forests of KNP/KPA. It was uncommon above $1,000 \mathrm{~m}$ in RHFR. Breeding-condition females (11) were recorded at IRS during March (6), May (3), July (1) and August (1). Observers: J.T., P.A., T.G., P.A.D., P.R.

Black-capped Illadopsis Malacocincla cleaveri*: $\mathrm{RS}, \mathrm{f}(\mathrm{N}), \mathrm{f}(\mathrm{S})$. A species of lowland forest understorey, but also observed up to 1,300 $\mathrm{m}$ in the Rumpi Hills. Females (12) in reproductive condition were mist-netted at IRS in March (6), April (1), May (3), August (1) and December (1), indicating that the species may breed throughout the year. Observers: J.T., P.A., S.N.S. and co-workers, P.A.D., P.R.

Red-headed Rockfowl Picathartes oreas*: RS, $\mathrm{u}(\mathrm{N}), \mathrm{u}(\mathrm{S})$; threatened. This primary forest species has an RDB status of "Rare" (Collar and Stuart 1985), although recent fieldwork has revealed it to be more widespread and perhaps locally commoner than was previously known (see Ash 1991). Within the Korup area it is known from the Rumpi Hills (Stuart 1986), from the north of KNP in the mountains near Esukutang, from hills near Nguti, and from a $50 \mathrm{~km}^{2}$ area in the south of KNP. This last area is rolling hills in forest with elevations up to $550 \mathrm{~m}$, covered with huge boulders, piles of rocks and associated caves. During August-November 1993 A.A.G. discovered a half-dozen significant nesting sites, the most important of which had over 30 nests on a boulder-covered knoll. Some of these nests were low enough to be inspected: five held two eggs each and two held three. At another site on a hill, one nest with two eggs in early September, $1.9 \mathrm{~m}$ above ground on the side of a boulder, was destroyed by chimpanzees Pan troglodytes, rebuilt in October, destroyed again, rebuilt a third time in November and two more eggs laid, then destroyed for a third time by chimpanzees. Many nests were higher up on the boulders (5-10 $\mathrm{m}$ ) and were safe from chimpanzees and drills Papio leucophaeus. A survey of this threatened species in KNP/KPA is needed. Observers: J.T., P.A., P.R., A.A.G.

Garden Warbler Sylvia borin: PM, u(S). Reports for KNP are from Mundemba in the south. Elsewhere in the KPA P.R. recorded it in small numbers in the Rumpi Hills, as did Stuart (1986). This migrant is present in Cameroon from September to April (Louette 1981a). Observers: P.A.D., A.A.G., P.R.

Willow Warbler Phylloscopus trochilus: PM, $\mathrm{u}(\mathrm{N}), \mathrm{u}(\mathrm{S})$. Observations come from KNP, Nguti and the Rumpi Hills, where P.R. recorded the species as did Stuart (1986). Observers: many.

Wood Warbler Phylloscopus sibilatrix: PM, $\mathrm{u}(\mathrm{N}), \mathrm{u}(\mathrm{S})$. Normally found in secondary habitats and villages, but observed twice at the edge of small primary forest 
clearings at IRS. Other records come from Mundemba, Nguti and the Rumpi Hills. Serle (1965) stated that the species occurs at Kumba from November to April. Observers: P.A., P.S. and co-workers, P.A.D., A.A.G., P.R.

Chattering Cisticola Cisticola anonyma: $R S, f(N), f(S)$. Common and widespread in secondary habitats and villages. Observers: P.S. and co-workers, P.A.D., A.A.G., P.R.

White-chinned Prinia Prinia leucopogon: RS, $r(S)$. Seemingly rare in the KNP area, but possibly overlooked. In the Rumpi Hills P.R. recorded it as did Stuart (1986), who reported several birds per observer per day. The western limit of this species's range is located just west of Korup in Nigeria (Elgood 1982). Observers: P.A., P.R.

Banded Prinia Prinia bairdii*: RS, u(N), r(S). This species is near the western limit of its range and there are few records from Nigeria (Elgood 1982). In the Rumpi Hills it is common above $900 \mathrm{~m}$ in farms and forest clearings. However, in the lowlands of KNP it is fairly scarce. P.R. recorded it twice at Baro and once at Nguti. Observers: P.A., P.A.D., P.R.

Black-capped Apalis Apalis nigriceps*: RS, $\mathrm{f} / \mathrm{c}(\mathrm{N}), \mathrm{f} / \mathrm{c}(\mathrm{S})$. Seen singly or in small groups in the canopy of lowland forests of Korup, and often in mixed-species flocks. It was in forest clearings and especially in logged forest near Baro. Observers: P.A., P.A.D., P.R.

Yellow-chested Apalis Apalis flavida: RS, r(S). Although noted for Cameroon by Serle and Morel (1977), no locality was given and no records were found in extensive material published by Serle concerning western Cameroon. Records by P.A. and T.G. therefore appear to be the first for Cameroon (Dejaifve 1991), fulfilling a prediction in Louette (1981a). Since it inhabits mangroves in Nigeria (Elgood 1982) it may be commoner in the south of KNP/KPA. Observers: P.A., T.G.

Buff-throated Apalis Apalis rufogularis*: RS, c(N), c(S). A common bird of mixedspecies flocks in lowland primary forest, forest edge and logged forest in KNP/KPA. In the south of KNP Stuart (1986) reported seeing three to six birds per observer per day. P.R. observed it in RHFR up to 1,200 $\mathrm{m}$ and at NAFR. Two immatures were seen with adults in early June 1992. Observers: P.A., S.N.S. and co-workers, P.A.D., P.R.

Yellow-browed Camaroptera Camaroptera superciliaris*: RS, $\mathbf{f} / \mathbf{c}(\mathbf{N} \& \mathrm{~S})$. A species of secondary forest and farm-bush which was also found in the lower strata of primary forest, where it seemed very uncommon. It was not observed in RHFR above $1,000 \mathrm{~m}$. P.A.D. noted nest-building in late January 1991 in the north of KNP. Observers: many.

Olive-green Camaroptera Camaroptera chloronota*: RS, c(N), c(S). Found in tangles of the middle and lower strata of lowland primary and secondary forest 
in Korup. A female with two immature birds were netted in early July 1992 near Baro. Observers: P.A., T.G., P.S. and co-workers, P.A.D., P.R.

Grey-backed Camaroptera Camaroptera brachyura:RS, f/c(N), f/c(S). A common species of villages and farms, widespread in the Korup area and found in villages at 1,000 $\mathrm{m}$ in the Rumpi Hills. Observers: P.A.D., A.A.G., P.R.

Brown-crowned Eremomela Eremomela badiceps*: RS, u(N), u(S). Recorded in logged forest and farms near Baro on several occasions, and also in the vicinity of Nguti. It was not recorded in NAFR or RHFR. P.A.D. observed juveniles being fed by adults in late January 1991, and Serle (1965) collected a juvenile in December at Limbe. Observers: P.A., T.G., P.A.D., A.A.G., P.R.

Green Crombec Sylvietta virens*: RS, $\mathrm{f} / \mathrm{c}(\mathrm{N}), \mathrm{f} / \mathrm{c}(\mathrm{S})$. A bird of secondary forest and farms which is widespread in the Korup area. It was found in RHFR up to 1,100 m. Observers: P.A., P.A.D., A.A.G., P.R.

Lemon-bellied Crombec Sylvietta denti*: RS, $\mathrm{u}(\mathrm{N}), \mathrm{d}(\mathrm{S})$. There are few records of this species in KNP/KPA. P.R. found it uncommon in the subcanopy of primary and logged forest, but it may be commoner than records suggest. It was noted on several occasions at IRS, Baro and once at 1,100 $\mathrm{m}$ in NAFR. All records involve mixed-species flocks. Observers: P.A., P.R.

Grey Longbill Macrosphenus concolor*: RS, c(N), c(S). Found in the middle strata of primary forest, forest edge, and secondary forest, often in mixed-species bird flocks. It was recorded in all lowland areas surveyed in Korup and was seen in NAFR up to 1,100 m. Observers: P.A., P.S. and co-workers, P.A.D., P.R.

Yellow Longbill Macrosphenus flavicans*: RS, $f(N), f(S)$. Found in the lower and middle strata of primary and logged forest in KNP/KPA, but less common than M. concolor. P.R. observed a bird carrying nest material in early December at IRS, and Serle $(1964,1981)$ mentions females in breeding condition in May and July. Observers: J.T., P.A., P.A.D., P.R.

Kemp's Longbill Macrosphenus kempi*: RS, r(N); RDB candidate. On 30 May 1992 a bird was seen and heard in old secondary forest in the north of KNP, 2 km west of Baro. S. Keen noted the species in the same general area in 1993 (C. Bowden in litt.). P.R. had a probable observation about $2 \mathrm{~km}$ east of the first sighting on 12 June 1991. These records represent the first for Cameroon. Some ornithologists have considered $M$. kempi conspecific with $M$. flavicans; however, because the species are sympatric in Korup, no hybrids have been reported and the songs of the two seem quite different, the case for considering the two as distinct is greatly fortified. The song of this bird was a series of about eight clear whistles rising slightly in pitch; in Korup $M$. flavicans typically gives a descending series of whistles, very much like that of a Brown-chested Alethe Alethe poliocephala. Observers: E. Bowden, C. Bowden, S. Keen, P.R. 
Green Hylia Hylia prasina*: RS, c(N), c(N). A species of primary forest and forest edge which was recorded in all localities surveyed, except above $1,300 \mathrm{~m}$ in RHFR. Found in mixed-species flocks in the middle and lower strata of the forest. At IRS females in breeding condition were caught in March and April, and a juvenile with an unossified skull was captured in early April. Observers: many.

Tit Hylia Pholidornis rushiae*: RS, $\mathrm{u}(\mathrm{N}), \mathrm{u}(\mathrm{S})$. All observations were in exploited forest and forest edge. Although widely recorded in KNP/KPA, it seems rather scarce throughout, usually being seen in small groups in the middle strata of the forest, often in the company of other insectivorous birds. Observers: P.A., T.G., P.A.D., P.R.

Spotted Flycatcher Muscicapa striata: $\mathrm{PM}, \mathrm{u}(\mathrm{N}), \mathrm{f}(\mathrm{S})$. This Palearctic migrant is present during the dry season and has been recorded from late September to April. It was found in forest clearings, farms and villages. Observers: P.A., P.A.D., A.A.G., P.R.

Cassin's Grey Flycatcher Muscicapa cassini*: RS, $c(N), c(S)$. Common along rivers and large streams in or near forest, widespread in KNP/KPA and recorded up to $1,200 \mathrm{~m}$ in RHFR. P.A.D. noted adults feeding juveniles in January and March and a juvenile was netted at IRS in May. Observers: many.

Yellow-footed Flycatcher Muscicapa sethsmithi*: RS, $f(N), f(S)$. A bird of treefall gaps and small forest clearings, often near streams. It is widespread in $\mathrm{KNP} / \mathrm{KPA}$, but its density is rather low. Usually seen alone or in pairs. Nest building has been recorded at IRS from December to April. Adults were seen feeding nestlings also from December to April, and a juvenile with buffy-tipped wing-coverts was netted in late March at IRS. Observers: many.

Little Grey Flycatcher Muscicapa epulata*: RS, r(S). Probably rare in KNP/KPA, but possibly overlooked because of similarity to $M$. sethsmithi. P.A. recorded it twice in Korup. Louette (1981a) mentions it for Upper Guinean forests in Cameroon, but there are very few reports for western Cameroon. Observer: P.A.

Olivaceous Flycatcher Muscicapa olivascens*: RS, u(N), u(S); RDB candidate. Recorded in primary forest and small forest clearings in KNP. In the south of KNP Thomas (1991) once captured three birds, and P.R. observed an individual there in September 1992. In the north of Korup P.R. recorded it on three occasions at IRS. In February 1992 a juvenile with buffy-tipped wing-coverts was observed in the company of an adult. Observers: J.T., P.A., P.R.

Ashy Flycatcher Muscicapa caerulescens ${ }^{*}$ RS, $r(S)$. It is curious that this species should be fairly common in the Rumpi Hills while there are so few records for KNP. P.R. observed it in farms between 1,00o and 1,250 m near Dikome Balue where it was also reported by Stuart (1986). Observers: P.A., P.R. 
Grey-throated Tit-flycatcher Muscicapa griseigularis*: RS, $r(S)$. This species seems rare in KNP/KPA. Louette (1981a) states that it is known from only a few localities in the Cameroon forest. A tape-recorded song of this species from Nguti was identified by C. Chappuis (in litt. 1993). Observers: P.A., P.R.

Dusky Blue Flycatcher Muscicapa comitata*: RS, $u(N), u(S)$. Observed infrequently in the lowland forest of KNP. Thomas (1991) mist-netted it only once and it was never captured at IRS. In the Rumpi Hills it is commoner and is found in farms and young secondary forest. In RHFR at 1,200 m P.R. observed a pair feeding recently hatched young in an old Ploceus weaver nest in early November 1991. Observers: J.T., P.A., P.A.D., A.A.G., P.R.

Sooty Flycatcher Artomyias fuliginosa*: RS, f/c(N), $f(S)$. Found in forest edge and logged forests in the lowlands of KNP/KPA. Serle (1954) recorded it at about 1,400 m near Dikome Balue. Observers: P.A., P.A.D., A.A.G., P.R.

Grey Tit-flycatcher Myioparus plumbeus: RS, r(N), r(S). Recorded (in quick succession) twice in farms at Baro, once at Nguti and once near Mundemba. Apparently the only other record for the Southwest Province is by Serle (1950), who collected a bird at Kumba. P.A.D. made an observation of this species near Ekondo Titi in late March 1991. It seems this species has been overlooked by observers and it may not be rare. Observer: P.R.

Fraser's Forest Flycatcher Fraseria ocreata*: RS, f(N), u(S). Found in small groups in lowland primary and secondary forest and forest edge, typically in the midstrata or canopy. In primary forest near IRS it seemed very uncommon, but in logged forest near Baro it was fairly common. It was not seen in RHFR and NAFR above 1,000 m. P.R. observed nest building by three individuals in logged forest near Baro on 19 March 1992. These birds made repeated trips with nest material to a dead tree surrounded by bare ground in a clearing, the nest being wedged between the tree-trunk and a piece of exfoliating bark. That three birds were participating suggests cooperative breeding. Observers: many.

White-browed Forest Flycatcher Fraseria cinerascens*: RS, u(N), u(S). Found along rivers and large streams. Most observations have come from the south of KNP where Addison et al. (1988) mist-netted four birds and Thomas (1991) caught several. Fewer reports come from the north of KNP. There is one record from Nguti. Observers: many.

Black Flycatcher Melaenornis edolioides: RS, r(S). Only one observer has reported this species for Korup. Although its occurrence in the lowland forest zone seems unusual, there are recent reports from Limbe by P.A.D. and C. Bowden (verbally 1992). Observer: P.A.

Pale Flycatcher Bradornis pallidus: RS, $r(S)$. This species has been recorded in the south of Korup. It is known primarily from non-forest areas of Cameroon (Louette 1981a). Observer: P.A. 
Violet-backed Flycatcher Hyliota violacea*: RS, r(N); RDB candidate. Louette (1981a) states that this flycatcher is unknown in Cameroon north of the Sanaga River. P.A.D.'s observation of one in a cleared area near Ikenge village is thus apparently the first for the Southwest Province of Cameroon. However, there is a recent report from nearby Mt Kupe (Nyassosso) by C. Bowden (verbally 1992). Observer: P.A.D.

Shrike Flycatcher Megabyas flammulata*: RS, $\mathrm{u}(\mathrm{N}), \mathrm{d}(\mathrm{S})$. Widespread but at low densities in primary and exploited forests of KNP/KPA, usually in small groups at the edges of clearings and treefall gaps, in the middle or upper forest strata. It was observed at the peak of Mt $\mathrm{Nta}$ Ali in NAFR at 1,266 m. Observers: P.A., P.A.D., P.R.

Black-and-white Flycatcher Bias musicus*: RS, $f(N), f(S)$. Recorded in secondary habitats and forest edge in KNP/KPA, and frequently noted in oil-palm plantations near Mundemba by A.A.G. and P.A.D. P.R. recorded it at Nguti and in RHFR at $1,100 \mathrm{~m}$, where a female was observed on a nest in second growth at Dikome Balue in early March 1992. P.A.D. noted an adult feeding young in late March in the south of KNP. Observers: P.A., P.A.D., A.A.G., P.R.

Scarlet-spectacled Wattle-eye Platysteira cyanea*: RS, $\mathrm{f}(\mathrm{N}), \mathrm{c}(\mathrm{S})$. A species of farms and secondary habitats. In KNP/KPA it is commonest in larger villages like Mundemba and Dikome Balue; in small forest villages in the north of KNP it is less common. Observers: P.A., T.G., P.A.D., A.A.G., P.R.

Chestnut Wattle-eye Platysteira castanea*: RS, $c(N), c(S)$. Found in primary and exploited forests, and forest edge. It is common throughout KNP/KPA, but less so in areas above $1,000 \mathrm{~m}$ in RHFR. It is usually seen in the lower forest strata in pairs or small groups, sometimes within mixed-species flocks. Females in reproductive condition were netted in March (2) and August (1) at IRS. P.A.D. recorded nest building in January and March. Observers: many.

White-spotted Wattle-eye Platysteira tonsa*: RS, $\mathrm{f}(\mathrm{N}), \mathrm{f}(\mathrm{S})$; RDB candidate. Fairly common in lowland primary forest and forest edge, usually in pairs or small groups in the middle and upper forest strata, often within mixed-species flocks. Observed in NAFR at 1,00o m. In May and June 1992 P.R. encountered four family groups in KNP and Nguti. In most groups both parents were seen feeding 1-3 juveniles. Observers: many.

Yellow-bellied Wattle-eye Platysteira concreta*: RS, $\mathbf{u} / \mathbf{f}(\mathrm{N}), \mathbf{u} / \mathbf{f}(\mathrm{S})$. Widespread but thinly distributed in KNP/KPA, in the understorey of primary and exploited forests, usually in single-species groups, but also in association with other bird species. A total of 12 birds were captured at IRS and near Baro by P.A.D. and P.R., and approximately 20 have been caught in the south of KNP (Anon. 1989, Thomas 1991). P.R. observed three juveniles being fed by adults at $1,200 \mathrm{~m}$ in NAFR in late April 1992. Another juvenile and a female with a brood-patch were netted near Baro in July 1992. Birds captured at Baro and IRS were the 
subspecies kumbaensis. In Nigeria the species is only known from the extreme south-east (Elgood 1982). Observers: J.T., P.A., P.A.D., P.R.

Chestnut-capped Flycatcher Erythrocercus mccalli*: RS, f/c(N), f(S). A species of primary and secondary forests and forest edge, occurring in small groups within mixed-species flocks in the middle and upper strata. It was found in all areas of KNP/KPA which were surveyed, but it was absent from areas above $1,300 \mathrm{~m}$ in RHFR. Observers: P.A., T.G., P.A.D., A.A.G., P.R.

Blue Flycatcher Trochocercus longicauda: $\mathrm{RS}, \mathrm{r}(\mathrm{S})$. There are very few reports in the lowland parts of KNP/KPA, where it seems rare. However, in farms and villages in RHFR above $1,000 \mathrm{~m}$ it is quite common; P.R. observed a pair building a nest there in early March 1992. Observers: P.A., T.G., P.R.

Blue-headed Crested Flycatcher Trochocercus nitens*: RS, u(N), u(S). Although widespread in the Korup area, this species occurs in low densities. Recorded at NAFR, RHFR (at 1,300 m) and in the north and south of KNP. Other reports from the south of KNP (Stuart 1986, Thomas 1991) also indicate that it is rather scarce. Observed in the lower strata of primary forest both singly and in pairs, as well as within mixed-species flocks. In early March 1992 a pair was seen feeding a fledgling at 1,300 $\mathrm{m}$ in RHFR. Observers: many.

Dusky-crested Flycatcher Trochocercus nigromitratus*: RS, $f(N), f(S)$. Common in the forest understorey, where seen singly and in pairs. In the Rumpi Hills it is replaced above $1,000 \mathrm{~m}$ by $T$. albiventris. Females in breeding condition (4) were netted at IRS in March (1), April (1), July (1) and December (1), and a juvenile was captured with an adult female in mid-March 1991. This indicates that the species may breed year-round. Observers: many.

Red-bellied Paradise-flycatcher Terpsiphone rufiventer*: RS, c(N \& S). Among the commonest of Korup's lowland forest birds. It frequents the lower and middle strata of primary and secondary forests and forest edge, often within mixedspecies flocks. In more open habitats such as farms it is replaced by T. rufocinerea. It was present in RHFR up to $1,300 \mathrm{~m}$, but at much lower densities. P.A.D. recorded nest building in early January, and a female with a brood-patch was captured at IRS in late March 1991. Observers: many.

African Paradise-flycatcher Terpsiphone viridis: RS/AM, $r(N), u(S)$. There are few records in KNP/KPA. A.A.G. observed birds of a white-tailed form (see Louette 1981a) near Mundemba on 16 June and 17 August 1992. Stuart (1986) reported it daily in small numbers in March 1984 in the Rumpi Hills near Dikome Balue. Observers: P.A.D., A.A.G.

Rufous-vented Paradise-flycatcher Terpsiphone rufocinerea*: RS, $u(N), u(S)$. Observed in KNP at Baro and Mundemba. Other records in KPA come from Nguti and RHFR where the species is fairly common. Although primarily a bird of second growth, it was recorded in primary forest edge of RHFR up to c. $1,350 \mathrm{~m}$. Observer: P.R. 
Dusky Tit Parus funereus*: RS, r(N), r(S). In Cameroon this is a scarce forest species for which there are few records (Louette 1981a). P.A.D. recorded it in the north of KNP in exploited forest near Ikenge village. Observers: P.A., P.A.D.

Brown Sunbird Anthreptes gabonicus*: RS, u(S). All reports in the Korup area are from southern KNP, where P.A. found it regularly in the forest canopy. Louette (1981a) states that it is found in mangroves and the adjacent forest district. It could occur in the north of KNP where P.R. had two possible sightings. Observers: J.T., P.A., T.G., P.S. and co-workers.

Fraser's Scarlet-tufted Sunbird Anthreptes fraseri*: RS, c/a(N \& S). Among the commonest birds in the lowland forests of KNP/KPA. It is found in the lower to middle forest strata in small groups, often within mixed-species flocks. Family groups were observed in February 1991 at IRS, and a breeding-condition female and a juvenile were captured in March 1991. Serle (1950, 1965) mentions two females collected in breeding condition at lowland localities in October. Observers: many.

Green Sunbird Anthreptes rectirostris*: RS, $\mathrm{u} / \mathrm{f}(\mathrm{N}), \mathrm{u} / \mathrm{f}(\mathrm{S})$. Found in primary and secondary forest, forest edge and farms. It was uncommon in the lowlands of KNP, but in secondary habitats in the Rumpi Hills it is fairly common. Other sightings come from IRS, Nguti and NAFR, where P.R. recorded it at $1,250 \mathrm{~m}$. Observers: P.A., T.G., P.A.D., P.R.

Violet-tailed Sunbird Anthreptes aurantium*: RS, u(S). There are few observations within KNP and all are from the south. Near Mundemba, P.A.D. recorded it once on the Ndian River and A.A.G. found it uncommon in farmland. In Korup it is at the westernmost limit of its range, Elgood (1982) having rejected reports from Nigeria. Observers: P.A.D., A.A.G.

Collared Sunbird Anthreptes collaris*: RS, c(N), c(S). Common in secondary forests and farms of KNP/KPA, seemingly less so in primary forest. Seen in pairs or small groups, and sometimes in mixed-species flocks. Stuart (1986) and P.R. recorded the species up to 1,400 $\mathrm{m}$ in the Rumpi Hills. Observers: many.

Little Green Sunbird Nectarinia seimundi*: RS, $u(N), u(S)$. Assessment of abundance in KNP/KPA is difficult given the similarities to $N$. batesi. However, the race present in the Korup area, N. s. minor, is yellower in the underparts and brighter olive-green above than $N$. batesi. $N$. seimundi was observed in forest clearings and second growth. Observers: P.A., P.R.

Bates's Sunbird Nectarinia batesi ${ }^{*}$ : RS, $\mathbf{u} / \mathbf{f}(\mathrm{N}), \mathbf{u} / \mathbf{f}(\mathrm{S})$. Assessment of abundance is difficult given the similarities to N. seimundi. However, N. batesi seems somewhat commoner than $N$. seimundi in KNP/KPA. P.R. observed adults feeding two recently fledged juveniles at IRS in late August 1991. The species was seen at forest edge, forest clearings and tree-fall gaps in the north and south of KNP, 
and at Nguti, Baro, and RHFR. Stuart (1986) reported it in moderate numbers in the Rumpi Hills. Observers: J.T., P.A., P.R.

Olive Sunbird Nectarinia olivacea*: RS, c(N), c(S). A common and widespread species of primary and secondary forests in Korup, found primarily in the understorey and not associating strongly with mixed-species flocks. Nests were found at IRS in February, March and June. In logged forest near Baro in July $50 \%$ of 28 birds caught were juveniles. Observers: many.

Reichenbach's Sunbird Nectarinia reichenbachii ${ }^{*}$ : RS, $r(S)$. The one record in Korup comes from Smith (1989), who observed it in the south of KNP. Eisentraut (1963) and Serle (1965) collected a fairly large number around Mt Cameroon. More records in the Korup area may be expected. Observers: P.S. and co-workers.

Olive-backed Sunbird Nectarinia verticalis*: RS, $f(S)$. In the south of KNP near Mundemba A.A.G. has found this sunbird frequent. It was fairly common in farms around RHFR and was also observed at Nguti. There are no observations yet in the north of KNP. Observers: P.A., A.A.G., P.R.

Blue-throated Sunbird Nectarinia cyanolaema*: RS, $\mathrm{u} / \mathrm{f}(\mathrm{N}), \mathrm{u}(\mathrm{S})$. A sunbird of primary and secondary forests and farms. In forest it frequents the middle strata. It was commonest in RHFR where P.R. observed up to 15 birds in a day in farms near Dikome Balue. At IRS nest building was observed by P.A.D. and P.R. in late November and January. A juvenile male was captured in early April 1991 at IRS. Observers: J.T., P.A., S.S. et al., P.A.D., P.R.

Carmelite Sunbird Nectarinia fuliginosa*: RS, $\mathbf{u}(\mathrm{S})$. Serle (1954) states that this sunbird has a strong preference for "maritime habitat" in western Cameroon, being common in the coastal plain adjacent to Mt Cameroon, but apparently absent from the forest interior. A.A.G. found it uncommon in farmland in the Mundemba area, but it is unknown in the north of Korup. Observers: P.A., A.A.G.

Green-throated Sunbird Nectarinia rubescens*: RS, r(S). Although considered abundant at Limbe and Kumba (Serle 1965), there are surprisingly few observations for KNP/KPA. A.A.G. has found it rare near Mundemba. There are no records to date for the north, though it should occur. This species is at the western limit of its range (Louette 1981a). Observers: P.A., A.A.G.

Olive-bellied Sunbird Nectarinia chloropygia*: RS, c(N), c(S). Common throughout KNP/KPA in villages and farms. Observers: many.

Tiny Sunbird Nectarinia minulla*: RS, r/d(N), r/d(S). Given the similarity to $N$. chloropygia, its abundance in KNP/KPA is uncertain. It has probably been underrecorded. Serle (1965) considered it fairly common at Limbe in secondary forest and thickets and he also collected it at Dikome Balue in the Rumpi Hills. P.A.D. 
and P.R. had several probable observations in the north and south of KNP. Observers: P.A., P.A.D., P.R.

Johanna's Sunbird Nectarinia johannae*: RS, $u(N), u(S)$. This species seems uncommon in KNP/KPA, but because it frequents the forest subcanopy it may have been overlooked. P.R. recorded it in primary forest at IRS and in logged forest near Baro. Other records are from the south of KNP and Dikome Balue in the Rumpi Hills (Serle 1954). Observers: P.A., P.S. and co-workers, P.R.

Superb Sunbird Nectarinia superba*: RS, $f / c(N), f(S)$. A sunbird of secondary forest, forest edge and farms, widespread in KNP/KPA and commonest in RHFR. It seems to be absent from primary forest where it may be replaced by $N$. johannae. Specimens collected by Serle (1965) in the general area were considered $N$. s. superba, but showed some intergradation with $N$. s. nigeriae. Observers: P.A., P.S. and co-workers, P.A.D., A.A.G., P.R.

Yellow White-eye Zosterops senegalensis: $R S, r(N), u(S)$. The only records in KNP are by A.A.G. who has found it uncommon in the Mundemba area. Other locations in the KPA include Nguti and RHFR. It is uncommon in the lowlands where it was absent in forest and only observed in second growth. In RHFR it is common and was observed in forest up to $1,650 \mathrm{~m}$. Observers: A.A.G., P.R.

Green-backed Twinspot Hypargos nitidulus*: RS, r(N), r(S). This species has been noted infrequently in KNP/KPA, though it may be commoner than the small number of records suggests. P.R. found it near villages and along roads in the Rumpi Hills, and at Nguti and Baro. P.A.D. recorded it at Ikenge village. Observers: P.A., P.A.D., P.R.

Black-bellied Seed-cracker Pirenestes ostrinus*: RS, u(S). All records thus far come from the south of KNP where A.A.G. found it uncommon along streams in oil-palm plantations near Mundemba. Observers: P.A., A.A.G.

Grey-crowned Negro-finch Nigrita canicapilla*: RS, c(N), c(S). A species of primary and secondary forest, forest edge and farms. In forest it was found in the middle and upper strata. It is widespread in KNP/KPA and has been recorded in RHFR and NAFR. Nest building was observed in April and June. Near Baro in early June P.R. found a dead female in a nest with three eggs which had fallen during a storm. Observers: J.T., P.A., P.A.D., A.A.G., P.R.

Pale-fronted Negro-finch Nigrita luteifrons ${ }^{*}: \mathrm{RS}, \mathrm{r}(\mathrm{S})$. There are few records to date within KNP/KPA. The only reports for KNP come from the south. P.R. observed it once at Nguti where it seemed rare. At Limbe it was considered "not uncommon" by Serle (1965), also by P.A.D. in early April 1991. Observers: P.A., P.S. and co-workers, P.R.

Chestnut-breasted Negro-finch Nigrita bicolor*; RS, $\mathrm{u}(\mathrm{N}), \mathrm{u}(\mathrm{S})$. A species of primary and secondary forest, forest clearings and farms, infrequently encountered 
but recorded widely. Found in the lower and middle forest strata. A juvenile was seen in late July near Baro. Observers: J.T., P.A., P.A.D., P.R.

White-breasted Negro-finch Nigrita fusconata*: RS, r(S). There are surprisingly few records in KNP/KPA. P.R. observed a pair in second growth near Mundemba in September 1992 and recorded the species on several occasions at forest edge near Nguti, where it is uncommon. Observer: P.R.

Flower-pecker Weaver-finch Parmoptila woodhousei*: RS, $\mathrm{u}(\mathrm{N}), \mathrm{u}(\mathrm{S})$. This species was found in nearly all areas surveyed within KNP/KPA, singly and in small groups, often within mixed-species flocks, in the lower strata of primary and secondary forest and forest edge. In RHFR it occurred up to 1,250 m. Observers: J.T., P.A., S.N.S. and co-workers, P.A.D., P.R.

Bluebill Spermophaga haematina*: RS, $\mathrm{u} / \mathrm{f}(\mathrm{N}), \mathrm{u} / \mathrm{f}(\mathrm{S})$. A species of secondary forest thickets, farms and, less commonly, primary forest. In primary forest at IRS it was captured on only three occasions. A female with a brood-patch was captured near Baro in early July and a juvenile was netted at IRS in July. Observers: many.

Orange-cheeked Waxbill Estrilda melpoda: RS, a(S). An abundant species of open grassy areas near towns and villages and along roads, although not found in smaller villages surrounded by lowland forest. During the wet season months of August and September P.R. observed many juveniles in flocks with adults at Nguti. Observers: P.A., P.S. and co-workers, P.A.D., A.A.G., P.R.

Black-crowned Waxbill Estrilda nonnula: RS, c(S). Frequents grassy areas in farms and villages and is widespread in the KPA outside KNP. In KNP it is common in the Mundemba area. It is at the western limit of its range and occurs in Nigeria only on the Obudu and Mambilla Plateaus (Elgood 1982). Observers: P.A., P.A.D., A.A.G., P.R.

Black-headed Waxbill Estrilda atricapilla: RS, d(S). A species of villages, farms and roadsides which is known from the Mundemba area but not from the north of KNP. Although in most localities $E$. nonnula was much commoner than $E$. atricapilla, in the Nguti area the reverse was true. In late June 1992 juveniles were seen in a flock of adults there. Observers: P.A.D., A.A.G., P.R.

Common Waxbill Estrilda astrild: RS, r(N), r(S). P.A. noted this bird in the Mundemba area. P.R. observed one individual at Baro in the north of KNP in July 1992. The species is apparently scarce in the Korup area. Observers: P.A., P.R.

Black-and-white Mannikin Lonchura bicolor: $\mathrm{RS}, \mathrm{c}(\mathrm{N})$, $\mathrm{a}(\mathrm{S})$. Common in villages and farms in the Korup area, frequenting larger open grassy areas of KNP/KPA. However, unlike other estrildid finches it was observed in small forest villages like Baro. In Nguti P.R. saw many juveniles in flocks with adults in September. Observers: P.A., P.S. and co-workers, P.A.D., A.A.G., P.R. 
Bronze Mannikin Lonchura cucullata: $\mathrm{RS}, \mathrm{c}(\mathrm{S})$. A species of villages and roadsides which is commonly recorded in KNP/KPA. There are no records from the north of KNP, perhaps owing to a scarcity of appropriate habitat. In Nguti P.R. observed birds building nests during most months of the wet season. Observers: P.A., P.S. and co-workers, P.A.D., A.A.G., P.R.

Grosbeak Weaver Amblyospiza albifrons: $\mathrm{RS}, \mathrm{r}(\mathrm{N})$. There is only one record for the entire KNP/KPA: a female at Baro in the north of KNP in August 1992. Observer: P.R.

Orange Weaver Ploceus aurantius: $\mathrm{RS}, \mathrm{u}(\mathrm{S})$. Observations come only from the Mundemba area in the south of KNP. It was seen on the banks of the Ndian River by P.A.D., and A.A.G. recorded it along the Mana River. Observers: P.A.D., A.A.G.

Village Weaver Ploceus cucullatus: $\mathrm{RS}, \mathrm{c}(\mathrm{N}), \mathrm{a}(\mathrm{S})$. Common in villages and farms, and widespread in $\mathrm{KNP} / \mathrm{KPA}$. It was not recorded in the Rumpi Hills above 1,00o m. Observers: many.

Viellot's Black Weaver Ploceus nigerrimus: RS, $c(N), c(S)$. This species frequents villages and farms and is known throughout KNP/KPA. Smaller numbers were seen at higher elevations in villages in the Rumpi Hills. It is possible that flocks recorded in forest by Thomas (1991) were actually the very similar $P$. albinucha. Observers: many.

Yellow-mantled Weaver Ploceus tricolor ${ }^{*}: \mathrm{RS}, \mathrm{u}(\mathrm{N}), \mathrm{r}(\mathrm{S})$. There are few records in KNP/KPA. P.A.D. observed it at Baro and Ikenge, and P.R. recorded it twice near Baro and once near Osirayib, $17 \mathrm{~km}$ east of Baro. In late July 1992 one bird at Baro seemed to be associated with a nearby freshly built weaver nest, but this was never confirmed. Observers: P.A., P.A.D., P.R.

White-naped Weaver Ploceus albinucha*: RS, r/d(N), r/d(S). There are few reports for the Korup area, and apparently even fewer for the rest of south-western Cameroon. Serle (1954) collected it once at Ekona, and Eisentraut (1963) collected it near Mt Cameroon. In KNP P.R. noted it on three occasions near Baro, where it was seen singly and in small groups. P.A. recorded it rarely in small groups in the forest canopy in the south of KNP. Given its similarity to $P$. nigerrimus, it may be overlooked. Observers: P.A., T.G., P.R.

Spectacled Weaver Ploceus ocularis: RS, d(S). Assessent of abundance in Korup is complicated by its similarity to $P$. nigricollis brachypterus, although an indication comes from Serle (1965) in the Southwest Province, who collected far fewer $P$. ocularis than $P$. nigricollis and considered the former somewhat uncommon. The westernmost records for this species come from the adjacent Oban sector of Cross River National Park in neighbouring Nigeria (Ash 1990). There is no definite record yet for the north of KNP/KPA, although it should occur there. Observers: P.A., P.A.D., A.A.G., P.R. 
Black-necked Weaver Ploceus nigricollis*: RS, d(S). A weaver of forest edge and secondary habitats which probably occurs throughout Korup, but there is no definite record yet for the north of KNP. The subspecies $P$. $n$. brachypterus is present in Korup but very similar in appearance to $P$. ocularis. Given that Serle (1950, 1965) collected a large number of $P$. nigricollis in the Southwest Province (mostly Limbe) and felt that $P$. ocularis was uncommon in western Cameroon, it seems very likely that the large majority of ocularis/nigricollis weavers in Korup are the latter. C. Bowden (verbally 1992) has studied plumage differences of both species at Mt Kupe and believes that most birds there are also nigricollis. He also reported seeing nigricollis near Mundemba. Observers: P.A., C. Bowden, P.R.

Golden-backed Weaver Ploceus preussi*: RS, r(S). The only record for KNP was by P.R. in farms near Mundemba on 2 October 1992. The only other record for the KPA comes from Serle (1954), who collected an individual at Dikome Balue near RHFR. Observer: P.R.

Red-vented Malimbe Malimbus scutatus*: RS, $f(N), f(S)$. Recorded widely in $\mathrm{KNP} / \mathrm{KPA}$ in primary and secondary forests and forest edge. It is less often seen in primary forest, where it remains in the canopy. In August 1992 P.R. observed several birds building a nest in Raphia palms at forest edge near Baro: two males and one female were seen to participate, while a second female was perched nearby. This species was not observed in RHFR and seems absent from higher elevations. Observers: P.A., P.A.D., A.A.G., P.R.

Rachel's Malimbe Malimbus racheliae*: RS, $\mathrm{c}(\mathrm{N}), \mathrm{c}(\mathrm{S})$; RDB candidate. This species frequents the lower and middle strata of primary forest and forest edge. In Korup it is perhaps the commonest Malimbus in lowland primary forest and is a regular member of mixed-species foraging flocks. At IRS nest building was observed in March, a female with a brood-patch was mist-netted in March, and juveniles were sighted with adults in July and August. The species is very near the western limit of its range, but there are a number of recent records from adjacent south-eastern Nigeria (Mackenzie 1979, Ash et al. 1989, Ash 1990). Observers: many.

Gray's Malimbe Malimbus nitens*: RS, $f(N), f(S)$. Found in lowland primary and secondary forests and forest edge in KNP/KPA, where it frequents the lower and middle strata, sometimes in mixed-species flocks. It was not recorded in RHFR above 1,000 $\mathrm{m}$. Nests were hung over slow-moving streams and areas with standing water. Most nest building at IRS occurred during the early wet season and a female with a brood-patch was captured there in late May. P.A.D. also noted nest building in December, and the feeding of young in January. At least seven nests were found at a pond with numerous dead trees in late May near Baro; it was not clear whether more than one pair of birds had built these nests. Observers: many.

Red-headed Malimbe Malimbus rubricollis*: RS, $\mathrm{u}(\mathrm{N}), \mathrm{u}(\mathrm{S})$. Observed occasionally in primary and logged forest, forest edge and in tall trees on farms, typically 
in the subcanopy. It is probably the least common of Korup's malimbes. Observers: many.

Red-bellied Malimbe Malimbus erythrogaster*: RS, u/f(N), u/f(S). P.A.D. considered this species fairly common in secondary forest and forest clearings, but also recorded it rarely in primary forest. P.R. noted it less frequently. Records in the north of KNP/KPA come from Baro, Ikenge and Nguti. Observers: P.A., P.S. and co-workers, P.A.D., P.R.

Crested Malimbe Malimbus malimbicus*: RS, $f(N), f(S)$. Widespread in lowland primary and secondary forest (usually the middle strata), more likely to be found at higher elevations than other Malimbus in Korup and the only Malimbus recorded at 1,000 $\mathrm{m}$ in NAFR or RHFR. Although Louette (1981a) states that it is the commonest Malimbus in the forests of Cameroon, M. racheliae is probably the commonest species in Korup. Observers: many.

Grey-headed Sparrow Passer griseus: RS, u(N), c/a(S). A species of towns and agricultural areas, and although typically absent from smaller villages surrounded by forest, P.A.D. observed it at Baro. It is commonest in the Mundemba area. Observers: P.S. and co-workers, P.A.D., A.A.G., P.R.

Pin-tailed Whydah Vidua macroura: RS, a(S). Found in villages and open grassy habitats, and considered abundant by A.A.G. in the Mundemba area. It has been recorded widely within the KPA, but there are no observations yet from smaller villages in the north of KNP. Observers: P.A.D., A.A.G., P.R.

Narrow-tailed Starling Poeoptera lugubris ${ }^{*}: \mathrm{RS}, \mathrm{u}(\mathrm{N}), \mathrm{u}(\mathrm{S})$. An uncommon species of primary and secondary forests and farms. In the north of KNP it has been seen at Baro and Ikenge. Thomas (1991) reported it from primary forest in the south of KNP. It is apparently much commoner at higher elevations, as P.R. regularly encountered it in secondary growth and forest edge in the Rumpi Hills from 1,000 to 1,300 $\mathrm{m}$. Stuart (1986) also recorded it as fairly common near Dikome Balue. Ash et al. (1989) found it fairly common in lowland forest at the Ikpan block and Oban West. Observers: J.T., P.A., P.A.D., P.R.

Chestnut-winged Starling Onycognathus fulgidus*: RS, $u(N), u(S)$. Uncommon in the Korup area, recorded by P.A.D. and P.R. in the north of KNP, while in the south a flock of five birds was noted by P.R. near Mundemba. It has been found in logged forest and forest edge. Observers: P.A.D., P.R.

Purple-headed Glossy Starling Lamprotornis purpureiceps*: RS, u(N \& S). This uncommon starling is found in primary and secondary forests in Korup. Records come from the north and south of KNP and the Rumpi Hills, where P.R. observed small flocks on several occasions near Dikome Balue, as did Stuart (1986). Observers: P.A., P.A.D., A.A.G., P.R.

Splendid Glossy Starling Lamprotornis splendidus*: RS, $u(N), \mathbf{u}(\mathrm{S})$. A species of forest edge and farms which seems erratic in its occurrence in the Korup area, 
sometimes not being recorded for several months (e.g. 1992 wet season). Although Elgood (1982) adduces no evidence of migration in Nigeria, the species may possibly make local movements in this area. P.A.D. observed a bird carrying nest material in January 1990, and Serle (1950) collected breedingcondition males in January at Kumba. Observers: P.A., T.G., P.A.D., A.A.G., P.R.

Eurasian Golden Oriole Oriolus oriolus: PM, r(S). There is one report of this Palearctic migrant for KNP/KPA: P.A.D. noted it on 22 March 1991 at forest edge near Mundemba. Records are few in the Southwest Province of Cameroon. Serle (1954) mentions two birds he collected at Ekona on 6 April. Observer: P.A.D.

Western Black-headed Oriole Oriolus brachyrhynchus*: RS, c(N \& S). Found in primary and secondary forest and forest edge in KNP/KPA, frequenting the middle strata and subcanopy. It is widespread in the lowlands, but in RHFR few were observed above $1,100 \mathrm{~m}$, and none was recorded above 1,300 $\mathrm{m}$ where the species was replaced by O. nigripennis. In late May 1992 P.R. observed an adult feeding a juvenile near Baro. Observers: many.

Black-winged Oriole Oriolus nigripennis*: RS, $r(S)$. Rare in the lowlands of KNP (so far all records are from the Mundemba area), but common in RHFR between 1,000 and $1,650 \mathrm{~m}$. Serle (1950) commented on the species's apparent preference for higher elevations in western Cameroon and reported that all nine birds he collected in the Northwest and Southwest Provinces were taken above $1,220 \mathrm{~m}$. Observers: P.A., P.A.D., A.A.G., P.R.

Square-tailed Drongo Dicrurus ludwigit*: RS, u(N), u(S). This uncommon species is found in primary and secondary forests of KNP/KPA. Thomas (1991) saw it several times in the south of KNP, while in the north it was recorded by P.A.D. and P.R. at IRS and in logged forests near Baro. Stuart (1986) noted small numbers between 1,00o and 1,300 $\mathrm{m}$ near Dikome Balue in the Rumpi Hills. Observers: J.T., P.A., P.S. and co-workers, P.A.D., P.R.

Shining Drongo Dicrurus atripennis*: RS, $c(N), c(S)$. A common species of primary and secondary forest and forest edge, typically staying in the lower and middle strata. P.R. observed it throughout KNP/KPA, but only up to $1,250 \mathrm{~m}$ in RHFR where it was much less common. P.A.D. noted a bird on a nest in mid-February 1991. Observers: many.

Velvet-mantled Drongo Dicrurus adsimilis*: RS, $f / c(N), f / c(S)$. Found in secondary forests, forest edge and farms with tall trees, but recorded only once at IRS, in the subcanopy of primary forest. Slightly less common than $D$. atripennis. On 7 April 1992 a bird was seen building a nest at forest edge near Baro. Serle (1954) collected females in breeding condition in November at Kumba and December at Dikome Balue. Observers: many. 
Pied Crow Corvus albus: RS, $\mathrm{c}(\mathrm{N})$, a(S). Found in villages, towns and plantations. Although absent from most smaller villages which are surrounded by forest, it has been recorded in the remote village of Esukutang in the north of KNP. It is most abundant in the south of Korup near Mundemba. P.A.D. noted nest building in December and incubation in early March. Observers: many.

\section{Birds of the Korup Project Area but not (yet) of Korup National Park}

Lanner Falcon Falco biarmicus. Recorded at Dikome Balue in the Rumpi Hills by Stuart (1986).

Cameroon Olive Pigeon Columba sjostedtit (RDB candidate). Endemic to montane forests of western Cameroon and the Obudu Plateau in Nigeria (Urban et al. 1986). Observations of this species by P.R. represent the first records for the Rumpi Hills. A total of five individuals were observed between 1,150 and $1,650 \mathrm{~m}$ in primary and secondary forest in RHFR. The possibility of confusion with Columba albinucha was ruled out.

White-naped Pigeon Columba albinuchat (Near-threatened). Eisentraut collected three individuals near Dikome Balue in the Rumpi Hills in 1967 (Stuart and Jensen 1986). Until recently, these were the only records in West Africa. However, C. Bowden and E. Bowden (verbally 1993) recently recorded the species at Mt Kupe.

Mottled Swift Tachymarptis aequatorialis. Stuart (1986) recorded this species near Dikome Balue in the Rumpi Hills.

Bar-tailed Trogon Apaloderma vittatumt. This montane species was recorded by P.R. daily in RHFR between 1,200 and 1,650 $\mathrm{m}$ with a high count of 12 individuals recorded in one day. A fairly common bird in primary and older secondary montane forest.

Grey-throated Barbet Gymnobucco bonapartei*. In Nguti on 13 September 1992 P.R. recorded 10 birds excavating nest cavities in a dead tree in second growth. The species has been recorded in several locations in the Southwest Province and is a likely addition to the KNP list. Serle (1950, 1954) collected 16 at Kumba and one at Massaka, which is very close to the RHFR/KPA border.

Western Green Tinkerbird Pogoniulus coryphaeust. P.R. recorded this species in small numbers in RHFR and NAFR. Stuart and Jensen (1986) reported slightly higher numbers from nearby Dikome Balue, calling it an adaptable species of montane primary forest, clearings and forest edge.

Yellow-footed Honeyguide Melignomon eisentraut* (Threatened). Serle (1965) tentatively identified a honeyguide collected at Bakebe (adjacent to NAFR) as Zenker's Honeyguide Melignomon zenkeri. However, this specimen was later attributed by Louette $(1981 \mathrm{~b})$ to the new species $M$. eisentrauti, which is known 
from only a few other sites in Liberia, Ghana and south-west Cameroon (Collar and Stuart 1985, Fry et al. 1988).

Green-backed Woodpecker Campethera cailliautii* ${ }^{*}$ Recorded by Stuart (1986) and P.R. near Dikome Balue in the Rumpi Hills.

Tullberg's Woodpecker Campethera tullbergit (RDB candidate). P.R. recorded this montane species daily in RHFR. All observations were between 1,200 and $1,650 \mathrm{~m}$ in primary or secondary forest.

Cardinal Woodpecker Dendropicos fuscescens. Recorded near Dikome Balue in the Rumpi Hills by Serle (1965), Stuart (1986) and P.R.

Elliot's Woodpecker Dendropicos elliotiit. This montane woodpecker is fairly common in RHFR between 1,000 and $1,650 \mathrm{~m}$. It was recorded mostly in primary and secondary forest, but was encountered in second growth, though not far from forest edge.

Grey-headed Broadbill Smithornis sharpei* (RDB candidate). Reported from the Rumpi Hills at Dikome Balue by Serle (1965).

Rock Martin Hirundo fuligula. P.R. recorded a small flock in RHFR near Dikome Balue where it was also recorded by Stuart (1986).

Ethiopian Swallow Hirundo aethiopica. Recorded at Nguti by P.R. where it was seen in small numbers and is apparently resident.

Common House Martin Delichon urbica. Six individuals were noted amongst a large flock of Hirundo rustica on 12 November 1991 at 1,600 m in RHFR. Records from Cameroon are few, but Stuart (1986) reported it at several locations in montane areas.

Tree Pipit Anthus trivialis. Records for this Palearctic migrant come from Dikome Balue in the Rumpi Hills (Stuart 1986) and Nguti where P.R. observed it on several occasions during the dry season of 1991-1992.

Petit's Cuckoo-shrike Campephaga petiti*. Fairly common in RHFR in forest and forest edge, but near the northern limit of its range as there are few Nigerian records (Keith et al. 1992).

Grey Cuckoo-shrike Coracina caesiat. Fairly common in the Rumpi Hills, restricted to montane primary and secondary forest. Observed between 1,200 and $1,650 \mathrm{~m}$ in RHFR and nearby areas.

Cameroon Montane Greenbul Andropadus montanust (Near-threatened). An endemic species of the montane forests of western Cameroon and eastern Nigeria (Keith et al. 1992). In RHFR it is fairly common in secondary montane forest and farms, an apparent preference also reported by Serle (1954), Hall and 
Moreau (1962) and Stuart and Jensen (1986). All sightings by P.R. were below $1,550 \mathrm{~m}$.

Mountain Greenbul Andropadus tephrolaemust. This species is common in RHFR in primary and secondary forest from 1,000 to $1,650 \mathrm{~m}$. In early November 1991 P.R. observed a pair building a nest at $1,600 \mathrm{~m}$.

Cameroon Olive Greenbul Phyllastrephus poensist (RDB candidate). This species is endemic to the montane forests of western Cameroon, eastern Nigeria and Bioko (Fernando Po) (Keith et al. 1992). It was recorded between 1,150 and $1,650 \mathrm{~m}$ in RHFR, and from 1,000 to $1,250 \mathrm{~m}$ in NAFR, in small groups in primary and secondary forest. In early March 1992 in RHFR two family groups were observed, with adults feeding recently fledged young.

Grey-headed Greenbul Phyllastrephus poliocephalust (Near-threatened). This greenbul is found only in the montane forests of western Cameroon and eastern Nigeria (Keith et al. 1992). It was common in RHFR between 1,200 and $1,650 \mathrm{~m}$ in primary and secondary forest and forest edge, P.R. observing it in flocks of up to 10 or more birds with a high day count of 30 birds. This is higher than the maximum of 15 per day given by Stuart and Jensen (1986).

Red-eyed Puffback Dryoscopus senegalensis*. Recorded in the Rumpi Hills near Dikome Balue by Serle (1965) and P.R.

Pink-footed Puffback Dryoscopus angolensist. Noted in small numbers in primary and secondary montane forest in RHFR. It was typically seen in pairs in mixedspecies flocks between 1,000 and 1,650 m. It was also observed in NAFR where it was fairly common above $1,000 \mathrm{~m}$.

Lühder's Bush-shrike Laniarius luehderi* ${ }^{*}$ Recorded in second growth at Dikome Balue by Stuart (1986) and P.R.

Fülleborn's Black Boubou Laniarius fuellebornit (RDB candidate). A common montane forest bird in RHFR. Birds frequented primary and secondary forest and thick second growth between 1,000 and 1,650 m. In RHFR one bird was netted with an active brood-patch in early March 1992.

Grey Bush-shrike Malaconotus bocagei* P.R. recorded this species in farms of the Dikome Balue area, as did Serle (1965) and Stuart (1986).

Green-breasted Bush-shrike Malaconotus gladiatort (Threatened). An endemic species of the montane forests of western Cameroon and eastern Nigeria (Collar and Stuart 1985). Known from the Dikome Balue area in the Rumpi Hills where it was recorded in small numbers by Serle (1954) and Stuart and Jensen (1986).

Mackinnon's Shrike Lanius mackinnoni. Fairly common in villages of the Rumpi Hills. 
Bocage's Akalat Sheppardia bocageit. This species was somewhat uncommon in RHFR. Recorded between 1,000 and 1,350 m.

White-bellied Robin-chat Cossyphicula robertit (RDB candidate). Fairly uncommon in RHFR and NAFR. A bird of primary and secondary forest which was found between 1,100 and 1,300 $\mathrm{m}$.

Mountain Robin-chat Cossypha isabellaet (RDB candidate). This thrush is known only from the montane forests of western Cameroon and south-eastern Nigeria (Keith et al. 1992). Common in RHFR between 1,100 and $1,650 \mathrm{~m}$ in primary and secondary forest.

Orange Ground-thrush Turdus gurneyi (Zoothera gurneyi crossleyi)t. In March 1992 P.R. tape-recorded two singing males at 1,650 m in RHFR. In April two singing males were heard at $1,100 \mathrm{~m}$ in NAFR. Identifications of recordings were made by C. Chappuis (in litt. 1993). Stuart and Jensen (1986) reported the species from Dikome Balue.

Grey-breasted Illadopsis Illadopsis poliothorax (RDB candidate). Fairly uncommon in primary and secondary forest in RHFR between 1,100 and 1,700 $\mathrm{m}$.

White-throated Mountain-babbler Lioptilis gilbertit (Threatened). Although given the global category "Rare" in Collar and Stuart (1985), it is fairly common in RHFR between 1,150 and 1,650 $\mathrm{m}$. Stuart and Jensen (1986) reported it as limited to tall mature forest, but P.R. once found a flock in a narrow strip of secondary forest in a farm, and on two other occasions birds were located in young secondary forest, though never far from mature forest. Groups of up to 20 were observed, the previous highest having been 12 (Serle 1950, Elgood 1982, Stuart and Jensen 1986). It has a very restricted distribution in montane areas of western Cameroon and eastern Nigeria and is not known from Mt Cameroon, Mt Manenguba or the Bamenda highlands (Hall and Moreau 1970, Louette 1981).

Blackcap Sylvia atricapilla. Recorded by Stuart (1986) at Dikome Balue.

Black-capped Woodland Warbler Phylloscopus herbertit (RDB candidate). This montane forest species is fairly common in RHFR in primary and secondary forest between 1,100 and $1,650 \mathrm{~m}$. It was also recorded in NAFR between 1,050 and 1,250 m. Only known from western Cameroon, Bioko (Fernando Po) and eastern Nigeria (Hall and Moreau 1970).

Green Longtail Urolais epichlorat (RDB candidate). Endemic to the montane forests of western Cameroon, Bioko (Fernando Po) and eastern Nigeria (Hall and Moreau 1970). Common in RHFR in primary and secondary forest and forest edge between 1,050 and 1,650 m. In early March P.R. observed a pair of adults feeding a juvenile. 
Black-throated Apalis Apalis jacksonit. Uncommon in RHFR. Stuart and Jensen's (1986) record of four individuals in March 1984 represented the first for the Rumpi Hills. P.R. recorded a total of 11 birds in RHFR in November 1991 and March 1992 between 1,100 and 1,500 m, in primary and secondary forest and second growth with tall trees. In early March a pair of adults were observed feeding a juvenile, indicating they had bred some time during the dry season.

Masked Apalis Apalis binotata*. P.R. recorded this species in RHFR.

Grey Apalis Apalis cinereat. Common in primary and secondary forest in RHFR from 1,100 to $1,650 \mathrm{~m}$, and common in NAFR above $1,000 \mathrm{~m}$.

Black-faced Rufous Warbler Bathmocercus rufus*. Common in RHFR in primary and secondary forest undergrowth above $1,000 \mathrm{~m}$. Although not considered a true montane species by Stuart and Jensen (1986), it is unknown from lowland areas in Korup and the Southwest Province of Cameroon.

White-tailed Warbler Camaroptera lopesit (RDB candidate). This species was fairly common in RHFR in primary and secondary forest undergrowth between 1,150 and 1,650 m. In early March 1992 P.R. observed a male carrying food. The species is limited to the montane forests of western Cameroon, eastern Nigeria and Bioko (Fernando Po) (Hall and Moreau 1970).

Dusky Flycatcher Muscicapa adustat. This species seems rare in the Rumpi Hills, but it is possible that it is overlooked. P.R. found only two birds during surveys in RHFR, one at $1,450 \mathrm{~m}$ in primary forest and the other at $1,200 \mathrm{~m}$ in secondary forest. Stuart and Jensen (1986) also considered it rare.

Yellow-bellied Hyliota Hyliota flavigaster. Uncommon in farms at Dikome Balue in the Rumpi Hills in November 1991.

Southern Yellow-bellied Flycatcher Hyliota australis. Serle (1965) collected one individual near Dikome Balue. The record is noteworthy as the species chiefly occurs in eastern and south-eastern Africa.

West African Batis Batis occulta*. This is a rare, recently split species which is known only from a few locations from Liberia to southern Cameroon (Lawson 1984, 1986). In Cameroon it was previously known only from Bitye and Ebolowa in the South Province (Louette 1981a). P.R. observed a pair in RHFR outside Dikome Balue in March 1992, building a nest at 1,150 $\mathrm{m}$ in an area of thick second growth with scattered trees. On several occasions the male sang a quiet high-pitched "see-see-see-see-see-see". This record represents the first for the Southwest Province and, apparently, the fifth for Cameroon. According to Lawson (1984) it is the only Batis in the forests of Cameroon.

Black-necked Wattle-eye Platysteira chalybea*. Uncommon in RHFR, where it was recorded between 1,000 and $1,350 \mathrm{~m}$ in primary and secondary forest. 
White-bellied Flycatcher Trochocercus albiventrist (RDB candidate). This montane flycatcher is fairly common in primary and secondary forest between 1,200 and $1,650 \mathrm{~m}$ in RHFR.

White-breasted Tit Parus albiventris. P.R. recorded this species at Nguti on 12 September 1992. There are very few records in the Southwest Province, but Serle (1950) mentioned observing small flocks at Mt Manenguba.

Ursula's Mouse-coloured Sunbird Nectarinia ursulaet (Near-threatened). This species is endemic to the montane forests of western Cameroon and Bioko (Fernando Po) (Hall and Moreau 1970). In RHFR it is fairly common in primary and secondary montane forest between 1,150 and 1,650 m. It was also recorded at NAFR in primary forest above $1,000 \mathrm{~m}$, where it was among the commonest birds.

Cameroon Blue-headed Sunbird Nectarinia oritist (RDB candidate). The species is found only in the montane forests of western Cameroon, eastern Nigeria and Bioko (Fernando Po) (Hall and Moreau 1970). Common in primary and secondary forest in RHFR between 1,100 and 1,650 m. In early November 1991 P.R. observed a bird building a nest and in early March 1992 two immatures were mist-netted.

Northern Double-collared Sunbird Nectarinia preussit. A fairly common montane species in RHFR, found in primary forest and forest edge between 1,200 and $1,650 \mathrm{~m}$.

Splendid Sunbird Nectarinia coccinogaster. Fairly common in second growth and farms in the vicinity of Dikome Balue in the Rumpi Hills.

Oriole Finch Linurgus olivaceust. A fairly uncommon montane species of RHFR, recorded between 1,000 and $1,550 \mathrm{~m}$ in secondary growth and forest clearings.

Red-faced Crimson-wing Cryptospiza reichenoviit. A fairly common montane species in the RHFR area $(1,000-1,550 \mathrm{~m})$, found in thick undergrowth of primary and secondary forests, but commonest in secondary growth.

Dark-backed Weaver Ploceus bicolor*. Common in primary and secondary forest and farms above $1,000 \mathrm{~m}$ in the Rumpi Hills. One bird was seen with nest material in early November 1991 in RHFR.

Black-billed Weaver Ploceus melanogastert. P.R. found this montane species somewhat uncommon in RHFR, in primary and secondary forests between 1,100 and $1,650 \mathrm{~m}$.

Brown-capped Weaver Ploceus insignist. This species is rather uncommon in RHFR and nearby areas, in primary and secondary montane forest and forest edge between 1,100 and 1,300 m. In early March 1992 an immature was seen being fed by an adult. 
Fire-crowned Bishop Euplectes hordeaceus. Known from areas of tall grass around villages and roadsides. Recorded at Nguti and along the road south to Kumba and west of Kumba, just outside of the KPA.

Yellow-mantled Widowbird Euplectes macrourus. Recorded in grassy areas at Nguti. Found just outside of the KPA between Ekondo Titi and Kumba, and between Kumba and Nguti.

Waller's Chestnut-winged Starling Onycognathus wallerit. A common bird of montane primary and secondary forest and farms in RHFR. P.R. recorded 45 birds in one day, a number much higher than that reported by Stuart and Jensen (1986), who had a daily high of 15 individuals per observer.

\section{Discussion and recommendations}

\section{Korup's importance at the continental level}

Our knowledge of the avifauna of Korup has increased greatly in the past three years, but it is by no means complete. In the context of African forests, however, Korup is already among the best-known sites, as few areas have been studied in detail. KNP is better known than the much larger KPA, although there are still parts of KNP which need additional attention.

A total of 390 species of bird are known to occur in KNP and KPA. Of this total, 327 are known from KNP and 63 only from the KPA, outside KNP. Many additional species will probably be recorded in the future (Appendix 2). Using the taxonomic scheme we followed (see Methods), a total of 50 families of bird are known from KNP/KPA. The most diverse groups in Korup area are the subfamilies Muscicapinae and Sylviinae, which are represented by 34 and 28 species respectively. Other diverse groups in KNP/KPA are the families Pycnonotidae with 25 species, Accipitridae with 22 species, and Nectariniidae and Ploceidae with 21 species each.

Dejaifve (1991) used data from Thiollay (1985) and Dejaifve (1989) to compare Korup's lowland forest bird diversity with diversity at other African lowland forest sites. Only those judged to be "true lowland rainforest birds" (Thiollay 1985) were considered, thereby excluding Palearctic and intra-African migrants and resident non-forest species, and allowing a more accurate appraisal of relative forest bird diversity. However, since the preparation of Dejaifve (1991) many new species have been added to the KNP/KPA list. The species totals for true lowland forest species are now as follows: Makokou in north-eastern Gabon 250 species (Brosset and Erard 1986), Taï National Park in south-western Ivory Coast 242 (Thiollay 1985, M. Gartshore in litt. 1993), Korup National Park and Project Area 233 (this study), Ituri Forest in eastern Zaire 226 (Dejaifve 1989), and Kouilou basin in Congo 210 (Dowsett-Lemaire and Dowsett 1991).

Korup thus currently ranks third among these sites in true lowland forest bird diversity. This is a high total given the fact that two of these sites (Makokou and Ituri) are much larger than KNP/KPA, and two (Makokou again and Tai) have been or are locations of long-term ornithological research. It is believed that, with additional research, the true lowland forest species total for Korup 
may approximate to that of Makokou in Gabon, although the species total for Ituri is certainly incomplete (P.A.D.). It should be noted that included in the above analysis were several true lowland forest species not listed in Thiollay (1985) but mentioned as forest species by Elgood (1982), Moreau (1966) and Fry et al. (1988), namely: Yellow-footed Honeyguide Melignomon eisentrauti, Forest Swallow Hirundo fuliginosa, Petit's Cuckoo-shrike Campephaga petiti, Banded Prinia Prinia bairdii, Buff-throated Apalis Apalis rufogularis, Black-faced Rufous Warbler Bathmocercus rufus, Kemp's Longbill Macrosphenus kempi, West African Batis Batis occulta, Black-necked Wattle-eye Platysteira chalybea and Black-necked Weaver Ploceus nigricollis.

Korup's forest bird diversity is increased by the addition of montane forest bird species found in RHFR and NAFR. Our surveys there added one species, Cameroon Olive Pigeon Columba sjostedi, to the list of 35 classified and documented for the Rumpi Hills by Jensen and Stuart (1986). This brings the total number of true montane (36) and lowland (233) forest species found in $\mathrm{KNP} / \mathrm{KPA}$ to 269, a number unequalled in any area studied thus far in West Africa.

\section{Conservation of forest birds in korup}

The lowland and montane forests of KNP/KPA are very important to the conservation of African forest birds. Four species found in the Korup area are considered "threatened" by the ICBP/IUCN and another four are considered "nearthreatened" (Table 2), while at least 40 of Korup's bird species were candidates for threatened status (Appendix 3) (Collar and Stuart 1985). Owing to habitat destruction in some areas and the limited ranges of certain species, some of the species originally listed as RDB candidates are likely future additions to the near-threatened list.

A number of Korup's bird species have very limited ranges in Africa, making their occurrence in the area of high conservation importance. Twelve of Korup's 36 montane forest bird species are found only in the montane forests of western Cameroon, eastern Nigeria and Bioko (Fernando Po). Two of these (White-throated Mountain-babbler Lioptilis gilberti and Green-breasted Bushshrike Malaconotus gladiator) are not found on Bioko and have very limited ranges in Cameroon. In addition, a number of lowland forest species have limited ranges in Africa (e.g. Brown Nightjar Caprimulgus binotatus, Forest Swallow Hirundo fuliginosa, Black-eared Ground-thrush Zoothera cameronensis, Redheaded Rockfowl Picathartes oreas and Rachel's Malimbe Malimbus racheliae).

The NAFR and RHFR (including adjacent highland areas in the KPA) are especially important for the conservation of montane forest birds. The diversity of montane bird species in these areas is high. A total of 36 montane species are known from RHFR and eight of these have also been recorded in NAFR. Many of them, including "Threatened" and "near-threatened" species, are quite common in these forest reserves. Moreover, as mentioned previously, 12 species are endemic to montane forest areas of western Cameroon, eastern Nigeria and Bioko. Considering the fact that much of the montane forest in western Cameroon has been cleared for agriculture and grazing, the significance of RHFR and NAFR for the conservation of montane forest birds becomes espe- 
Table 2. Threatened and near-threatened birds in KNP/KPA (Collar and Stuart 1985).

White-naped Pigeon Columba albinucha $(\mathrm{n}-\mathrm{t})$

Yellow-footed Honeyguide Melignomon eisentrauti (K)

Cameroon Montane Greenbul Andropadus montanus (n-t)

Grey-headed Greenbul Phyllastrephus poliocephalus (n-t)

Green-breasted Bush-shrike Malaconotus gladiator (R)

White-throated Mountain-babbler Lioptilis gilberti (R)

Red-headed Rockfowl Picathartes oreas ( $R$ )

Ursula's Mouse-coloured Sunbird Nectarinia ursulae (n-t)

Of the four threatened species listed above, three are in the category Rare (R), and one is Insufficiently Known (K).

cially evident. The White-throated Mountain-babbler provides a good example of the conservation importance of RHFR. This species is classified as "Rare" by Collar and Stuart (1985), but it is fairly common in RHFR. However, outside the Rumpi Hills it is known only from Mt Kupe, Mt Nlonako, Foto (near Dschang) and the Obudu Plateau in Nigeria (Stuart and Jensen 1986). It has not been found on Mt Cameroon, Mt Manenguba or in the Bamenda Highlands (Hall and Moreau 1970, Louette 1981a).

At the moment the Rumpi Hills and Nta Ali Forest Reserves lack management plans. We strongly suggest that both areas, but especially RHFR, be given protection rather than production status. In RHFR this would result in the protection of an altitudinal forest gradient from $80 \mathrm{~m}$ to $1,650 \mathrm{~m}$, thus preserving in a relatively small area one of the richest localities for montane and lowland forest bird species in Africa. If the high diversity of birds in these forests parallels that of other fauna and flora, a very significant amount of biodiversity could be protected by such a decision. However, if protection status is not feasible and either RHFR or NAFR is opened to logging companies, their activities should be restricted to the lowland areas of these reserves. This would allow for the better protection of montane flora and fauna, very little of whose forest habitat, despite the high levels endemism involved, is otherwise currently conserved.

\section{Recommendations for future ornithological research in Korup}

The natural histories of African forest birds are in general very poorly known. This provides a nearly endless array of topics for researchers to study. At this point, however, it is perhaps more important for biologists and park managers to continue studies of the avian diversity in KNP/KPA. For this reason, most of the ornithological research proposed involves additional surveying of the Korup area.

To begin with, further bird survey work is needed in NAFR. There are certainly several other montane forest birds species to be discovered there, and perhaps some of the western Cameroon endemics. New information would be important as many of these montane species have limited distributions. In addition, the slopes of Mt Nta Ali could provide excellent habitat for the rare Picathartes oreas.

The Ejagham Forest Reserve has to our knowledge not received the attention of biologists. Bird surveys there would probably reveal an avifauna similar to 
that found in KNP, but Lake Ejagham should support waterbirds not easily found in KNP, and perhaps new species for Korup.

Other areas which are in need of survey work are Mt Yuhan, near Ekundu Kundu in the south of KNP, and the extreme south of the KNP and KPA. One montane forest species (Lemon Dove Columba larvata) is known from Mt Yuhan and it is possible that others occur there. Swamp forest and mangrove edge in the extreme south of KNP and KPA has not been surveyed. Although much of this land is rather inaccessible, surveys should turn up interesting results.

An extensive survey of Picathartes oreas in KNP/KPA would be of conservation interest. This species is considered "Rare" by the ICBP/IUCN (Collar and Stuart 1985) and occurs locally in south-east Nigeria, Cameroon, Equatorial Guinea (mainland and Bioko) and Gabon (see Ash 1991).

Researchers interested in forest understorey bird ecology are encouraged to continue studies of birds banded at the Ikenge Research Station in the north of KNP. Over 700 birds were banded in 1991 and 1992 at IRS, providing an excellent opportunity for the study of breeding phenology, biometrics, longevity and bird movements. Additional information on birds banded at IRS is best obtained through P.R. Another interesting project would be to compare understorey bird species composition between the north and south of KNP.

\section{Acknowledgements}

Many people have been of great assistance to us during this study. We would like to thank James Powell and Maureen Durkin-Powell for their support, generosity and friendship; Evelyne Laurent for her companionship, her help with mist-netting birds at the Ikenge Research Station and for providing comments on this report; Steve and Sue Gartlan for always being so welcoming at their home in Douala and for going out of their way on many occasions to provide assistance; Bill Weber, Martha Schwartz, Mary Pearl, Amy Vedder, Geoff Mellor, John and Terese Hart, and Lisa Molloy at WCS in New York for their helpfulness in ways too numerous to mention. A number of individuals kindly helped with reviewing various drafts of this manuscript, including James Powell, Elizabeth Graham, Paul Rodewald Jr and Amanda Dumin. Extensive comments from Françoise Dowsett-Lemaire were especially helpful. Stuart Keith gave advice and encouragement during the writing of this manuscript. Claude Chappuis provided assistance in the identification of unknown bird vocalizations. Simon Bearder and Paul Honess shared tape-recordings of birds from their research in Korup. Phil Agland, Jane Thomas and Mary Gartshore provided valuable unpublished information. We warmly thank Okon Felix, Philip Hium, and Ndip Denis for their assistance in the field and their friendship on uncountable evenings at the Ikenge Research Station.

Financial support for this study was provided by NYZS/The Wildlife Conservation Society and the U.S. Agency for International Development (P.R. and P.A.D.), and World Wide Fund for Nature (A.A.G.). 
Appendix 1. Gazetteer of localities mentioned in text.

\begin{tabular}{|c|c|c|}
\hline Bakebe & $5^{\circ} 34^{\prime} \mathrm{N} 9^{\circ} 35^{\prime} \mathrm{E}$ & $160 \mathrm{~m}$ \\
\hline Bakumba & $5^{\circ} 18^{\prime} \mathrm{N}_{9}^{\circ} \mathrm{O}^{\prime} \mathrm{E}$ & $240 \mathrm{~m}$ \\
\hline Bamenda & $5^{\circ} 55^{\prime} \mathrm{N} 10^{\circ} 10^{\prime} \mathrm{E}$ & $1,520 \mathrm{~m}$ \\
\hline Baro & $5^{\circ} 17^{\prime} \mathrm{N} 9^{\circ} 12^{\prime} \mathrm{E}$ & $240 \mathrm{~m}$ \\
\hline Bera & $5^{\circ} 20^{\prime} \mathrm{N} 8^{\circ} 59^{\prime} \mathrm{E}$ & $320 \mathrm{~m}$ \\
\hline Bioko (Fernando Po) & $3^{\circ} 30^{\prime} \mathrm{N} 8^{\circ} 30^{\prime} \mathrm{E}$ & $0-3,008 \mathrm{~m}$ \\
\hline Cape Debundsha & $4^{\circ} \mathrm{O} 5^{\prime} \mathrm{N} 9^{\circ} \mathrm{Oo}^{\prime} \mathrm{E}$ & $10 \mathrm{~m}$ \\
\hline Dikome Balue & $4^{\circ} 55^{\prime} \mathrm{N} 9^{\circ} 16^{\prime} \mathrm{E}$ & $1,150 \mathrm{~m}$ \\
\hline Ekondo Titi & $4^{\circ} 35^{\prime} \mathrm{N} 9^{\circ} \mathrm{O}^{\prime} \mathrm{E}$ & $80 \mathrm{~m}$ \\
\hline Ekundu Kundu & $5^{\circ} \circ 8^{\prime} \mathrm{N} 8^{\circ} 53^{\prime} \mathrm{E}$ & $100 \mathrm{~m}$ \\
\hline Erat & $5^{\circ} \mathrm{O}^{\prime} \mathrm{N} 8^{\circ} 45^{\prime} \mathrm{E}$ & $70 \mathrm{~m}$ \\
\hline Esukutang & $5^{\circ} 23^{\prime} \mathrm{N} 9^{\circ} \mathrm{OO}{ }^{\prime} \mathrm{E}$ & $220 \mathrm{~m}$ \\
\hline Foto & $5^{\circ} 31^{\prime} \mathrm{N} 9^{\circ} 55^{\prime} \mathrm{E}$ & $1,500 \mathrm{~m}$ \\
\hline Ikenge & $5^{\circ} 16^{\prime} \mathrm{N} 9^{\circ} 06^{\prime} \mathrm{E}$ & $240 \mathrm{~m}$ \\
\hline Ikenge Research Station (IRS) & $5^{\circ} 16^{\prime} \mathrm{N} 9^{\circ} \mathrm{O} 7^{\prime} \mathrm{E}$ & $240 \mathrm{~m}$ \\
\hline Ikpan Block & $5^{\circ} \mathrm{O} 5^{\prime} \mathrm{N} 8^{\circ} 40^{\prime} \mathrm{E}$ & $<100 \mathrm{~m}$ \\
\hline Kumba & $4^{\circ} 37^{\prime} \mathrm{N} 9^{\circ} 27^{\prime} \mathrm{E}$ & $200 \mathrm{~m}$ \\
\hline Lake Ejagham & $5^{\circ} 45^{\prime} \mathrm{N} 9^{\circ} \mathrm{Oo}^{\prime} \mathrm{E}$ & $80 \mathrm{~m}$ \\
\hline Limbe (formerly Victoria) & $4^{\circ} \mathrm{Oo}^{\prime} \mathrm{N} 9^{\circ} 12^{\prime} \mathrm{E}$ & $10 \mathrm{~m}$ \\
\hline Madie-3 & $4^{\circ} 59^{\prime} \mathrm{N} 9^{\circ} 13^{\prime} \mathrm{E}$ & $1,150 \mathrm{~m}$ \\
\hline Mamfe & $5^{\circ} 45^{\prime} \mathrm{N} 9^{\circ} 19^{\prime} \mathrm{E}$ & $80 \mathrm{~m}$ \\
\hline Manyemen & $5^{\circ} 13^{\prime} \mathrm{N} 9^{\circ} 24^{\prime} \mathrm{E}$ & $320 \mathrm{~m}$ \\
\hline Massaka & $4^{\circ} 50^{\prime} \mathrm{N} 9^{\circ} 15^{\prime} \mathrm{E}$ & $720 \mathrm{~m}$ \\
\hline Mbonge & $4^{\circ} 32^{\prime} \mathrm{N} 9^{\circ} 06^{\prime} \mathrm{E}$ & $70 \mathrm{~m}$ \\
\hline Mundemba & $4^{\circ} 56^{\prime} \mathrm{N} 8^{\circ} 53^{\prime} \mathrm{E}$ & $90 \mathrm{~m}$ \\
\hline Mt Cameroon & $4^{\circ} 12^{\prime} \mathrm{N} 9^{\circ} 11^{\prime} \mathrm{E}$ & $4,070 \mathrm{~m}$ \\
\hline Mt Kupe (Nyassosso) & $4^{\circ} 45^{\prime} \mathrm{N} 9^{\circ} 40^{\prime} \mathrm{E}$ & $2,050 \mathrm{~m}$ \\
\hline Mt Manenguba & $5^{\circ} \mathrm{O} 5^{\prime} \mathrm{N} 9^{\circ} 5^{\circ} \mathrm{E}$ & $2,396 \mathrm{~m}$ \\
\hline Mt Nlonako & $4^{\circ} 53^{\prime} \mathrm{N} 9^{\circ} 55^{\prime} \mathrm{E}$ & $1,825 \mathrm{~m}$ \\
\hline Mt Nta Ali & $5^{\circ} 36^{\prime} \mathrm{N} 9^{\circ} 30^{\prime} \mathrm{E}$ & $1,266 \mathrm{~m}$ \\
\hline Mt Yuhan & $5^{\circ} 10^{\prime} \mathrm{N} 8^{\circ} 5^{\prime} \mathrm{E}$ & $1,079 \mathrm{~m}$ \\
\hline Ndian & $4^{\circ} 55^{\prime} \mathrm{N} 8^{\circ} 50^{\prime} \mathrm{E}$ & $70 \mathrm{~m}$ \\
\hline Ndoi (Konye) & $4^{\circ} 55^{\prime} \mathrm{N} 9^{\circ} 30^{\prime} \mathrm{E}$ & $300 \mathrm{~m}$ \\
\hline Nfainchang & $5^{\circ} 37^{\prime} \mathrm{N} 9^{\circ} 30^{\prime} \mathrm{E}$ & $200 \mathrm{~m}$ \\
\hline Nguti & $5^{\circ} 21^{\prime} \mathrm{N} 9^{\circ} 25^{\prime} \mathrm{E}$ & $240 \mathrm{~m}$ \\
\hline Oban Hills Forest Reserve & $5^{\circ} 25^{\prime} \mathrm{N} 8^{\circ} 20^{\prime} \mathrm{E}$ & $1,000 \mathrm{~m}$ \\
\hline Obudu Plateau (Nigeria) & $6^{\circ} 40^{\prime} \mathrm{N} 9^{\circ} 10^{\prime} \mathrm{E}$ & $1,500 \mathrm{~m}$ \\
\hline Osirayib & $5^{\circ} 17^{\prime} \mathrm{N} 9^{\circ} 22^{\prime} \mathrm{E}$ & $320 \mathrm{~m}$ \\
\hline Rio del Rey & $4^{\circ} 40^{\prime} \mathrm{N} 8^{\circ} 40^{\prime} \mathrm{E}$ & $\mathrm{om}$ \\
\hline Woné & $5^{\circ} \mathrm{O}^{\prime} \mathrm{N} 9^{\circ} 23^{\prime} \mathrm{E}$ & $480 \mathrm{~m}$ \\
\hline
\end{tabular}




\section{Appendix 2. List of hypothetical species for KNP/KPA}

The following is a partial list of species which are likely occur in KNP or KPA. Observers should take note of these species and be aware of their possible occurrence. Of the species listed below nearly all have been recorded near KNP/KPA or elsewhere in the Southwest Province of Cameroon. Other species are simply expected to occur because their ranges or migratory paths should include KNP/KPA. A few species listed here have already been reported from KNP, but without convincing details. Many birds which have been recorded in the KPA are likely candidates for the KNP list.

Little Bittern Ixobrychus minutus

White-backed Night-heron Gorsachius leuconotus

Western Reef Heron Egretta gularis

Yellow-billed Egret Egretta intermedia

Goliath Heron Ardea goliath

Abdim's Stork Ciconia abdimii

Olive Ibis Bostrychia olivacea

Ayre's Hawk-eagle Hieraaetus dubius

Buff-spotted Flufftail Sarothrura elegans

Red-chested Flufftail Sarothrura rufa

Sandy Scops-owl Otus icterorhynchus

Pel's Fishing-owl Scotopelia peli

Red-chested Owlet Glaucidium tephronotum

Black-shouldered Nightjar Caprimulgus nigriscapularis

Plain Nightjar Caprimulgus inornatus

European Nightjar Caprimulgus europaeus

Narina's Trogon Apaloderma narina

Little Bee-eater Merops pusillus

Double-toothed Barbet Lybius bidentatus

Wahlberg's Honeybird Prodotiscus regulus

Thick-billed Honeyguide Indicator conirostris

Willcocks's Honeyguide Indicator willcocksi

Fire-bellied Woodpecker Dendropicos pyrrhogaster

Common Sand Martin Riparia riparia

Long-billed Pipit Anthus similis

Plain-backed Pipit Anthus leucophrys

Purple-throated Cuckoo-shrike Campephaga quiscalina

Eastern Wattled Cuckoo-shrike Campephaga oriolina

Yellow-throated Leaf-love Chlorocichla flavicollis soror

Grey-headed Bristlebill Bleda canicapilla

Yellow-fronted Penduline Tit Remiz flavifrons

Yellow-throated Nicator Nicator vireo

Sooty Boubou Laniarius leucorhynchus

Fiery-breasted Bush-shrike Malaconotus cruentus

Icterine Warbler Hippolais icterina

Red-cheeked Wattle-eye Platysteira blissetti

Slender-billed Weaver Ploceus pelzelni 
Appendix 3. RDB candidates considered for threatened status in Africa (Collar and Stuart 1985) which have been recorded in KNP/KPA.

White-crested Tiger-heron Tigriornis leucolophus

Spot-breasted Ibis Bostrychia rara

Congo Serpent-eagle Dryotriorchis spectabilis

Long-tailed Hawk Urotriorchis macrourus

Cassin's Hawk-eagle Spizaetus africanus

Black Guineafowl Agelastes niger

Cameroon Olive Pigeon Columba sjostedt $i$

Maned Owl Jubula letti

Akun Eagle-owl Bubo leucostictus

Vermiculated Fishing-owl Scotopelia bouvieri

Chestnut-backed Owlet Glaucidium sjostedti

Bates's Nightjar Caprimulgus batesi

Brown Nightjar Caprimulgus binotatus

Black Spinetail Telacanthura melanopygia

Bates's Swift Apus batesi

Bare-cheeked Trogon Apaloderma aequatoriale

Brown-cheeked Hornbill Ceratogymna cylindricus

Yellow-casqued Wattled Hornbill Ceratogymna elata

Lyre-tailed Honeyguide Melichneutes robustus

Tullberg's Woodpecker Campethera tullbergi

Grey-headed Broadbill Smithornis sharpei

Forest Swallow Hirundo fuliginosa

Sjöstedt's Honeyguide Greenbul Baeopogon clamans

Cameroon Olive Greenbul Phyllastrephus poensis

Fülleborn's Black Boubou Laniarius fuelleborni

White-bellied Robin-chat Cossyphicula roberti

Mountain Robin-chat Cossypha isabellae

Black-eared Ground-thrush Zoothera cameronensis

Grey Ground-thrush Zoothera princei

Grey-breasted Illadopsis Malacocincla poliothorax

Black-capped Woodland Warbler Phylloscopus herberti

Green Longtail Epichlora urolais

White-tailed Warbler Camaroptera lopesi

Kemp's Longbill Macrosphenus kempi

Olivaceous Flycatcher Muscicapa olivascens

Violet-backed Flycatcher Hyliota violacea

White-spotted Wattle-eye Platysteira tonsa

White-bellied Flycatcher Trochocercus albiventris

Cameroon Blue-headed Sunbird Nectarinia oritis

Rachel's Malimbe Malimbus racheliae 


\section{References}

Addison, J., Cashman, P., Counsell, D., Thompson, T. and Wolton, R. (1988) A brief survey of birds, bats, and other small mammals and water beetles in Korup N.P., Cameroon by a visiting British team in 1988. Unpublished report.

Anon. (1989) Project Raleigh Bird Survey in Korup National Park, Phases 1-3. Unpublished report.

Ash, J. S. (1990) Additions to the avifauna of Nigeria, with notes on distributional changes and breeding. Malimbus 11: 104-116.

Ash, J. S. (1991) The Grey-necked Picathartes Picathartes oreas and Ibadan Malimbe Malimbus ibadanensis in Nigeria. Bird Conserv. Internatn. 1: 93-106.

Ash, J. S., Dowsett, R. J. and Dowsett-Lemaire, F. (1989) New ornithological distribution records from eastern Nigeria. Tauraco Research Report 1: 13-27.

Bannerman, D. A. (1930-1936) The birds of tropical West Africa, 2-4. London: Crown Agents.

Brosset, A. and Erard, C. (1986) Les oiseaux des régions forestières du nord-est du Gabon, 1. Paris: Société Nationale de Protection de la Nature.

Brown, L. H., Urban, E. K. and Newman, K. (1982) The birds of Africa, 1. London: Academic Press.

Collar, N. J. and Stuart S. N. (1985) Threatened birds of Africa and related islands: the ICBP/IUCN red data book. Cambridge: International Council for Bird Preservation and International Union for Conservation of Nature and Natural Resources.

Dejaifve, P. A. (1989) Esquisse de l'avifaune de l'Ituri, N.E. Zaire. Unpublished manuscript.

Dejaifve, P. A. (1991) Outline of the Avifauna in Korup National Park, Southwest Province, Cameroon. Wildlife Conservation International Report, New York Zoological Society (unpublished manuscript).

Dowsett-Lemaire, F. (1992) On the vocal behaviour and habitat of the Maned Owl Jubula lettii in southwestern Congo. Bull. Brit. Orn. Club 112: 213-218.

Dowsett-Lemaire, F. and Dowsett, R. J. (1991) The avifauna of the Kouilou basin in Congo. Tauraco Research Report 4: 189-239.

Eisentraut, M. (1956) Notizen über einige Vögel des Kamerungebirges. J. Orn. 97: 291300.

Eisentraut, M. (1963) Die Wirbeltier des Kamerungebirges. Hamburg and Berlin: P. Parey.

Elgood, J. H. (1982) The birds of Nigeria. London: British Ornithologists' Union (Check-list 4).

Erard, C. (1977) Découverte du nid de Baeopogon clamans (Sjöstedt). Alauda 45: 271-277.

Fry, C. H., Keith, S. and Urban, E. K. (1988) The birds of Africa, 3. London: Academic Press.

Gartlan, S. G. (1984) The Korup Regional Mangement Plan: conservation and development in the Ndian division of Cameroon. Publication 25-106 of the Wisconsin Regional Primate Research Center, U.S.A.

Gartshore, M. E. (1984) Notes on the nesting of two little known species of bee-eaters in Cameroon. Malimbus 6: 95-96.

Gullick, T. H. (1987) List of birds seen in Korup National Park. Unpublished report.

Hall, B. P. and Moreau, R. E. (1962) A study of the rare birds of Africa. Bull Brit. Mus. (Nat. Hist.) Zool. 8: 313-378.

Hall, B. P. and Moreau, R. E. (1970) An atlas of speciation in African passerine birds. London: Trustees of the British Museum (Natural History).

Jensen, F. P. and Stuart, S. N. (1986) The origin and evolution of the Cameroon montane forest avifauna. Pp.28-37 in S. N. Stuart, ed. Conservation of Cameroon montane forests. Cambridge, U.K.: International Council for Bird Preservation. 
Karr, J. (1981) Surveying birds in the tropics. Stud. Avian Biol. 6: 548-553.

Keith, S., Urban, E. K., Fry, C. H. (1992) The birds of Africa, 4. London: Academic Press.

Lawson, W. J. (1984) The West African mainland forest dwelling population of Batis; a new species. Bull. Brit. Orn. Club 104(4): 144-146.

Lawson, W. J. (1986) Speciation in the forest-dwelling populations of the avian genus Batis. Durban Mus. Novit. 13(21): 285-304.

Louette, M. (1981a) The birds of Cameroon: an annotated check-list. Brussels: Verhandeling Wetenschappen, Jaargang 43, no. 163.

Louette, M. (1981b) A new species of Honeyguide from West Africa (Aves: Indicatoridae). Rev. Zool. Afr. 95: 131-135.

Mackenzie, P. (1979) Birds of the Calabar area. Malimbus 1: 47-55.

Ministry of Plan and Regional Development, with support from World Wide Fund for Nature, Commission of the European Communities and Overseas Development Natural Resources Institute (1989) Plan for developing the Korup National Park and its support zone. Republic of Cameroon, The Korup Project.

Moreau, R. E. (1966) The bird faunas of Africa and its islands. London and New York: Academic Press.

Morony, J. J., Bock, W. J., and Farrand, J. (1975) Reference list of the birds of the world. New York: American Museum of Natural History.

Serle, W. (1950) A contribution to the ornithology of the British Cameroons. Ibis 92: 343$376,602-638$.

Serle, W. (1954) A second contribution to the ornithology of the British Cameroons. Ibis 96: $47-80$.

Serle, W. (1959) Some breeding bird records of birds at Ndian, British Southern Cameroons. Nigerian Field 24: 76-79.

Serle, W. (1965) A third contribution to the ornithology of the British Cameroons. Ibis 107: 60-246.

Serle, W. (1981) The breeding season of birds in the lowland rainforest and in the montane forest of west Cameroon. Ibis 123: 62-74

Serle, W. and Morel, G. J. (1977) A field guide to the birds of West Africa. New York: Collins.

Smith, P. (1989) Bird survey of Korup and Mt Oku, Cameroon, 9-29 January 1989. Unpublished report.

Stuart, S. N. (1986) Records of other species of bird from western Cameroon. Pp.106129 in S. N. Stuart, ed. (1986) Conservation of Cameroon montane forests. Cambridge, U.K.: International Council for Bird Preservation.

Stuart, S. N. and Jensen, F. P. (1986) The status and ecology of montane forest bird species in western Cameroon. Pp.38-105 in S. N. Stuart, ed. (1986) Conservation of Cameroon montane forests. Cambridge, U.K.: International Council for Bird Preservation.

Suchel, J.-B. (1972) La répartition des pluies et les régimes pluviométriques au Cameroun. Yaoundé: Université Fédérale du Cameroun.

Thiollay, J. M. (1985) The West African forest avifauna: a review. Pp.171-186 in A. W. Diamond, ed. Conservation of tropical forest birds. Cambridge, U.K.: International Council for Bird Preservation (Techn. Publ. 4).

Thomas, D. W. (1986) Vegetation in the montane forests of Cameroon. Pp.20-27 in S. N. Stuart, ed. (1986) Conservation of Cameroon montane forests. Cambridge, U.K.: International Council for Bird Preservation.

Thomas, J. (1991) Birds of the Korup National Park, Cameroon. Malimbus 13: 11-23.

Thomas, J. (in press) Birds of the Rio del Rey, Cameroon. Malimbus.

Tye, H. (1992) Reversal of breeding season by lowland birds at higher altitudes in western Cameroon. Ibis 134: 154-163.

Urban, E. K., Fry, C. H., Keith, S. (1986) The birds of Africa, 2. London: Academic Press. 
White, C. M. N. (1960) A checklist of the Ethiopian Muscicapidae (Sylviinae). Part 1. Occas. Pap. Natn. Mus. S. Rhod. 3(24B): 399-430.

White, C. M. N. (1962a) A checklist of the Ethiopian Muscicapidae (Sylviinae). Parts 2 and 3. Occas. Pap. Natn. Mus. S. Rhod. 3(26B): 653-738.

White, C. M. N. (1962b) A revised checklist of African shrikes, orioles, drongos, starlings, crows, waxwings, cuckoo-shrikes, bulbuls, accentors, thrushes, and babblers. Lusaka: Government Printer.

White, C. M. N. (1963) A revised checklist of African flycatchers, tits, tree-creepers, sunbirds, white-eyes, honey-eaters, buntings, finches, weavers, and waxbills. Lusaka: Government Printer.

Zimmerman, D. A. (1972) The avifauna of Kakemega Forest, western Kenya, including a bird population study. Bull. Amer. Mus. Nat. Hist. 149(3).

\section{PAUL G. RODEWALD}

NYZS/The Wildlife Conservation Society, Bronx, NY 10460-1099, U.S.A. (Current address: Department of Biological Sciences, University of Arkansas, SCEN 601, Fayetteville, AR 72701, U.S.A.)

\section{PIERRE-ANDRE DEJAIFVE}

Laboratoire Arago, Université Paris VI, F-66650 Banyuls-sur-Mer, France

\section{ARTHUR A. GREEN}

World Wide Fund for Nature, B.P. 2417, Douala, Cameroon 